\title{
An Archaeological and Geomorphological Investigation of Northrup Park, Boerne, Kendall County, Texas
}

David L. Nickels

Follow this and additional works at: https://scholarworks.sfasu.edu/ita

Part of the American Material Culture Commons, Archaeological Anthropology Commons, Environmental Studies Commons, Other American Studies Commons, Other Arts and Humanities Commons, Other History of Art, Architecture, and Archaeology Commons, and the United States History Commons

Tell us how this article helped you.

This Article is brought to you for free and open access by the Center for Regional Heritage Research at SFA ScholarWorks. It has been accepted for inclusion in Index of Texas Archaeology: Open Access Gray Literature from the Lone Star State by an authorized editor of SFA ScholarWorks. For more information, please contact cdsscholarworks@sfasu.edu. 
An Archaeological and Geomorphological Investigation of Northrup Park, Boerne, Kendall County, Texas

\section{Creative Commons License}

\section{(c) (1) (8)}

This work is licensed under a Creative Commons Attribution-NonCommercial 4.0 International License 


\section{Archaeological Survey Report, No. 247 Center for Archaeological Research The University of Texas at San Antonio 1998}

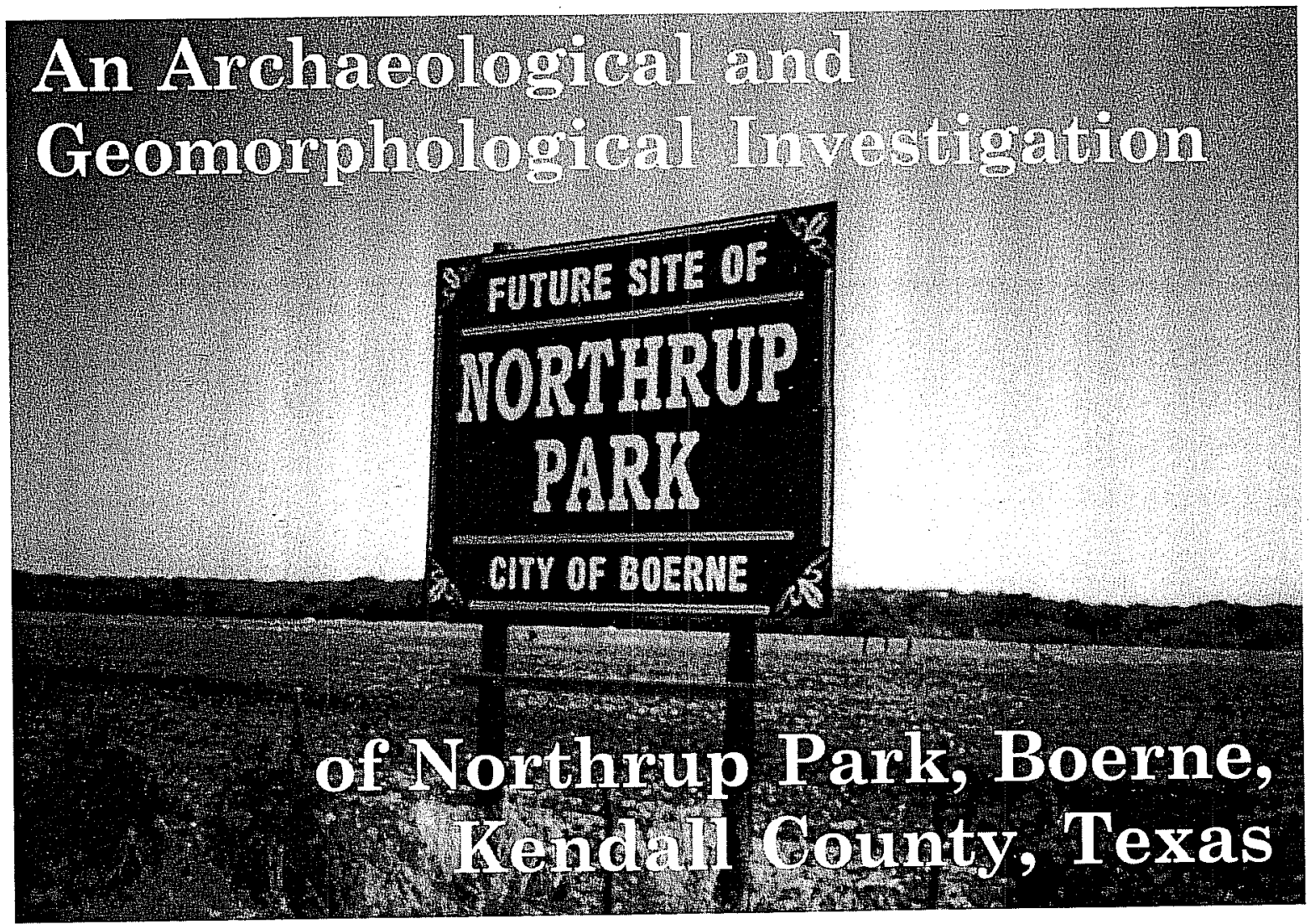

David L. Nickels

with contributions by

C. Britt Bousman and Thomas R. Hester 



\title{
An Archaeological and Geomorphological Investigation of Northrup Park, Boerne, Kendall County, Texas
}

\author{
David L. Nickels \\ with contributions by \\ C. Britt Bousman and Thomas R. Hester \\ Robert J. Hard and C. Britt Bousman \\ Principal Investigators
}

Texas Antiquities Permit Number 1670

Ccopyright

Center for Archaeological Research

The University of Texas at San Antonio

Archaeological Survey Report, No. 247

1998 
The following information is provided in accordance with the General Rules of Practice and Procedure, Chapter 41.11 (Investigative Reports), Texas Antiquities Committee:

1. Type of Investigation: Survey and limited subsurface testing

2. Project name: Northrup Park

3. County: Kendall

4. Principal Investigator: Robert J. Hard; co-Principal investigator: C. Britt Bousman

5. Name and location of sponsoring agency: City of Boerne, P.O. Box 1677, Boerne, Texas 78006-1677

6. Texas Antiquities Permit: No. 1670

7. Published by the Center for Archaeological Research, The University of Texas at San Antonio, 6900 North Loop 1604 West, San Antonio, Texas 78249-0658, 1998

A list of publications offered by the Center for Archaeological Research is available. Call (210) 458-4378; write to the Center for Archaeological Research, The University of Texas at San Antonio, 6900 N. Loop 1604 W., San Antonio, Texas 78249-0658; e-mail to car@lonestar.utsa.edu; or visit CAR's Web site at http://www.csbs.utsa.edu/ research/car/index.htm. 


\begin{abstract}
The Center for Archaeological Research (CAR) of The University of Texas at San Antonio contracted with the raw land planned for development as a city park in south Kendall County. The purpesting of 103 acres of identify archaeological sites visible on the surface and areas with County. The purpose of the survey was to sites were found and recorded. A plan of avoidance was recomm potential for buried sites. Seven prehistoric construction plan could not be altered to accommodate both the proposed archaeological sites. Therefore, with the concurrence of the The needs of the city and the avoidance of all the $41 \mathrm{KE} 143,41 \mathrm{KE} 144,41 \mathrm{KE} 145$, and $41 \mathrm{KE} 147$ were 100 -percent Historical Commission, 41KE141, 41KE142, were excavated at all but $41 \mathrm{KE} 143$. As the shovel tests revealed surface collected, and additional shovel tests Boerne be allowed to proceed with development of the park aled no cultural material, CAR recommends that the current project as planned; however, CAR recommends that further. Site $41 \mathrm{KE} 146$ will not be impacted by any future construction activities within the site boundaries.
\end{abstract}




\section{Contents}

i

iii

Abstract

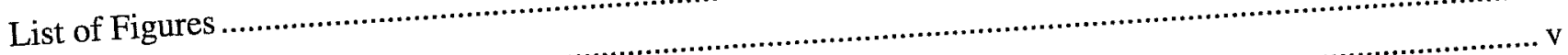

List of Tables

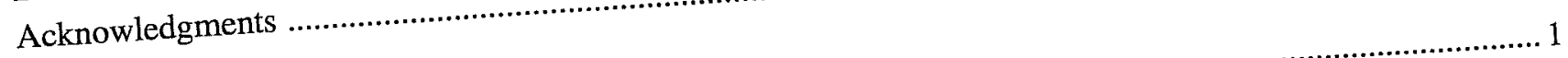

Acknowlen

Introduction

Project Area

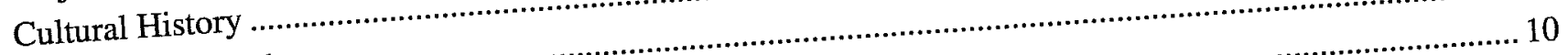

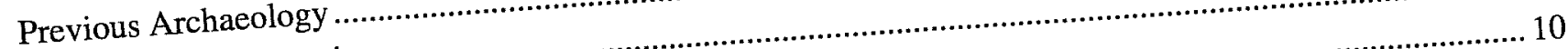

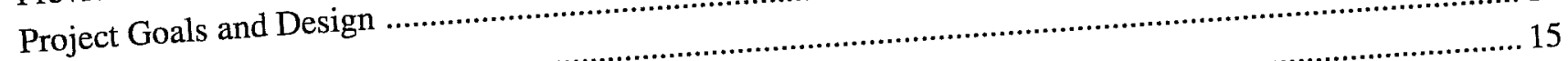

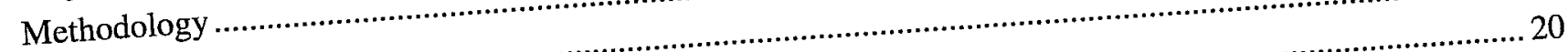

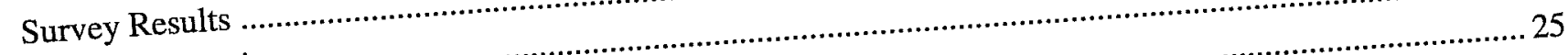

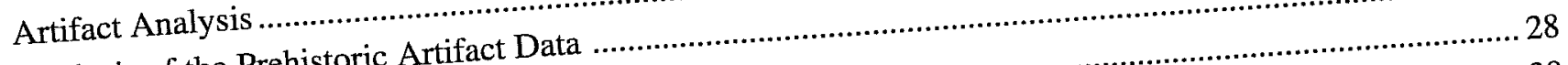

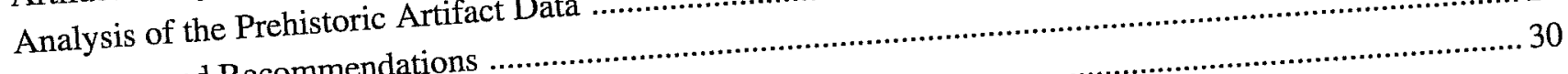

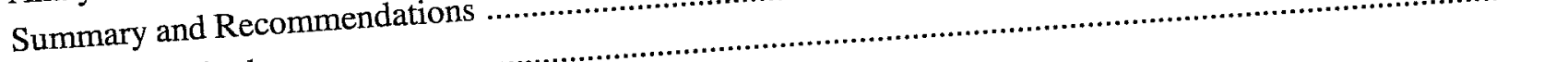

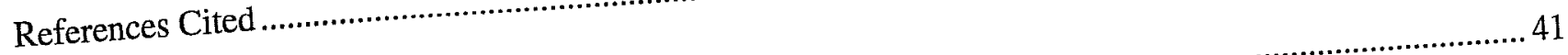

Appendix A: Chipped Stone Artifact Attributes .............. in South Central Kendall County

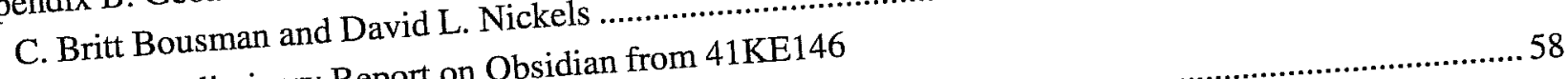

Appendix C: Preliminary Report on Obsidian from 41KE146

Thomas R. Hester 


\section{Figures}

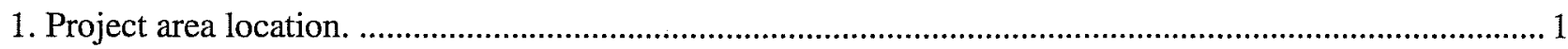

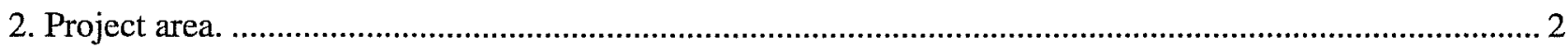

3. Shovel tests along unplowed terraces and bluff .......................................................................... 11

4. Sites, shovel tests, and backhoe trenches in the south 50 acres of the project area. ............................... 13

5. Planned construction of ball fields, pavilion, and pool in the project area. .......................................... 13

6. Shovel tests at $30-\mathrm{m}$ intervals in the south 50 acres of the project area. ............................................. 14

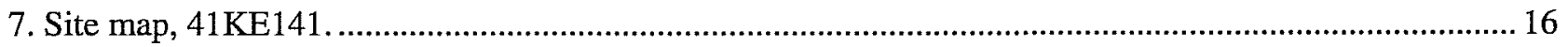

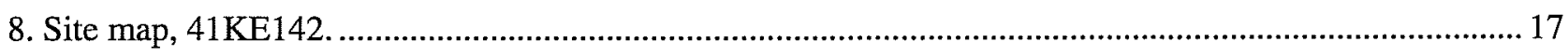

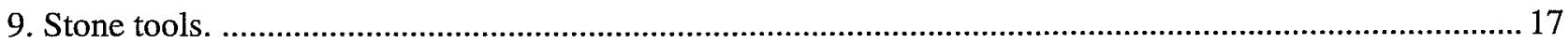

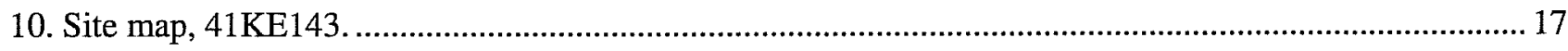

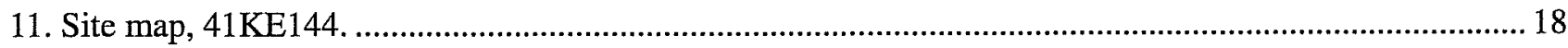

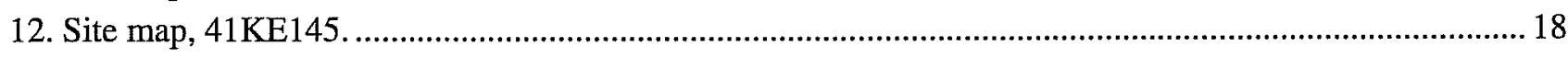

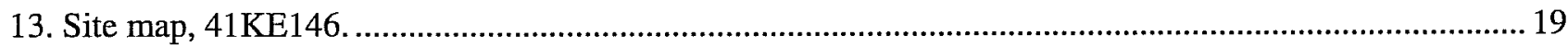

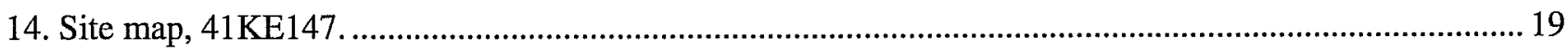

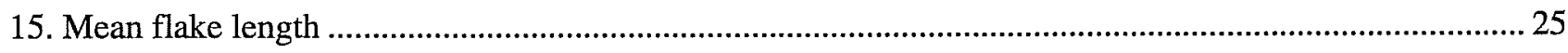

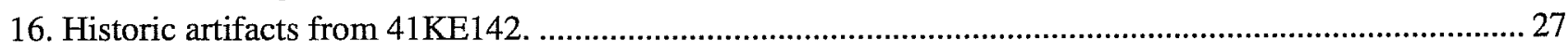




\section{Tables}

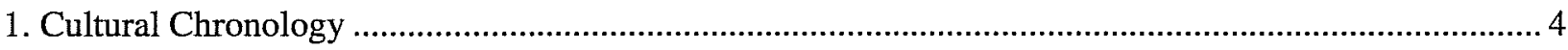

2. Shovel Test Sampling Results. .............................................................................................. 15

3. Standard Deviation Analysis for Debitage Cortex by Site ...............................................................26

4. Standardized Deviation Analysis for Cores, Bifaces, Unifaces, and Points by Site ........................... 28

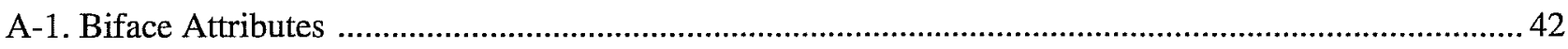

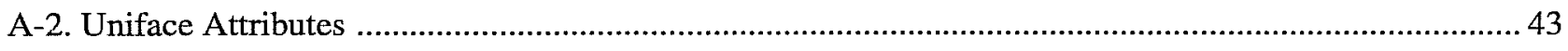

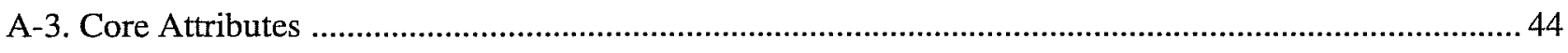

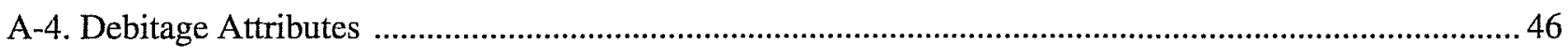

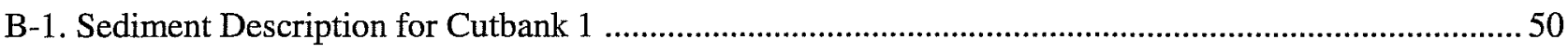

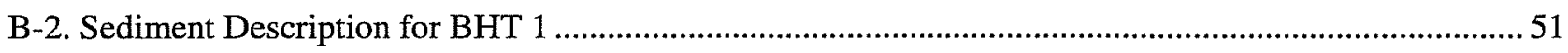

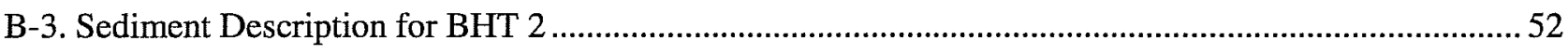

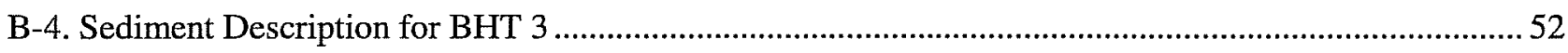

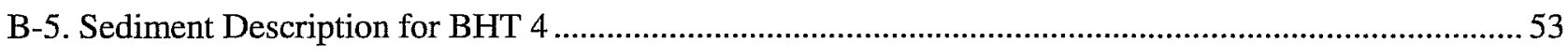

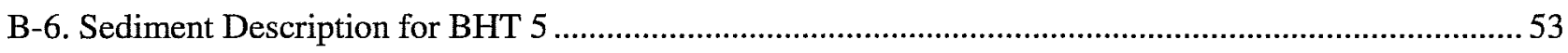

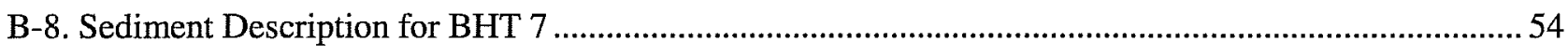

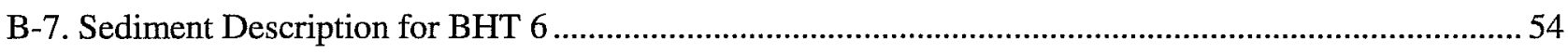

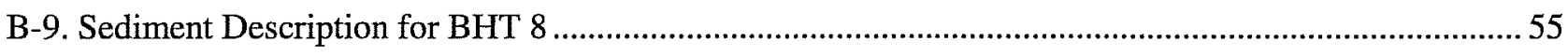

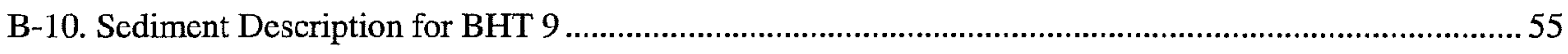

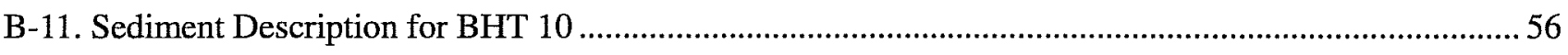

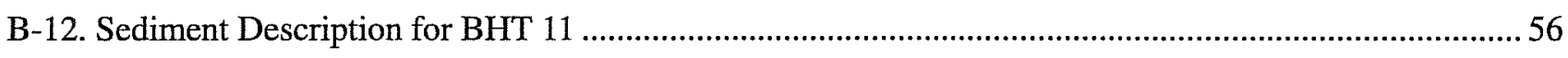

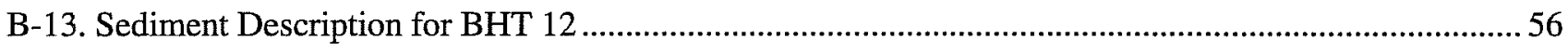

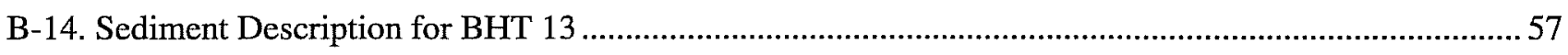




\section{Acknowledgments}

The author would like to thank Mr. Christopher Turk, director of planning and community services for the city of Boerne, for his enthusiastic cooperation, expertise, and assistance throughout the project. Claude Culak and Dave Carlson of the Boerne City Public Works Department lent their full support, and Jose Escajeda skillfully operated the backhoe for our geomorphological study.

The project could not have been completed without the able fieldwork of UTSA staff archaeologists Johanna Hunziker, Edgar Johnson, Bruce Moses, and Andrew Scease; three stalwart volunteers-Jeffrey Francis, Preston McWhorter, and Eve Santos-who were there every day despite the adverse weather conditions; and Gloria Murguia, Erik Kreusch, and Connie Gibson who also helped. Bruce Moses contributed his expertise in artifact illustration for this report, and as always, Marcie Renner's and James Rodriguez's technical support as editors is greatly appreciated. Dr. Thomas R. Hester willingly allowed us to include a piece of obsidian as part of the Texas Obsidian Project. A special thanks to Dr. Steve Tomka, Dr. John Cross, and Wilson McKinney for their advice and support during the lithic analysis. Dr. Robert J. Hard and Dr. C. Britt Bousman are thanked for providing professional advice and guidance throughout the project. 



\section{Introduction}

In March 1996, the city of Boerne, Texas, contracted with The Center for Archaeological Research (CAR) of The University of Texas at San Antonio to conduct an archaeological site assessment via a pedestrian survey and limited shovel and backhoe testing of the 103-acre proposed Northrup Park. The city of Boerne asked for the assessment as part of a grant proposal to the Texas Parks and Wildlife Department. Northrup Park is located adjacent to $\mathrm{IH}-10$ West, immediately north of John's Road in Boerne, south Kendall County
(Figure 1). Planned development of the 103 acres of land as a new city park includes construction of playing fields, bathrooms, parking lots, a basketball pavilion, swimming pool, bath house, picnic areas, and an access road. The survey found and documented seven archaeological sites, four of which would be impacted by construction and one which is adjacent to an improved road.

Robert J. Hard served as principal investigator, and C. Britt Bousman was the co-principal investigator for the project. David L. Nickels acted as project

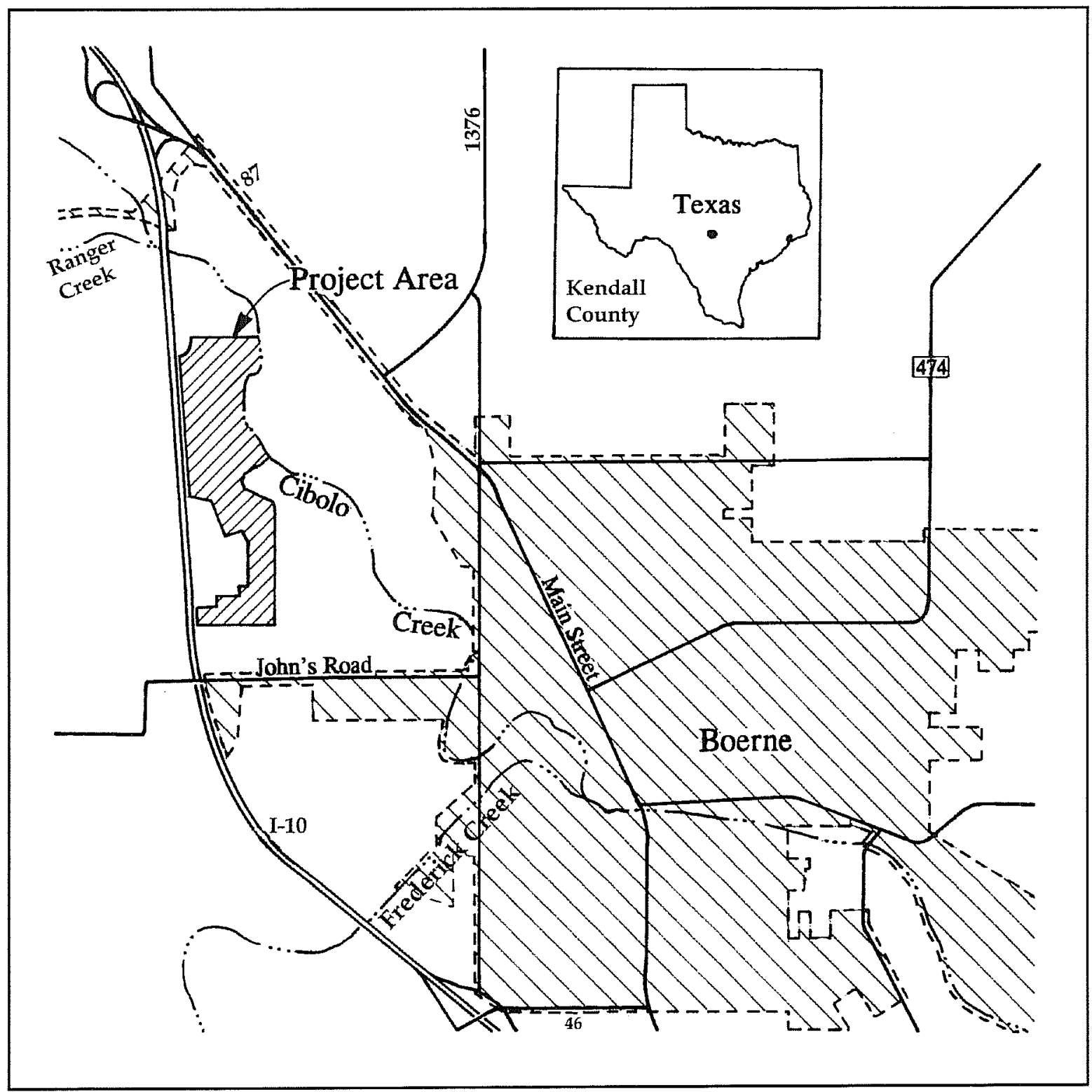

Figure 1. Project area location. 
archaeologist and was responsible for data collection, analysis, and report preparation. C. Britt Bousman conducted the geomorphological study of the project area.

\section{Project Area}

The project area lies in the southern portion of the Edwards Plateau, in central Texas's "Hill Country," so named for its rugged, stream-eroded topography. The Edwards Plateau comprises most of Central Texas, and its southern and eastern boundary is formed by the Balcones Escarpment. Beyond the escarpment is the South Texas Plains, with a distinctive modern shrub brush vegetation.

Three different environmental zones encompass the project area: terrace, creek, and uplands. The northern half of the 103-acre tract is a gently undulating plowed alluvial terrace, previously used for animal grazing and hay cultivation. The field is eroded by an incised Cibolo Creek on the east, forming an eight-meter bluff. South of the field, the surface rises above a four-meter bluff to oak-, juniper-, and grass-covered uplands. Edwards limestone cobbles are frequently exposed on the surface in the uplands. The uplands are eroded on the south where two intermittent drainages dissect lower terraces, exposing bedrock bottoms (Figure 2). The annual average rainfall is about $77 \mathrm{~cm}$, with 194 growing-season days per year (Dittemore and Hensell 1981:64-65). The area supports abundant herds of imported axis and native whitetail deer. Other animals observed during survey were armadillos and numerous species of birds.

Approximately 45 percent of the project area's surface is covered with Oakalla silty clay loam (Figure 2), a soil normally present on floodplains of streams such as Cibolo Creek. Five percent of the project area is covered with Krum silty clay, which commonly occurs at the base of limestone hills. Ten percent is covered with Denton silty clay, a soil that occurs in the uplands over a weakly cemented limestone or marl base (Dittemore and Hensell 1981:14, 20, 23). About 20 percent of the project area's surface is covered with Doss-Brackett association soils. These undulating surfaces are generally shallow, loamy and clayey, and

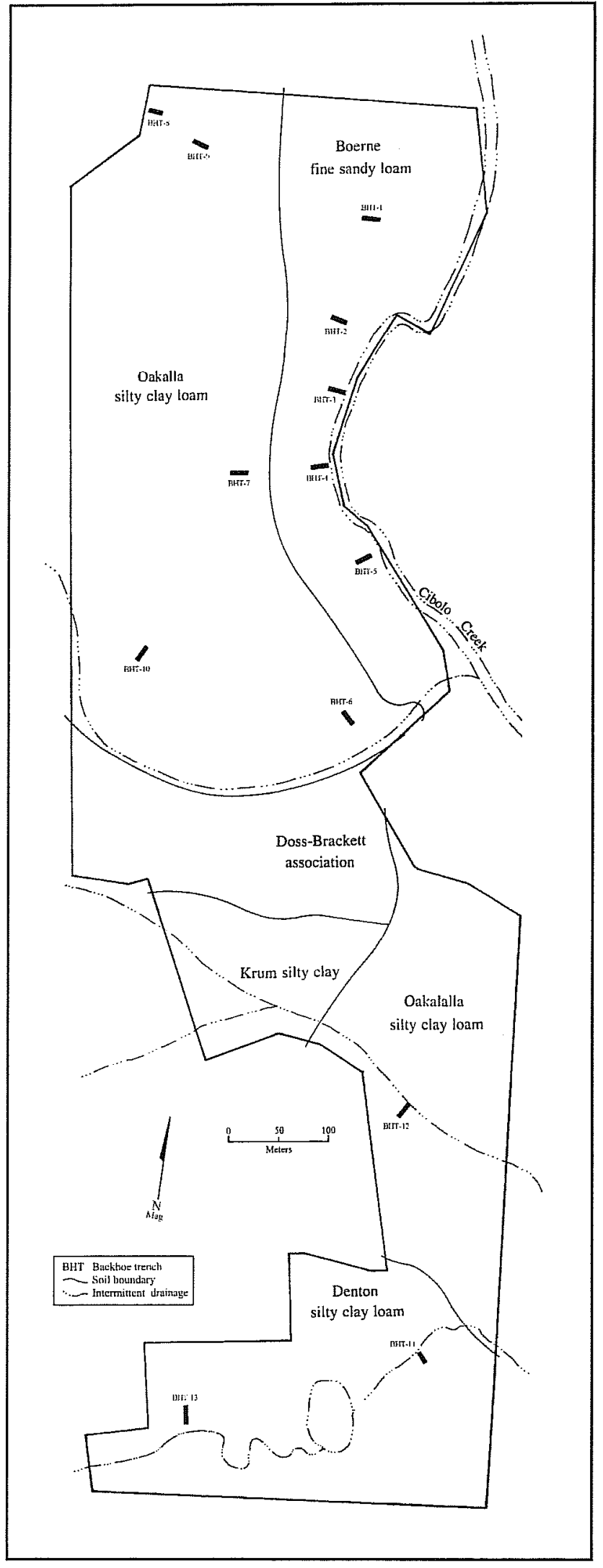

Figure 2. Project area. 
sit on either hard limestone, white, soft chalky sediments, or weakly cemented limestone and marl. Another 20 percent of the area is covered with Boerne fine sandy loam, a deep soil that generally occurs on flood plains or alluvial fans (Dittemore and Hensell 1981:11, 17, Sheets 19, 22).

The riverine environment of Cibolo Creek and the terraces supports more-mesic plants and aquatic animals. The Cibolo drainage begins approximately $16 \mathrm{~km}$ west of Boerne from springs flowing out of Edwards Limestone hills, and flows along the northeastern edge of the project area. A few kilometers downstream the creek disappears from the surface as it drops into the Glen Rose formation (Gerstle et al. 1978:31). The creek is subject to flash flooding during locally heavy thunderstorms. In the creek bottoms, tall trees shade the ground, leaving little light for understory growth. The higher alluvial terrace is covered with small trees and a medium to heavy brush cover in areas where it has not been plowed. Aquatic animals-including fish, turtles and frogs-and mesophytic plants such as cattails would have provided food resources in prehistory. Poor quality lithic resources were observed in the cutbank along Cibolo Creek, however the hilltops to the west apparently provide high quality chert for making stone tools (Gerstle et al. 1978:31).

The predominant vegetation throughout the project area consists of live oak (Quercus virginiana) and Texas cedar (Juniperus ashei) (Simpson 1988:180, 301). The upland area offers level ground, providing room for prehistoric residential camps, quick and easy access to the resources of the creeks and uplands, some shade, and protection from flash floods.

\section{Cultural History}

The importance of the wide variety of landform and vegetation regions in the area, along with the presence of permanent water, cannot be overemphasized in considering the history of the area. This variety of resources, including the plants and animals of differing biotic zones and the lithic resources available within a short distance, made this a rich region from the viewpoint of its prehistoric inhabitants. More importantly, the diversity provided a kind of "insurance" against the vagaries of seasonal and climatic variation. Problems associated with these variations could be ameliorated by simply moving a few miles-and into a different biotic and/or vegetative zone. Availability of water would seldom have been a problem, for throughout the area were numerous rivers, creeks, and springs (Brune 1975).

The high prehistoric population of central Texas has resulted in a rich archaeological heritage. Some researchers estimate that the Native American population in the region just prior to European contact may have been as high as 150,000 (Dobyns 1966). Due to modern population growth, substantial urban development has resulted in the destruction of numerous archaeological sites.

\section{Prehistoric Chronology}

Detailed chronologies like those of Prewitt (1981, 1985) have been seriously criticized as some scholars believe there is not enough evidence in the archaeological record at this time to warrant such interpretation (Black 1989a:24; Johnson 1987:12). In addition, many feel that central Texas is too widely diverse in environments and cultures to allow such a detailed regional chronology (McGraw 1985:319-321; Peter et al. 1982a:21-25 ). Because it is so often referred to in other literature, Prewitt's $(1981,1985)$ scheme is often placed in context with successive schemes (Black 1989a, 1989b; Story 1985). Collins (1995) has synthesized the schemes presented for the region and his interpretations serve as the basis for the analysis of the archaeology found in Northrup Park (Table 1).

While more work on the prehistoric cultural sequence on the Edwards Plateau is still needed, a cultural history applicable to the project area is in place and presented below, covering both the prehistoric and historic eras. While no diagnostic artifacts exclusive to the Paleoindian period were identified, the potential does exist for an early presence in the project area and thus warrants discussion here. 
Table 1. Cultural Chronology

\begin{tabular}{|c|c|c|c|c|}
\hline $\begin{array}{l}\text { Genlogic } \\
\text { Eponh }\end{array}$ & $\begin{array}{l}\text { Archemological } \\
\text { Periouts }\end{array}$ & $\begin{array}{c}\text { Archacological } \\
\text { Style } \\
\text { Iatervals }\end{array}$ & $\begin{array}{c}\text { Oldest } \\
\text { Calcadar } \\
\text { Year }\end{array}$ & $\begin{array}{c}\text { Radio- } \\
\text { Carbon } \\
\text { Ycars B.P. }\end{array}$ \\
\hline \multirow{4}{*}{$\begin{array}{c}\text { Late } \\
\text { Holocene }\end{array}$} & Historic & & A.D. 1690 & $0-260$ \\
\hline & $\begin{array}{c}\text { Late } \\
\text { Prehistoric }\end{array}$ & $\begin{array}{l}\text { Perdiz } \\
\text { Scallom } \\
\text { Ed wards }\end{array}$ & A.D. 950 & $260-1200$ \\
\hline & $\begin{array}{l}\text { Late } \\
\text { Archaic }\end{array}$ & $\begin{array}{c}\text { Darl } \\
\text { Ensor, Frio, } \\
\text { Fairland } \\
\text { Marcos, Montell, } \\
\text { Castroville } \\
\text { Lange, Marshall, } \\
\text { Williams } \\
\text { Pedernales, } \\
\text { Kin ney } \\
\text { Bulverie }\end{array}$ & 2050 B.C. & $4000-1200$ \\
\hline & \multirow{2}{*}{$\begin{array}{l}\text { Middle } \\
\text { Arch aic }\end{array}$} & $\begin{array}{c}\text { Nolan, Travis } \\
\text { Taylor }\end{array}$ & & \\
\hline \multirow{2}{*}{$\begin{array}{c}\text { Middle } \\
\text { Holocene }\end{array}$} & & $\begin{array}{l}\text { Bell-And ice- } \\
\text { Calf Creek }\end{array}$ & 4050 B.C. & \\
\hline & $\begin{array}{l}\text { Early } \\
\text { Archaic }\end{array}$ & $\begin{array}{l}\text { Martindale, } \\
\text { Uvalde } \\
\text { Early Split } \\
\text { Stem } \\
\text { An gostura }\end{array}$ & 6850 B.C. & \\
\hline $\begin{array}{l}\text { Early } \\
\text { Holocene }\end{array}$ & Paleoindian & $\begin{array}{c}\text { St. Mary's Hall } \\
\text { Golondrina- } \\
\text { Barber } \\
\text { Wilson } \\
\text { (Dalton, } \\
\text { San Patrice) } \\
\text { (Plainview) } \\
\text { Folsom } \\
\text { Clovis }\end{array}$ & 9550 B.C. & \\
\hline
\end{tabular}

Collins (1995) reviewed the archaeological and palynological evidence for central Texas and offers new approximate dates for human occupation from the Paleoindian through Historic periods. The following dates and discussion are derived primarily from this most recent work, with a brief discussion of the Transitional Archaic as defined by Turner and Hester (1993). All dates are approximate and given as "before present” (B.P.), i.e., before 1950.

\section{Paleoindian}

This phase spans the period between ca. 11,500-8800 B.P. The Paleoindian period began toward the close of the Pleistocene. Diagnostic artifacts include Clovis and Folsom projectile points. Certainly the wide distribution of Clovis points across most of North
America and even into Central America suggests a wide dispersal of the people who made them (Kelly 1993; Wenke 1990:201). Other artifacts associated with the Clovis culture include bifaces, prismatic cores and blades, engraved stones, bone and ivory points, stone bolas, ochre, and shaft straighteners.

In general, the Paleoindian adaptation has been considered to be one of small bands of nomadic, big-game hunters following herds of Late Pleistocene fauna, including mammoth, mastodons, bison, camel, and horse across North America (Black 1989a). More recently, emphasis has been on the wide diversity of plants and animals used for subsistence by these early Americans (Black 1989a; Hester 1983), such as turtles and tortoises, alligators, mice, badgers, and raccoons (Collins 1995:381), although they undoubtedly hunted the large animals as well (Dibble and Lorraine 1968). Known Clovis site types include killsites, quarries, caches, open campsites, ritual sites, and burials (Collins 1995:381-383; Hester 1995:433-436).

Most Paleoindian finds in central and south Texas have consisted of surface lithic scatters on upland terraces and ridges (Black 1989a:25, 1989b:48). A few Paleoindian sites deeply buried in alluvium have been discovered at the Berger Bluff site (Brown 1987), the Kincaid Rockshelter (Collins et al. 1989), and at recent excavations of the Wilson-Leonard site (Collins et al. 1993). Many Paleoindian points have been recovered from surface contexts in Bexar and nearby counties (Chandler and Hindes 1993; Hester 1968a, 1968b; Howard 1974; Meltzer and Bever 1995: 47-81; Nickels et al. 1997; Prewitt 1995:83-173).

As the warming that marks the transition from Pleistocene to Holocene climates began to take effect in Texas, prehistoric inhabitants adapted with changes in lifestyle. This climatic shift is also marked by the decline and extinction of mammoth, mastodon, camel, and giant bison (Bison antiquus). After 8000 B.P., no large gregarious game animals remained in Texas; even the smaller modern bison (Bison bison) was gone temporarily (Dillehay 1974). Human hunters were forced to concentrate on deer, antelope, and other mediumsize or smaller game. Changes in the subsistence base required technological shifts that mark the beginning of a new cultural period known as the Archaic. 


\section{Early Archaic}

Collins argues that the Early Archaic spans the period from 8800-6000 B.P. in central Texas, with three divisions based on projectile point types (Collins 1995:383). The extinction of large herds of megafauna and the changing climate at the beginning of the Holocene stimulated a behavioral change by the prehistoric inhabitants of South Texas (McKinney 1981). While the basic hunter-gatherer adaptation probably remained intact, an economic shift away from big game hunting was necessary. In general, more intensive exploitation of local resources in central Texas-such as deer, fish, and plant bulbs-is indicated by more ground-stone artifacts, fire-cracked rock cooking features, and more specialized tools such as Clear Fork and Guadalupe bifaces (Turner and Hester 1993:246, 256). Weir (1976) speculates that Early Archaic groups were small and highly mobile, an inference from the fact that Early Archaic sites have a low settlement pattern density and that diagnostic artifact types are seen across a wide area, including most of Texas and northern Mexico. Story (1985) believes that population densities were low during this period, and that groups were comprised of related individuals in small bands with "few constraints on their mobility" (Story 1985:39). Their economy was based on utilization of a wide range of resources, especially such year-round resources as prickly pear and lechugilla, as well as rodents, rabbits, and deer (Story 1985:38). Sites near the study area with Early Archaic components are found at Camp Bullis, in northern Bexar County (Gerstle et al. 1978).

\section{Middle Archaic}

Collins (1995:383) defines this intermediate interval of the Archaic as lasting from about 6000-4000 B.P. in central Texas. The Middle Archaic appears to have been a time of increased population, based on the large number of sites from this period in south and central Texas (Story 1985:40; Weir 1976:125, 128). The reasons for this increase are not known, but the amelioration of a very dry period (Altithermal) during the Early Archaic is often seen as the prime mover (Sollberger and Hester 1972:338; Story 1985:40). On the South Texas Plains, exploitation of widely scattered, year-round resources such as prickly pear continued (Campbell and Campbell 1981:13-15), as did hunting deer and rabbit. However, a shift to the use of concentrated, seasonal nut harvests in the riverine environments of the Balcones Escarpment seems to have occurred (Black 1989a). Weir (1976) believes that an expansion of oak on the Edwards Plateau and Balcones Escarpment led to intensive plant gathering and acorn processing. He also believes that the widely scattered bands prevalent in the Early Archaic now began to coalesce, at least during the acorn-gathering season, into larger groups who shared the intensive work of gathering and processing the acorn harvest (Weir 1976:126). Many researchers believe burned rock middens are a result of this endeavor (Creel 1986; Prewitt 1991; Weir 1976). Other investigators doubt burned rock middens are the results of acorn processing (Black et al. 1993; Goode 1991; Rector 1993), but the exact processes which formed these features are still a matter of controversy (Black 1989a:28; Black et al. 1997; Nickels and Bousman 1998).

The common presence of deer remains in burned rock middens encourages the view that deer processing was very much a part of the work at burned rock midden sites (Black and McGraw 1985:278; Weir 1976:125). Bison bone is encountered in archaeological sites in central and south Texas, at least occasionally, during all but the earliest part of the Middle Archaic (Dillehay 1974). There has been a tendency to equate presence of burned rock middens with absence of bison (Prewitt 1981); however, examinations of several recent faunal reports show that after about 4500 B.P. bison and burned rock middens are contemporaneous, though not at the same sites, at least in the southern Edwards Plateau and northern South Texas Plain (Meissner 1993).

\section{Late and Transitional Archaic}

Collins (1995:384) dates the final phase of the Archaic to approximately $4000-1200$ B.P. Some researchers believe populations increased all throughout the Late Archaic (Prewitt 1985), while others feel populations remained the same or fell during this period (Black 1989a:30). Prewitt (1981:80-81) asserts that the construction of burned rock middens nearly ceased during the course of this period. Subsistence is 
assumed to have become less specialized and focused on acorns, in favor of a broad spectrum subsistence base (Black 1989a:30). By about 1450 B.P., bison had again disappeared (Dillehay 1974).

A proliferation of distinguishable human cemeteries has been attributed to this period, with the earliest occurrences dating to the south Texas Middle Archaic (Hester 1995:439-440). At Loma Sandia, these date between ca. 2550 and 2750 B.P. (Taylor and Highley 1995). Story (1985:44-45) believes the presence of cemeteries at sites such as Ernest Witte (Hall 1981); Hitzfelder Cave, 41BX26 (Givens 1968); and 41BX1 (Lukowski 1988) indicates that Late Archaic populations in central and south Texas were increasing and becoming more territorial.

Although inhabitants of the South Texas Plain near Brownsville and Rockport had begun to make pottery by about 1750 B.P., the northern part of the plain was still "pre-ceramic" until 1,000 years later (Story 1985:45-47). Late Archaic points tend to be much smaller than Middle Archaic points. The most common are Ensor and Frio types (Turner and Hester 1993:114,122), both of which are short, triangular points with side notches. The Frio point also has a notched base (Turner and Hester 1993:122).

A late subperiod or interval of the Late Archaic is frequently referred to as the Terminal Archaic or Transitional Archaic. Weir (1976) dates the Terminal Archaic to $1650-1150$ B.P., while Turner and Hester (1993) place the Transitional Archaic at 2250-1250 B.P. Weir (1976) believes this marked a transition period to localized area sites, a disappearance of burned rock middens and bison, and a reappearance of highly mobile hunters and gatherers. Others (Black and McGraw 1985; Peter et al. 1982b; Skelton 1977) argue that in some locations burned rock middens did not disappear and sites were more intensely occupied during the Terminal Archaic period.

\section{Late Prehistoric}

Collins (1995:385) recognizes that the commonly used date of 1200 B.P. for the end of the Archaic in central Texas is arbitrary. A series of distinctive traits marks the shift from the Archaic to the Late Prehistoric period, including the introduction of the bow and arrow and the introduction of pottery to central Texas and the northern South Texas Plain (Black 1989a:32; Story 1985:45-47). Most researchers agree the early Late Prehistoric period was a time of population decrease (Black 1989a:32). Even though small burned rock middens associated with Scallorn and Edwards points have been found (Goode 1991:71), they are rare. Settlement shifts into rockshelters have been noted (Shafer 1977; Skinner 1981). Cemeteries from this period often reveal evidence of conflict (Black 1989a:32). For example, one burial at the Cottonwood Terrace site had a Scallorn point embedded in the cervical spine (Benfer and Benfer 1965), and an excavation of a burial just north of San Antonio (41BX952) revealed an Edwards point between two lumbar vertebra (Meissner 1991). Sites from the Austin phase include 41BX274 (McGraw and Hindes 1987); Quinta Medina (Guderjan et al. 1992, 1993); and Panther Springs Creek, 41BX228 (Black and McGraw 1985).

Beginning rather abruptly at about 650 B.P., a shift in technology occurred. This phase is characterized by the introduction of blade technology, the first ceramics in central Texas (bone-tempered plainwares), the change to Perdiz arrow points, and alternately beveled bifaces (Black 1989a:32; Huebner 1991:346). Prewitt (1985) and Black (1989a) both believe this phase came out of north-central Texas. Patterson (1988), however, notes the Perdiz point was first seen in southeast Texas by about 1350 B.P., and was introduced to the west some 600-700 years later. Hester (1995:444) recognizes this phase as the "best documented Late Prehistoric pattern" throughout south Texas, with dates ranging between ca. $650 / 700-300 / 350$ B.P. (A.D. $1250 /$ 1300-1600/1650).

Steele and Assad Hunter (1986) argue for the occurrence of a distinct change in diet between the Late Archaic and the Late Prehistoric components in two sites in Choke Canyon Reservoir in south Texas. Analysis of the number of identified specimens (NISP) shows a marked increase in artiodactyl elements present during the late Late Prehistoric, an increase largely due to the addition of bison to the "menu" (Steele and Assad-Hunter 1986:468). Huebner (1991) suggests that the sudden return of bison to south and central Texas resulted from a more xeric climate in 
the plains north of Texas, and increased grassiness in the Cross-Timbers and Post Oak Savannah in north central Texas, forming a "bison corridor" into the South Texas Plain along the eastern edge of the Edwards Plateau (Huebner 1991:354-355). Sites from this period frequently have associated bison (Black 1986; Black and McGraw 1985; Henderson 1978; Hulbert 1985; Prewitt 1974).

The only archaeological evidence that domesticated plants were ever introduced in south or central Texas is a single corncob found in Late Prehistoric context in Timmeron Rock Shelter (Harris 1985). This single cob is not enough to postulate there was ever a significant presence of maize in the area. Only the arrival of the Spanish brought significant cultivars to south and central Texas.

\section{Historic Period}

The end of the Late Prehistoric and beginning of the Historic period in both central and south Texas can be characterized by written accounts of European contact with indigenous groups. Collins (1995:386-387) offers that the Historic period then begins ca. 260 B.P. in central Texas. However in south Texas, Hester (1995:450-451) agrees with Adkins and Adkins (1982:242) when he suggests that the indigenous groups may have been affected by European influence, but adds that we are only able to observe the materials in the archaeological record because the written accounts simply are not available. He would rather label this largely unknown period "Protohistoric."

The cultural context for the historic groups in the study area is largely conditioned by the presence of outside ethnic groups and regional power struggles. The numerous small groups of Coahuiltecans encountered by the early explorers and later Spanish intrusions are addressed in many sources (Campbell 1983; Campbell and Campbell 1985; Hester 1989; John 1975; Newcomb 1961; Swanton 1952). The various later intrusive groups, such as Tonkawa, Lipan Apache, and Comanche, are also described by numerous researchers (Ewers 1969; Hester 1989; Jones 1979; Kelley 1971; Newcomb 1961, 1993; Sjoberg 1953a, 1953b).
At the beginning of the seventeenth century, many south Texas Indian groups were being pushed northward by continual Spanish expansion. By the mid-seventeenth century, a new pressure on the Indians indigenous to the area began to be applied from the northern nomadic group, the Apache. The Apache were adapted to a Plains-lifeway style of bison hunting, especially once they acquired horses from the Spaniards (Campbell and Campbell 1985:27). Later, the Apaches were displaced by another group of nomadic, bison-hunting Indians-the Comanchesfrom the High Plains of Texas (Campbell 1991:111).

Warfare with intrusive Native American groups, migration, demoralization, inner-group conflict, disease, and death fragmented the indigenous Indian groups, and forced continual mixing and remixing among them (Bolton 1970[1915]; Campbell 1975, 1991:345; León et al. 1961). Most of the native languages have been lost, although recent attempts at reconstruction are enlightening (e.g. Johnson 1994; Johnson and Campbell 1992). The establishment and relocation of Spanish Catholic missions along the San Antonio River in the late 1600 s and early 1700 s induced many groups to seek the relative comfort, protection, and seemingly peaceful coexistence offered by the Spanish missionaries (Campbell and Campbell 1985; Chipman 1992; de la Teja 1995; Habig 1968a, 1968b; Hard et al. 1995; Inglis 1964). Although fear of the invading Apache and Comanche pressured many of the Indians to seek the protection of missions, they were now exposed to the exploitation of the Spanish (Campbell 1975:2, 1991:346-347).

Few landowners dared to live on their outlying lands until about 1749 , when a treaty with the Apaches brought peace for a while (de la Teja 1995:100). The Apache, pushed southward by the invading Comanche who had moved into the hill country of central Texas, continued to range over the area between San Antonio and Laredo until the early 1800s (Campbell and Campbell 1985:27). Weary of warfare with the Comanche, a few Apache began to seek asylum in the missions (McGraw and Hindes 1987:367; West 1904:50).

In the autumn of 1785 , a peace treaty was agreed to in Santa $\mathrm{Fe}$ between Don Juan Bautista de Anza 
representing the Spanish Crown and Cuera (Leather Jacket) representing the Comanches. The treaty signaled the opening of a period of peaceful coexistence in what is today Bexar County, in which Comanches brought hides, meat, and tallow to San Antonio to trade for goods and services not available elsewhere, such as blacksmithing and gun repair (Fehrenbach 1978:221-224; Poyo and Hinojosa 1991:125-126). The few Comanches who entered the missions were apparently women and children who were captured during punitive raids by Spanish soldiers (Campbell and Campbell 1985:26).

The newly formed government of Texas gave land grants that were large, consisting of around 5,000 acres for each property, and Spanish cattle ranching became prevalent south and southeast of San Antonio (Jackson 1986). However the political turmoil that permeated early Texas caused the near-complete European desertion of San Antonio following the Mexican War for Independence (Fehrenbach 1983).

Around 1840 settlers from Germany and AlsaceLorraine and from other regions of the United States began to flood into San Antonio. Many of the Germans moved into the Hill Country to the north, settling into communities, and raised sheep or cattle (Freeman 1994:5-9). As the sheep and cattle markets emerged in the 1880s ranchers and farmers settled farther away from San Antonio (Flanagan 1974; Lehmann 1969; Nickels et al. 1997). The introduction of twentiethcentury technologies such as mills and improved methods of production have shaped the area as it exists today (Fox et al. 1989).

\section{Previous Archaeology}

Although professional archaeologists have been investigating Texas for over 60 years, some areas have received more attention than others. Sites along Cibolo Creek and its tributaries are both diverse and common. Site types include open campsites, burned rock middens, small lithic scatters, large lithic workshops, caves, and rockshelters.

Large-scale surveys covering thousands of acres along the Balcones Escarpment and the eastern Edwards
Plateau have been highly effective in discovering archaeological sites. Seventy-two sites were recorded on 5,600 acres at Camp Bullis in northern Bexar County (Gerstle et al. 1978). The survey covered the watersheds of Upper Cibolo, Ranger, and Upper Salado creeks. Thirty-four of those sites were associated with diagnostic lithic tools from the Paleoindian through Late Prehistoric periods. Thirtyfour sites containing Paleoindian through Late Archaic components were recorded during a 2,500-acre survey of the East and West Elm Creek branches of Upper Salado Creek in the Encino Park area of northern Bexar County (McGraw et al. 1977:10-29).

Thirty-nine sites dating from the Paleoindian through Late Prehistoric periods were found during a 887-acre survey of the Upper Cibolo Creek watershed on Upper Cibolo, Ranger, Frederick, and Deep Hollow creeks, approximately $12 \mathrm{~km}$ west of the project area, in southern Kendall County (Bass and Hester 1975; Kelly and Hester 1976a). Paul McGuff recorded 28 prehistoric sites along Leon Creek in northern Bexar County in 1970 and 1971 (site reports on file at CAR).

CAR archaeologists recorded two prehistoric sites in Boerne City Park on the southeast side of the city (Kelly and Hester 1976b). Avocational archaeologists recorded nine sites on the Upper Cibolo on the Weaver Adams Ranch in western Kendall County (Patterson and Adams 1977:6). Most of the sites recorded in Kendall County were found during surveys conducted in the 1970s, little work has been done in the area since. As of April 1996, Kendall County had 147 documented archaeological sites.

\section{Prehistoric Site Density}

Some indications of expected site density are available. The large-scale surveys along the Cibolo and Salado creeks watersheds (see above) documented 145 sites over 8,987 acres, or one site per 62 acres. However the data seem skewed by the Encino Park and Camp Bullis surveys, which yielded one site per 78 and 74 acres respectively, significantly less dense than survey results conducted in the upper reaches of the Cibolo just above the project area, which yielded one site per 23 acres (Bass and Hester 1975; Kelly and Hester 
1976a). Collins (1995) suggests that sites in the upper reaches of small streams are more visible on the surface because there has been less deposition occurring at higher levels. Thus the project area was expected to yield less sites per acre than the Upper Cibolo survey and more per acre than the Encino Park and Camp Bullis surveys.

Another consideration in predicting site density is proximity to water. Surveys along the Salado Creek watershed (Boyd et al. 1990; Gerstle et al. 1978; Quigg 1988) support the inference that site density along the first and second terraces of creeks is fairly high. For instance, along approximately eight kilometers of Upper Salado Creek on Camp Bullis Military Reservation, Quigg (1988:Figure 2) shows 10 sites on the first or second terrace, or about 1.25 sites per kilometer of water course. Cibolo Creek flows for .6 $\mathrm{km}$ along the east edge of a 53-acre plowed terrace on the project area and intermittent drainage terraces are present in the southern end, increasing the potential for sites. After considering all the data from previous surveys and proximity to water, and after examining the terrain features using topographic maps and aerial photos, we expected to find six sites within the 103acre project area.

\section{Site Types}

Five types of prehistoric sites are found in central Texas: 1) open camp sites, with either single or multiple temporary occupations; 2) burned rock midden sites, with or without associated camp sites; 3) rock shelters; 4) chert quarry sites; and 5) burial sites. The presence of historic sites is also expected.

Open campsites are defined by the presence of firecracked rock (occurring in varying quantities), finished tools, and thinning flakes or other advanced reduction stage debitage. These sites consist of thin lithic scatters representing a single occupation (Boyd et al. 1990), or deeply stratified, multicomponent sites to which groups repeatedly returned for thousands of years (Black and McGraw 1985; Guderjan et al. 1992).

Burned rock middens are common over central and west Texas. These consist of piles of heat-fractured limestone, usually in a conical pile but occasionally in rings or U-shapes. The piles can measure tens of meters in diameter with a meter or more depth. Although the exact nature of the activities at these sites is still a matter of debate (Black et al. 1993; Black et al. 1997; Creel 1986; Hester 1970; McGraw and Valdez 1978; Nickels and Bousman 1998; Prewitt 1991; Witkind 1977), they are probably the result of intensive use of some resource in a logistically oriented subsistence strategy (Binford 1980). Burned rock middens are usually near water sources (Creel 1986).

Rockshelters are found in solution cavities along creeks where water has cut into limestone bedrock. Repeated use of these shelters by prehistoric and historic populations is documented throughout Texas. Rockshelters are common along creeks cutting through the Balcones Escarpment (Boyd et al. 1990; Guderjan 1991).

Chert quarry sites can occur at outcroppings of limestone containing numerous chert nodules, while other areas have large numbers of chert nodules that have been washed into stream beds. Within the project area, extensive chert gravels are visible in a cutbank along Cibolo Creek. Lithic quarries are present in exposed gravel sheets of varying sizes, and contain related artifacts such as tested cobbles, cores, exterior and interior flakes, and, rarely, finished tools. When fire-cracked rock is present on quarry/workshops, the site is considered a camp and procurement location. Quarry sites usually have a high quantity of primary and secondary flakes, cores, tested cobbles, and large numbers of roughed-out bifaces or quarry blanks, many broken during manufacture (Potter et al. 1992).

Burials may be found in Kendall County, although they are not common. Usually single burials occur at occupation sites. Prehistoric cemeteries first emerge in the Late Archaic, becoming more common in the Late Prehistoric (Prewitt 1981). Associated grave goods are rare. Occasionally, especially in Austin phase (early Late Prehistoric [Collins 1995]) cemeteries, apparent arrow-wound fatalities provide evidence of conflicts (Prewitt 1974). 


\section{Project Goals and Design}

The project goals focused on archaeological issues that could be addressed by the types of data obtained through pedestrian survey, along with limited shovel and backhoe testing. The topics addressed were site type, distribution, density, size, depth, and stratigraphy. The theoretical framework is structured around patterns of settlement, mobility, subsistence, and social systems for the central Texas region. The project also allowed for analyzing the effectiveness of judgemental shovel test sampling in high probability areas versus systematic shovel test sampling in areas of planned impact across the project area.

The goals of the project were to:

1) locate and record cultural locations and sites in the project area using a systematic survey methodology;

2) measure, quantify, and analyze site type, site distribution, site density, and site size, as well as depth, and stratigraphy;

3) measure and quantify the lithic collection and place the diagnostic artifacts within the regional time frame; and

4) implement a sampling strategy designed to evaluate the effectiveness of judgemental versus systematic shovel testing.

\section{Methodology}

\section{Prefield Preparation}

Before beginning the field survey, CAR staff archaeologists inspected the project area to better understand the topography, surface visibility, and site potential. A thorough review of the literature pertaining to the area was conducted. Site and survey reports from the area were examined, as were USGS $7.5^{\circ}$ quadrangle maps, a Kendall County soils survey book, and a geological atlas sheet.

\section{The Survey}

The north half of the project area (53 acres) was a pasture and had been plowed many times in the recent past. We decided to replow the field to the same depth as the old plow zone $(15 \mathrm{~cm})$, providing $100-$ percent surface visibility. Uplands and intermittent creek associated terraces made up the south half of the project (about 50 acres) area (Figure 3). This area had never been plowed and supported varying densities of brush and tree growth. Plowing would not be effective in these areas, so surface inspection and shovel testing were used.

The pedestrian survey began in the northwest corner of the plowed field. Surveyors were organized in twoperson teams. Each team consisted of an experienced surveyor and a student from UTSA. The teams were spaced 30-m apart and walked transects on a specified compass bearing. The ends of each transect were marked with orange flagging tape, showing the compass bearing, date, transect letter (A-VV), and the initials of the team members on that particular transect. Each team worked in a leapfrog manner, using the pace-and-compass method: using a hand-held compass, the first team member would guide the second member forward to a station $30 \mathrm{~m}$ distant. Each station was flagged with toilet paper. Team members meandered between stations to insure better surface coverage. When an artifact was found, orange flagging tape was placed under the artifact, as well as in a tree or bush above it. Crew members used pinflags on the plowed field where no trees or bushes were available. Distance between crews was such that there was constant communication regarding discovered artifacts, and the crew chief was able to examine all finds. If the artifacts present were not sufficient in number to constitute a site by definition, they were recorded on a special form as isolated finds. The only prehistoric materials collected were projectile points and formal tools.

When the artifacts or features present constituted a site by definition, abundant flagging tape was hung in the trees to facilitate returning to the site for further documentation. Upon completion of the pedestrian survey and shovel tests, sites were revisited. Each site was intensely examined to flag newly discovered artifacts and to determine the extent of cultural material 


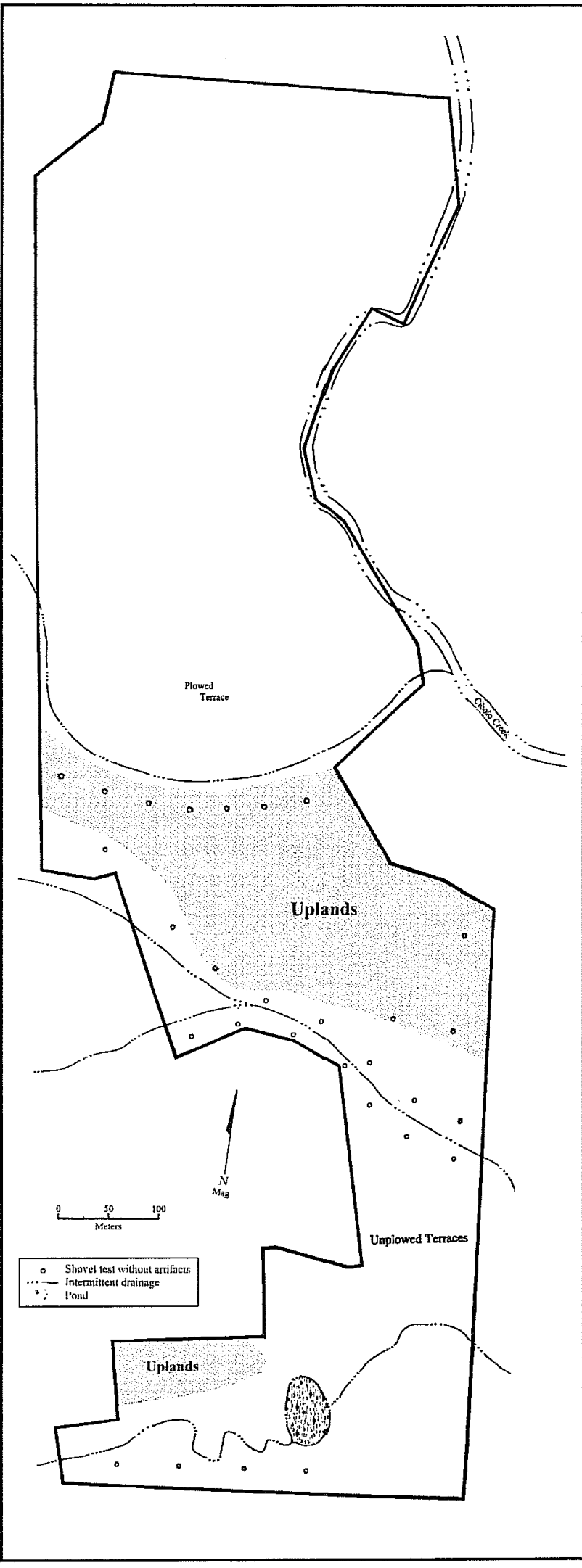

Figure 3. Shovel tests along unplowed terraces and bluff. present on the surface. At least one shovel test was placed on each site to determine approximate depth of the site. A length of rebar was driven into the ground as a site datum. Universal Transverse Mercator (UTM) coordinates were obtained at the datum using a handheld Trimble Navigation Global Positioning System. An aluminum tag was attached to each datum bearing the state trinomial assigned by the Texas Archaeological Research Laboratory, UTM coordinates, date, and "CAR-UTSA." Finally the site was mapped and a 100-percent inventory of surface artifacts was conducted using a standardized form designed for the project. The survey resulted in the location of six prehistoric sites: 41KE141-147.

\section{Surface Collection}

Although the city was extremely concerned about protecting the archaeological sites, it became evident that construction plans could not be altered to avoid impacting sites 41KE141, 41KE142, 41KE143, $41 \mathrm{KE} 144$, and $41 \mathrm{KE} 145$. Site $41 \mathrm{KE} 147$ was adjacent to a road which would be heavily traveled. With the concurrence of the Texas Historical Commission, CAR returned to the project area and conducted a 100percent surface collection of all six sites.

One goal of the surface collection was to gain information regarding intra- and intersite spatial patterning. Ideally a five-square meter grid system (or smaller) would have been superimposed over each site, and each square would have been collected individually. However, an initial assessment of the small quantities of artifacts visible at each site suggested that the information to be gained from such light scatters would be limited. Sites $41 \mathrm{KE} 143,41 \mathrm{KE} 144$, and 41KE145 were generally larger, with a greater number of artifacts; therefore, we decided to divide them into quadrants for collection. Surface artifacts at $41 \mathrm{KE} 141$, $41 \mathrm{KE} 142$, and $41 \mathrm{KE} 147$ were fewer in number and were collected without regard to quadrant. Moderately dense concentrations of artifacts were observed on all but $41 \mathrm{KE} 147$, and a separate 5-x-5-m grid encompassing those concentrations was collected and bagged separately. Unfortunately the information was not as useful as expected because surface visibility was 
impeded by dense weeds and grasses, and thus the collected artifact assemblages are biased with regard to size; smaller tools and debitage were undoubtedly hidden from view (see Artifact Analysis section).

\section{Geomorphological Study}

The project geomorphologist, Britt Bousman, and the project archaeologist, David Nickels, visited the project area to determine the best placement for backhoe trenches. The city of Boerne provided a backhoe with a 28 -inch bucket for two days of testing. Thirteen trenches were strategically placed in areas with the potential for buried cultural material and in areas that would best reveal the changes in subsurface soils and sediments (Figure 2). Trenching operations were monitored by the project geomorphologist and archaeologist. All trenches were then photographed, profiled, and backfilled. The geomorphological study is discussed in Appendix A.

\section{Raw Material Collection}

Initially, the southwestern one square meter of each 5- $\mathrm{x}-5-\mathrm{m}$ collection unit was also delineated, and unmodified raw materials greater than $2.5 \mathrm{~cm}$ in length were collected for analysis. As the collection effort progressed, it became evident that this method would not provide a large enough sample with which to properly evaluate the raw material being used to make artifacts at the sites. Therefore a grab sample was collected from across the entire surface of each site. After the survey, grab samples were collected from the surrounding area, i.e., in a cutbank at the confluence of Cibolo and Ranger creeks, in a downstream cutbank of Cibolo Creek, and in a gravel pit adjacent to the northern edge of the project area. Each raw material sample was counted and weighed in the field, given a bag number, and collected for further examination in the laboratory.

\section{Shovel Testing}

The issue of what is the most effective sampling strategy for finding sites and then determining the potential for buried cultural material is of increasing importance in view of the escalating loss of sites and the increasing cost of conducting archaeological research. Another important consideration is biased site discovery because examination of the surface is inhibited by dense brush and grass cover. The question of how much time, effort, and money should be invested in shovel tests to get the most cost-effective and efficient site discovery method requires careful analysis. It is fairly obvious that while a pedestrian survey with few if any shovel tests may be effective in identifying a surface site in an open field with very little grass or brush, the same would not apply in a highly vegetated area where the surface visibility is extremely low. Critical to any implementation of shovel tests is a choice of sample intervals. Texas terrain is extremely diverse and changes significantly from area to area. While some studies discuss shovel testing, they primarily address site testing and secondarily site discovery (Krakker et al. 1983; Lynch 1980; McManamon 1984; Wobst 1983). Tennis and Hard (1995:19-24) conducted an evaluation of effective shovel-test intervals on 147 acres along Leon Creek in northern Bexar County. Their study suggests that although increasing the interval from 20 to $40 \mathrm{~m}$ has little effect on determining site boundaries and horizontal artifact distributions, it significantly skews the data recovered on site contexts and contents (Tennis and Hard 1995:21).

The Boerne (Northrup) Park project terrain is typical of much of south and central Texas, thus the shoveltest sampling study expands the database of effective sampling procedures. Three hundred-six shovel tests were dug within the 50-acre southern half of the project area. Thirty-five were placed to test sites, 29 were placed within the proposed impact areas, 29 were placed in areas that appeared to have the highest potential for buried sites, and 213 were dug at systematic 30-m intervals along transects (Figure 4). All shovel tests were dug in arbitrary $10-\mathrm{cm}$ levels to 50 $\mathrm{cm}$ or until cemented limestone or bedrock was reached. Sediments and soils were screened through 1/4-inch wire mesh, and documented using standardized recording forms and Munsell soil color charts. Cultural material recovered from shovel tests was collected for analysis. 


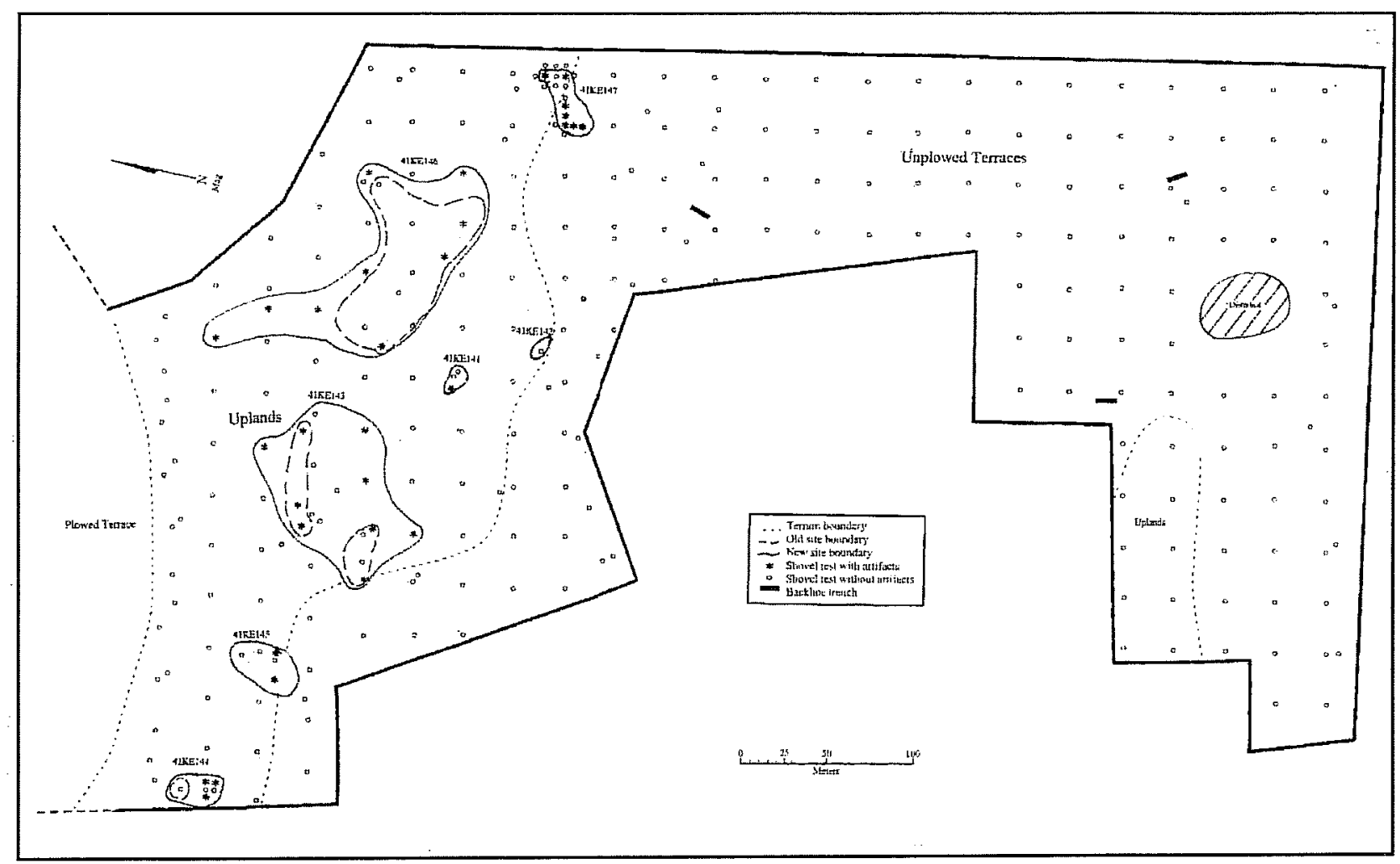

Figure 4. Sites, shovel tests, and backhoe trenches in the south 50 acres of the project area.

Two shovel-test sampling strategies were used over the 50 acres in the uplands and intermittent stream valleys. The first strategy was one traditional to Texas archaeology: to shovel test in areas to be impacted by construction and other areas believed to have high site potential. First, a blueprint of the planned construction was obtained, the areas to be impacted identified, and 13 shovel tests were arbitrarily placed in those areas (Figure 5). Later CAR returned to $41 \mathrm{KE} 143$ and placed 16 more tests along the southern edge which was to be impacted by the construction of a new road. An additional 29 shovel tests were excavated in terraces and ridges along drainages with the greatest potential for sites (Figure 4).

The second strategy involved systematically excavating shovel tests across the south half of the project area in 30-m intervals (Figure 6). This controlled experiment was approached as if the 50 acres had never been surveyed. All previous transect markers, backhoe trenches, shovel tests, and sites were ignored. The time spent excavating and collecting shovel test information was recorded to compare time/costs between the different methods. Driving time was not included as field time, so the hours recorded were actual time spent on site-unloading and loading equipment, marking transects and shovel test stations, digging, screening, collecting sediment data, completing forms, and recovering artifacts.

\section{Laboratory Methods}

All artifacts were washed and air dried. They were then cataloged on worksheets and entered into an Excel spreadsheet. Spreadsheets were designed to total the artifact types and to calculate relative percentages. Research was conducted to formulate a temporal framework for the artifacts, and to identify unique composition and styles. Analytical methods for each artifact type are presented in the Artifact Analysis section.

After analysis, artifacts were put in archival-quality bags with acid-free labels. Each bag was labeled with a provenience or corresponding lot number. Artifact bags were separated by class and stored in acid-free 


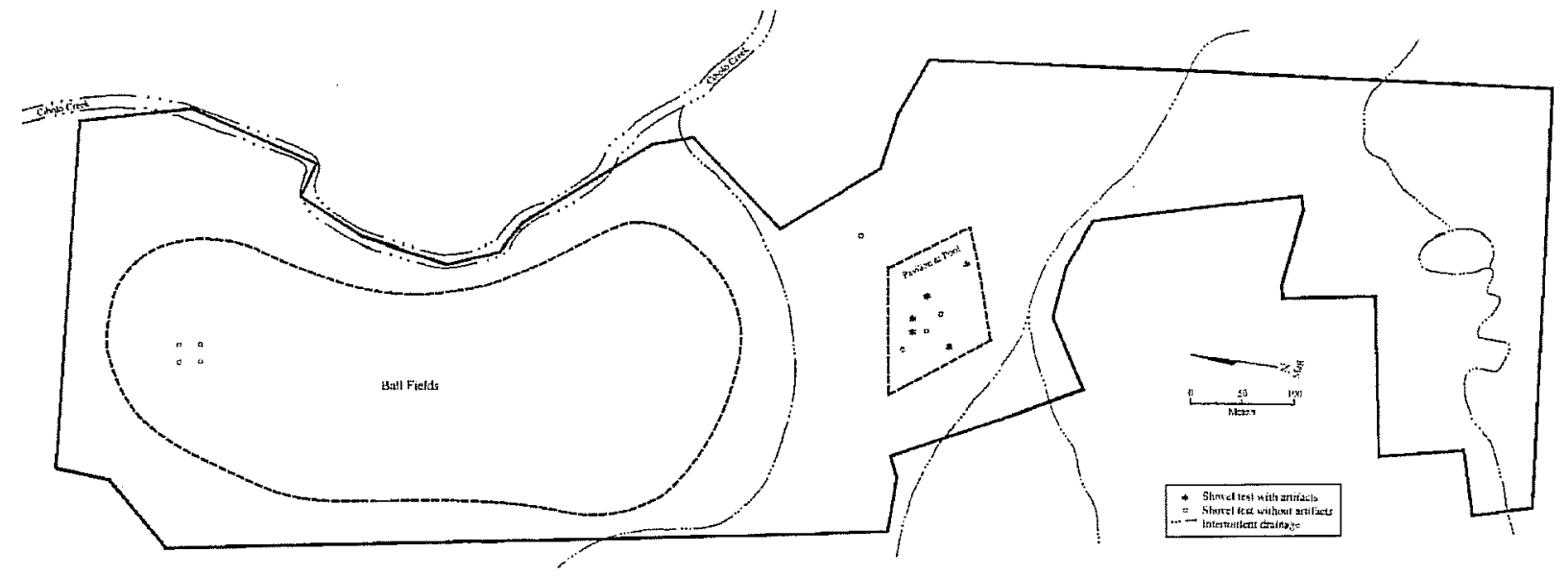

Figure 5. Planned construction of ball fields, pavilion, and pool in the project area.

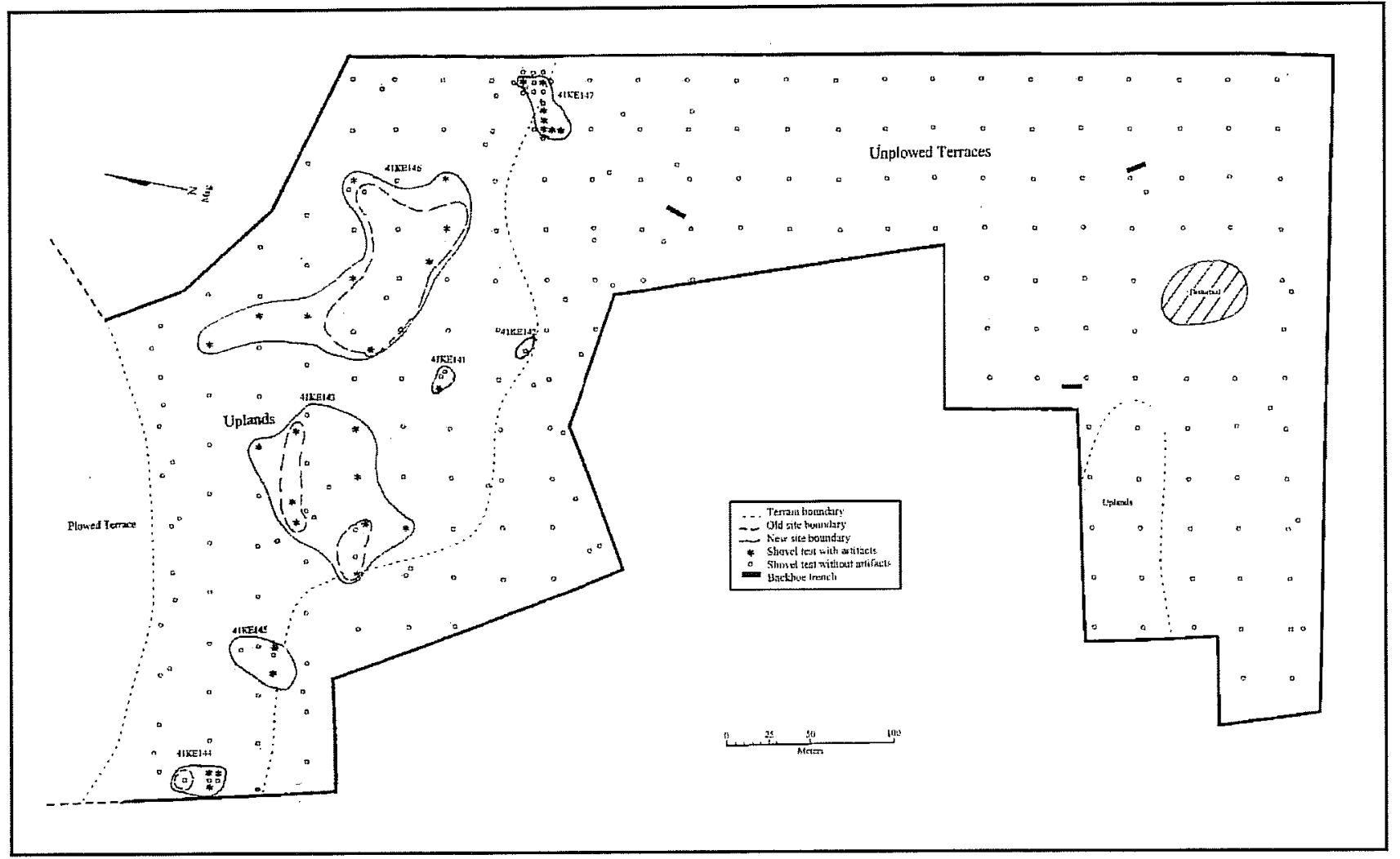

Figure 6. Shovel tests at 30-m intervals in the south 50 acres of the project area. 
boxes. Boxes were labeled with standard labels. Field notes, forms, photographs, and drawings were placed in labeled notebooks. Photographs, slides, and negatives were placed in archival-quality sleeves. All notebooks were stored in acid-free boxes. A copy of the site report and all computer disks pertaining to the investigation of the Northrup Park sites are stored in an archival box and curated with the field notes and documents. Artifacts, notes, documents, and photographs are permanently housed at the CAR.

\section{Survey Results}

\section{Shovel Test Sampling}

Five crew members, including the project archaeologist, excavated 213 shovel tests: 128 to an average depth of $40.7 \mathrm{~cm}$ in the terraces, and 85 to an average depth of $25.6 \mathrm{~cm}$ in the uplands. Fifteen (17.6 percent) of the shovel tests in the uplands contained artifacts, one ( $<1$ percent) in the terraces (Table 2).

The depth of those 29 tests placed in areas with a high potential for sites totaled $900 \mathrm{~cm}$. Using the average cm dug per hour (69.7) from the 30-m interval testing experiment, we can assume that the 29 tests took 13 person hours to conduct. No new sites were found and no previously identified site boundaries were extended as a result of the traditional testing strategy. The $30-\mathrm{m}$ interval testing strategy took 106 person hours, resulted in finding one additional site (41KE147), and extending the boundaries of three previously identified surface sites: 41KE143, 41KE144, and 41KE146 (Figure 6).

The additional work hours required to find one site in this 50-acre experiment provides a baseline from which to evaluate future projects. The data presented consider field crew time only, not the additional costs involved with driving time, vehicle maintenance, forms, artifact analysis, or publication of results. The density of surface sites in Texas over varied terrain can reasonably be predicted based on the results of numerous pedestrian surveys. However the effectiveness of using shovel test results for predicting the density of buried sites is unknown. A second project involving numerous shovel tests is offered for comparison. At the South New Braunfels Park project in south San Antonio, Bexar County, CAR conducted 164 shovel tests, each $50 \mathrm{~cm}$ deep (total $8,200 \mathrm{~cm}$ ) in systematic intervals over a 34.5-acre area. Again using the average $\mathrm{cm}$ dug per hour (69.7) from the $30-\mathrm{m}$ interval testing experiment, we can assume that testing at the South New Braunfels Project took over 117 hours. No sites were found as a result of shovel testing. Using the Northrup Park and South New Braunfels Park projects' data, the probability of finding a site as a result of systematic shovel testing is, at a minimum, one site for every 223 field hours.

Interval shovel testing during survey has redefined the boundaries of sites at Northrup Park and the upper Leon creek project area (Tennis and Hard 1995). However, a greater number of tests spaced at systematic intervals conducted during the actual site testing and recording phase would have accomplished the same at significantly less cost.

\section{The Prehistoric Sites}

Six prehistoric sites were found and documented during the pedestrian survey and one site was identified during the systematic shovel testing (Figure 5). The identification of seven sites in the project area exceeded the predicted number by one. The artifact inventories and other pertinent data are in the Artifact Analysis section and Appendix B. Six prehistoric sites are located exclusively in the uplands on Doss-

Table 2. Shovel Test Sampling Results

\begin{tabular}{|c|c|c|c|c|c|}
\hline $\begin{array}{c}\text { \# Crew- } \\
\text { members }\end{array}$ & $\begin{array}{c}\text { Test } \\
\text { Units }\end{array}$ & $\begin{array}{c}\text { Total cm } \\
\text { dug }\end{array}$ & $\begin{array}{c}\text { Total Hours } \\
\text { Worked }\end{array}$ & $\begin{array}{c}\text { Average cm } \\
\text { Dug Per Hour }\end{array}$ & $\begin{array}{c}\text { \# Units } \\
\text { with Artifacts }\end{array}$ \\
\hline 5 & 213 & 7,384 & 106 & 69.7 & $16(7.5 \%)$ \\
\hline
\end{tabular}


Brackett associated loamy clay soils, underlain by cemented limestone and chalky marl. One site (41KE147) sits on the edge of the uplands and extends downslope onto a terrace of Oakalla silty clay loam. Diagnostic artifacts present on the seven sites suggest the project area was occupied from possibly the Early Archaic through Late Prehistoric periods.

\section{KE141}

$41 \mathrm{KE} 141$ (Figure 7) is an open campsite with an ephemeral lithic scatter sitting on a gentle slope on the uplands. Live oak, juniper, and heavy grasses are the predominant vegetation. Running water exists $265 \mathrm{~m}$ to the northeast in Cibolo Creek, while an unnamed intermittent drainage lies $140 \mathrm{~m}$ to the southwest. Although the total number of artifacts is small, a relatively high frequency of cores suggests earlier stage reduction activities were more predominant than at the other five sites in the project area. The presence of fire-cracked limestone and chert suggest a possible short-term camping episode. Three shovel tests were placed on the site, one produced a flake at $0-10 \mathrm{~cm}$. The site has been heavily disturbed by erosion and a two-track road through its middle.

\section{$41 \mathrm{KE} 142$}

This open campsite with an ephemeral surface lithic scatter (Figure 8) sits on a gentle slope on the uplands, about $45 \mathrm{~m}$ south, and below 41KE141. Live oak, juniper, and heavy grasses are the predominant vegetation. Running water exists $310 \mathrm{~m}$ to the northeast in Cibolo Creek, while an unnamed intermittent drainage lies $12 \mathrm{~m}$ to the southwest. The base of a projectile point identified as a La Jita (Figure 9a) suggests an occupational period of late Middle Archaic (Collins 1995:Table 2; Johnson and Goode 1994). Although the total number of artifacts is small, the presence of the projectile point base, thinning flakes, and informal tools along with small numbers of fire-cracked chert and limestone imply that latestage lithic reduction actions were occurring during a possibly short-term camping episode. One shovel test to $20 \mathrm{~cm}$ below surface produced no evidence of buried cultural material. A depression on the southeast end of the site defines where a historic trash dump (see below) has been bulldozed out and hauled away. An unimproved two-track road cuts through the middle of the site.

\section{KE143}

$41 \mathrm{KE} 143$ is a lithic scatter (Figure 10) sitting on a broad, flat portion of the uplands $210 \mathrm{~m}$ southwest of extant water in Cibolo Creek, and $190 \mathrm{~m}$ northwest of an unnamed intermittent drainage. Live oak, juniper, and heavy grasses are the predominant vegetation. Cores, exterior flakes, and thinning flakes provide evidence that a broad spectrum of lithic reduction occurred at this site. The presence of one fire-cracked limestone fragment and seven fire-cracked chert fragments on the surface suggest the possibility that more may be buried. Initially, 16 shovel tests were placed on the site; nine produced artifacts, suggesting that a possibly intact cultural deposit with a depth of up to $30 \mathrm{~cm}$ may lie below the surface. The site has been moderately disturbed on the surface by an unimproved two-track road that cuts through its middle. CAR later returned to the site and placed an additional 16 shovel tests along the southern edge of the site which was to be impacted by construction of a new road. Two tests contained one flake each in the upper $10 \mathrm{~cm}$.

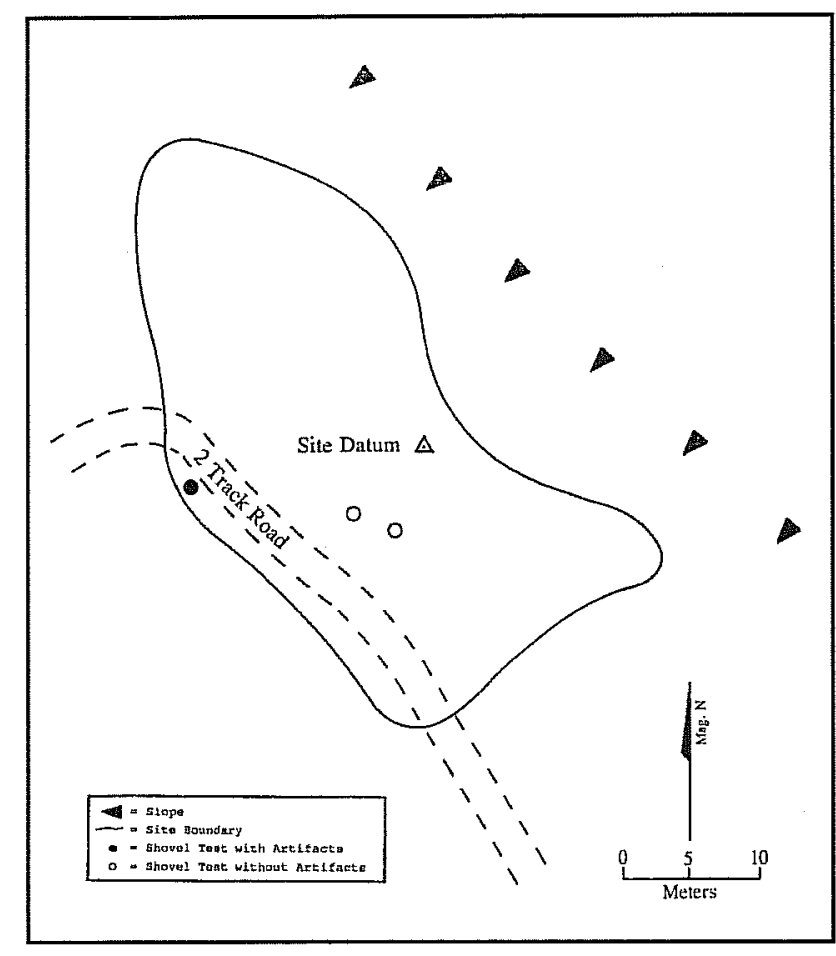

Figure 7. Site map, 4IKE141. 

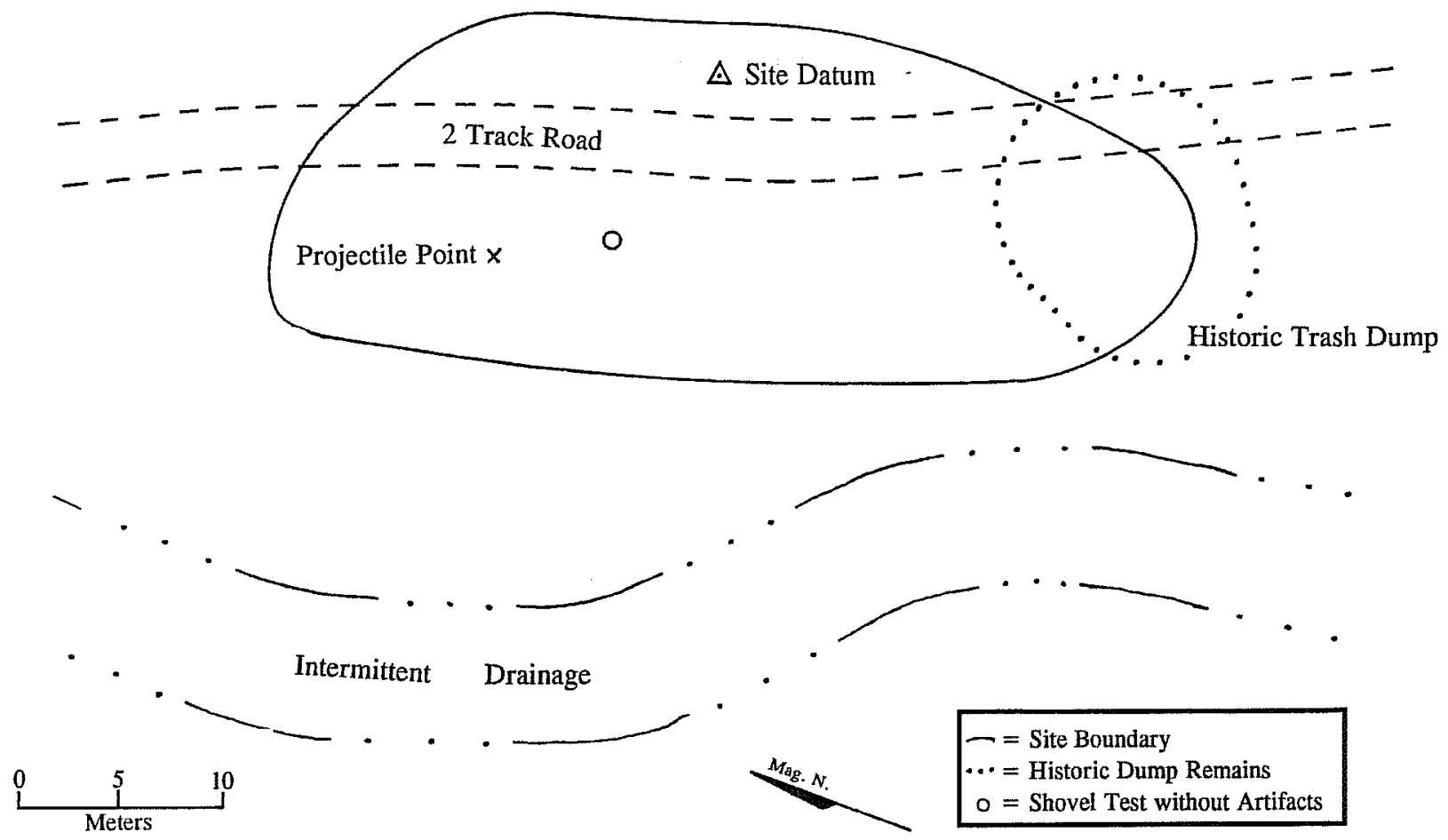

Figure 9. Stone tools. a: La Jita point base, 41KE142;

Figure 8. Site map, 4lKE142.

b: formal tool, $41 \mathrm{KE} 145$; c: thin biface, $41 \mathrm{KE} 145$;

d: preform, 41KE145; e: Frio point, $41 \mathrm{KE} 146$;

f: obsidian flake, $41 \mathrm{KE} 146$.

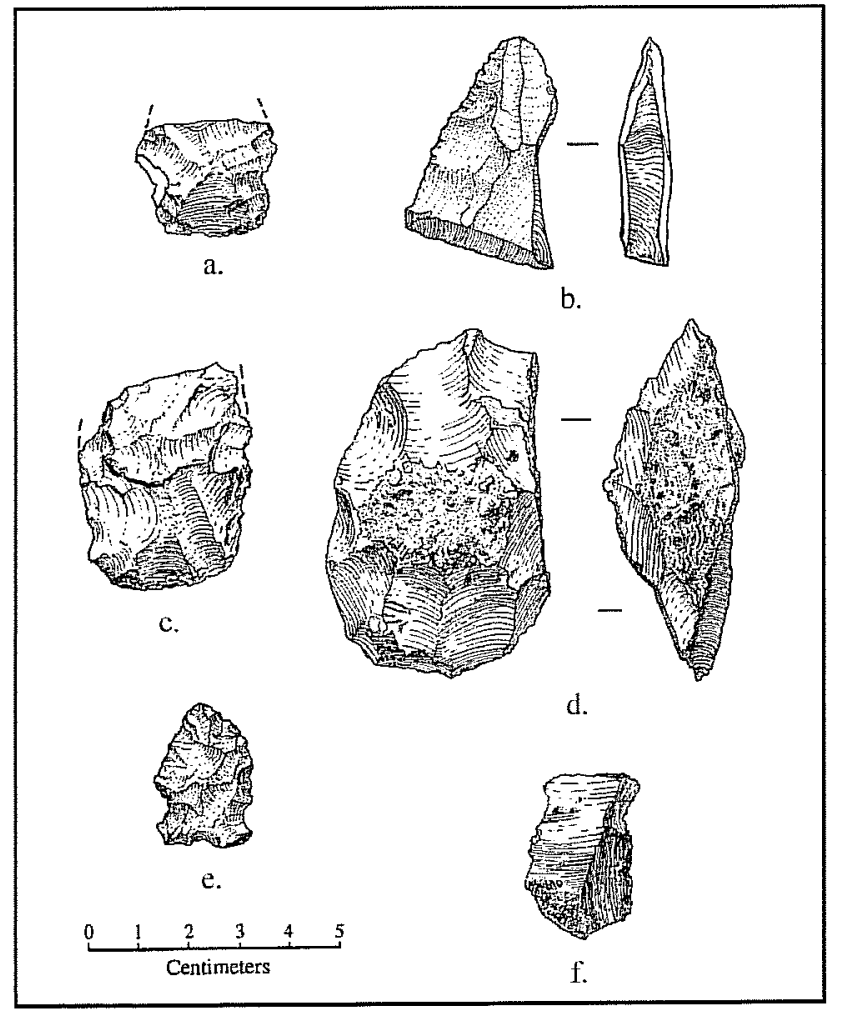

Figure 10. Site map, $41 K E 143$.

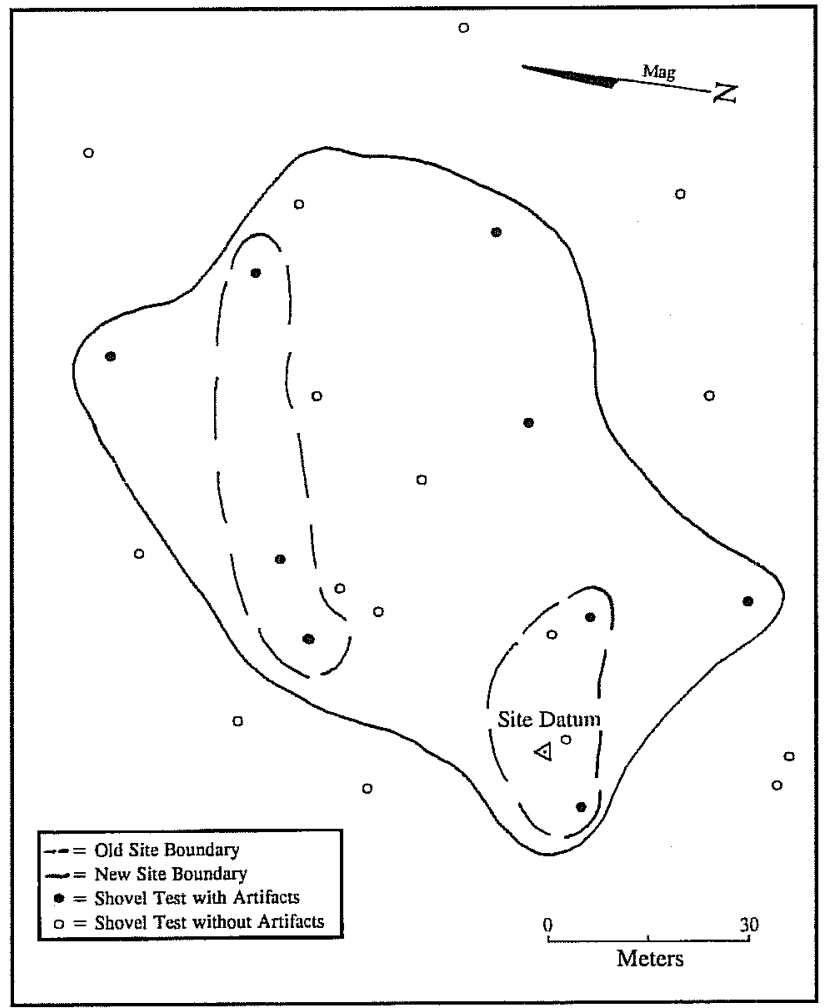




\section{KE144}

$41 \mathrm{KE} 144$ is an open campsite (Figure 11) with an ephemeral lithic scatter sitting on a ridge on the uplands, overlooking a broad flat terrace on Cibolo Creek $400 \mathrm{~m}$ to the northeast, and north of an unnamed intermittent drainage $50 \mathrm{~m}$ to the south. Live oak, juniper, and heavy grasses are the predominant vegetation. Although few in quantity, the stone artifacts and fire-cracked chert and limestone suggest early-stage reduction activities occurred during a shortterm campsite occupation. Six shovel tests were placed on the site; three produced artifacts to a depth of up to $10 \mathrm{~cm}$. The site has been moderately disturbed by natural means and a two-track road.

\section{KE145}

41KE145 an open campsite with an ephemeral lithic scatter sitting on a ridge on the uplands (Figure 12), overlooking a broad flat terrace on Cibolo Creek $375 \mathrm{~m}$ to the northeast, and north of an unnamed intermittent drainage $60 \mathrm{~m}$ to the south. Live oak, juniper, and heavy grasses are the predominant vegetation. Some stone artifacts present on the surface

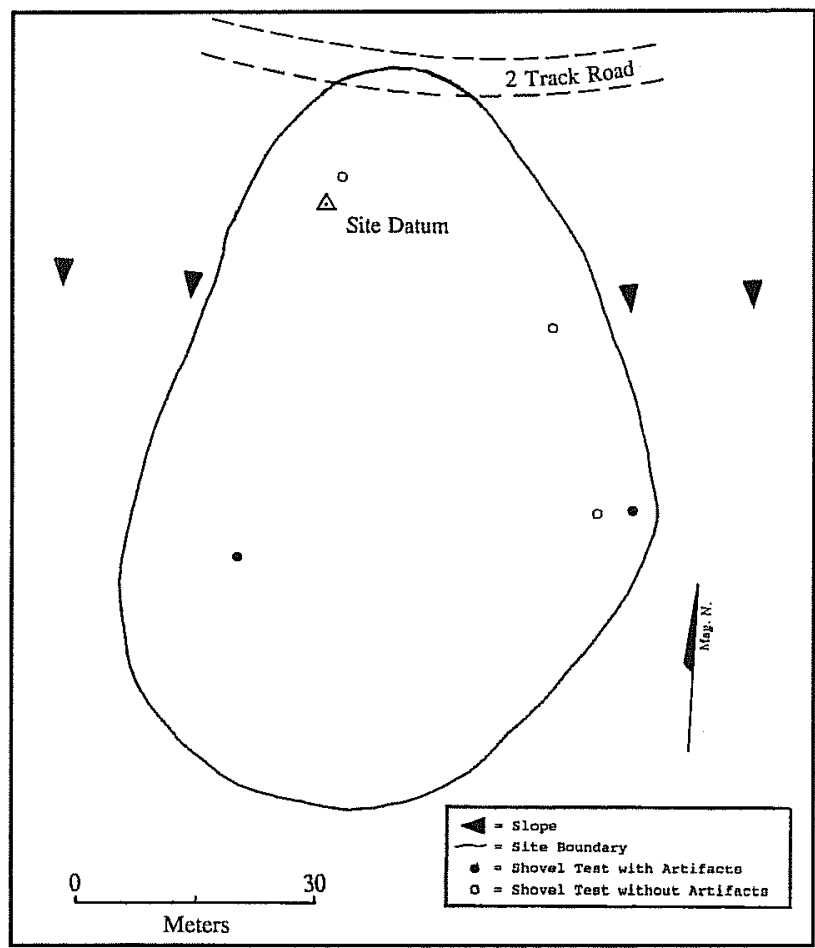

Figure 12. Site map, 41 KE145.

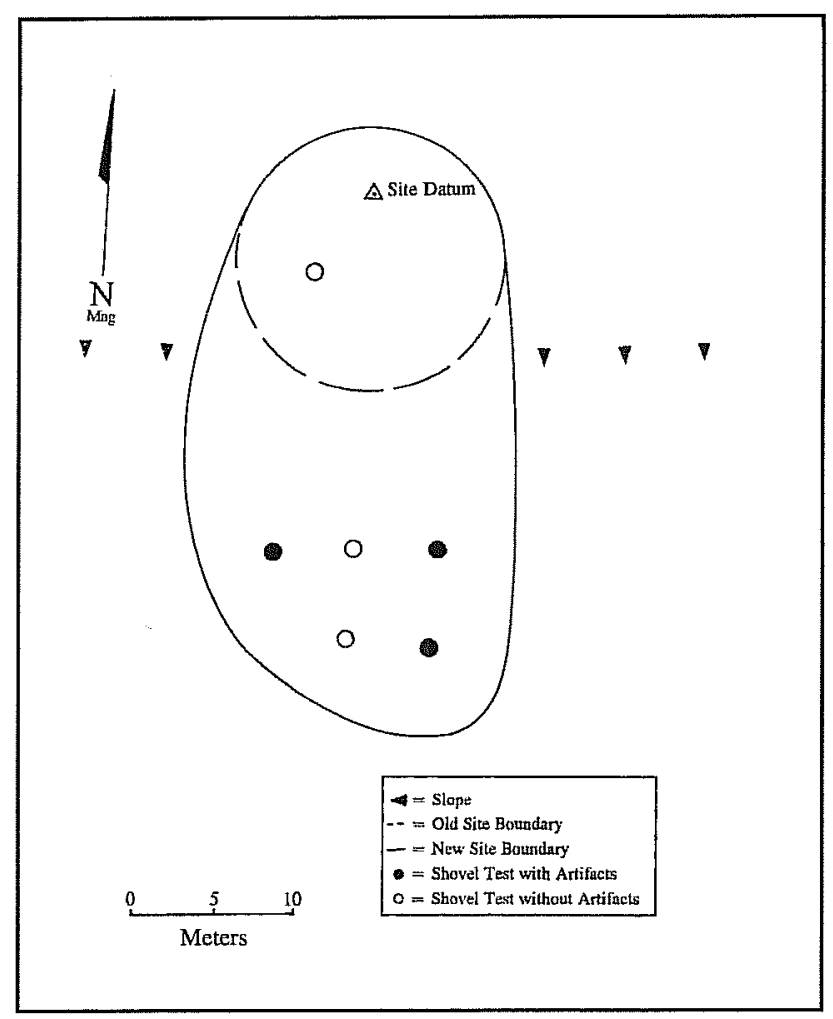

Figure 11. Site map, $41 K E 144$.

show signs of heat alteration. While a few of the artifacts are much more heavily patinated than those on the other six sites in the project area, the remaining exhibit varying degrees of patination. Collins et al. (1990:13-15) argue that Early through Late Archaic occupations become a palimpsest on higher elevation sites as artifacts become mixed when the same sites are used through time and little or no deposition occurs. A stone tool found here (Figure 9b) shows signs of three episodes of patination and appears to have been heavily modified; the snapped distal end of what may have been a Clear Fork uniface (Turner and Hester 1993:248-249) has been modified for use as a burin on one edge, and unifacially resharpened for use as a scraper on the other. In addition, the proximal end shows evidence of use wear. Also found at the site were a crude thin biface (Figure 9c) and a chert preform with macroscopic fossil inclusions (Figure 9d). The possible Clear Fork fragment and heavily patented material on the site suggests a possible Early Archaic occupation (Turner and Hester 1993:248). Although limited in quantity, the presence of firecracked limestone and less reduced lithic material suggests that early stage reduction activities occurred 
during short-term camping periods. Five shovel tests were placed on the site; two produced artifacts to a depth of $10 \mathrm{~cm}$. The site has been heavily disturbed by erosion, a two-track road on its north edge, and minor construction activities apparently from children playing in the area.

\section{KE146}

This largest of the project-area sites is an open campsite (Figure 13) sitting on a broad, flat portion of the uplands $210 \mathrm{~m}$ southwest of Cibolo Creek, and $190 \mathrm{~m}$ northwest of an unnamed intermittent drainage. Live oak, juniper, and heavy grasses are the predominant vegetation. A Frio point (Figure 9e) found on the surface suggests at least a late Late Archaic (ca. 1200 B.P.) occupation. An obsidian flake (Figure 9f) recovered from the surface and subjected to trace element analysis was determined to be from near Santa Fe, New Mexico.

The presence of a relatively high quantity of firecracked limestone and chert in association with the lithic debris implies that a full range of lithic reduction

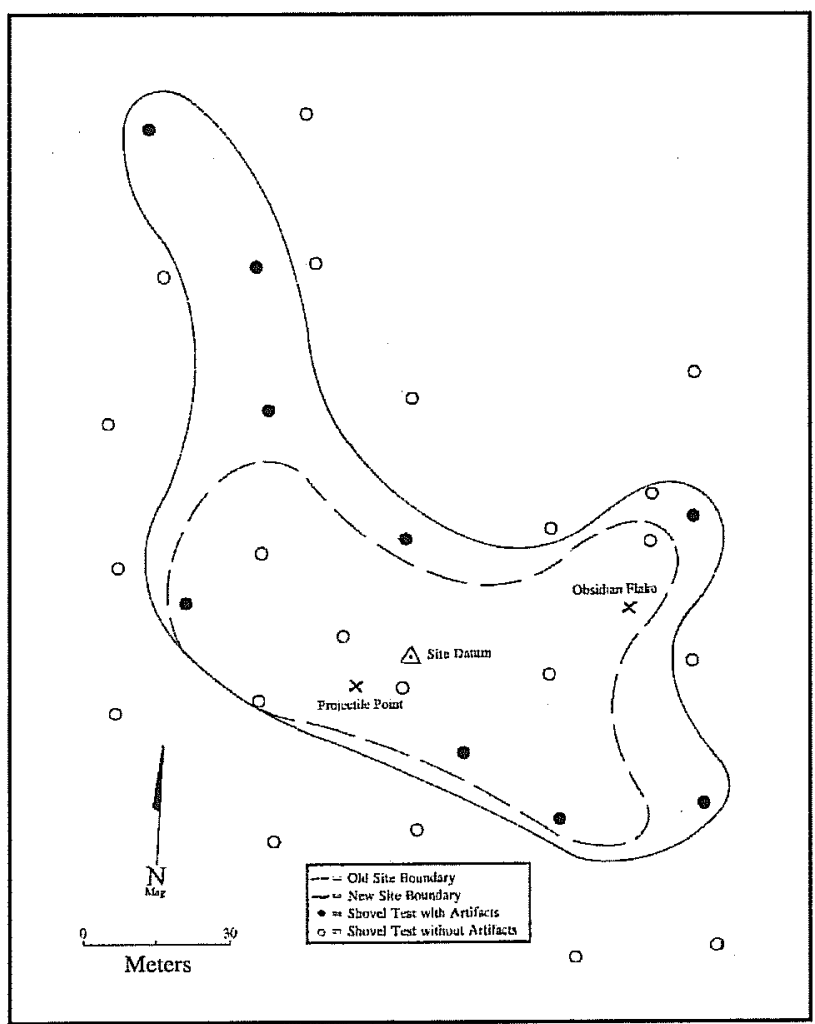

Figure 13. Site map, $41 K E 146$. activities occurred while the inhabitants were occupying the campsite. Approximately 90 percent of the chert appeared to have undergone thermal alteration. The possibility of intact cultural deposits is offered by nine of sixteen shovel tests on the site which produced chert flakes up to $30 \mathrm{~cm}$ below the surface.

\section{KE147}

This site was found as a result of systematic interval shovel testing. Only an interior flake and a tested cobble were observed on the surface, however seven of 19 shovel tests contained artifacts as deep as 30 $\mathrm{cm}$. $41 \mathrm{KE} 147$ straddles the edges of an uplands limestone outcropping and an alluvial terrace along an in-

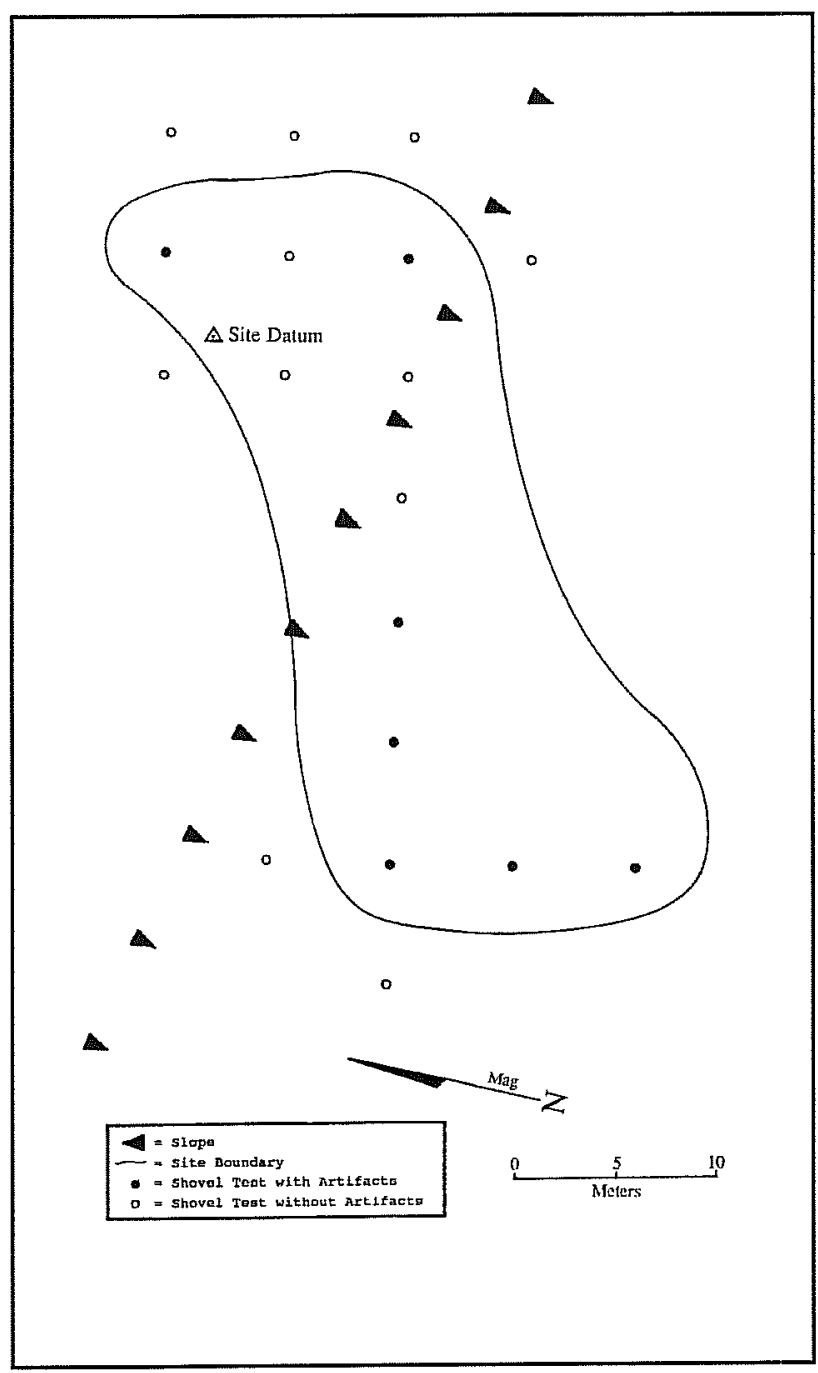

Figure 14. Site map, $41 K E 147$. 
termittent drainage (Figure 14). A small core and several small flakes $(<5 \mathrm{~cm})$ were recovered from the shovel tests to a depth of $30 \mathrm{~cm}$ within the alluvium deposits. The integrity and age of this site is unknown. Moderate disturbance from erosion has occurred.

\section{Artifact Analysis}

\section{Introduction}

This section describes the analysis of the recovered artifacts. One hundred thirty-six historic and 319 prehistoric chipped-stone artifacts were recovered during the investigations. No ground or battered stones were found.

\section{Artifact Types}

\section{Chipped Stone}

Three hundred nineteen chipped-stone artifacts were recovered during the project. During the cataloguing process, these were subdivided into the following classes: projectile points (2), bifaces (17), unifaces (7), cores (211), and unmodified debitage (182). Each class was analyzed according to a variety of attributes which provided a thorough technological and morphological characterization of the assemblage and allowed for consistent comparisons to be made between collections from different sites in the project area. The type and quality of raw material used in the manufacture of each chipped stone tool was also recorded, providing another variable which could then be compared across site assemblages and artifact class. The attributes for each artifact class are defined below.

\section{Projectile Points}

The following attributes were recorded for projectile points: raw material type, raw material quality, burning, projectile point subgroup, projectile point type, serration, beveling, completeness, break type, maximum length, blade length, blade width, haft length, neck width, base width, maximum thickness, and weight.
Only two projectile points were recovered, a Transitional Archaic Frio point (Turner and Hester 1993:122) and a Middle Archaic La Jita proximal fragment (Johnson and Goode 1994). La Jita dart points are commonly found on the southeast edge of the Edwards Plateau (Turner and Hester 1993:140). The La Jita point type was first found at the La Jita site in Uvalde County (Hester 1971:74, Figure 11), others have since been found in Kendall County at 41KE49 (Kelly and Hester 1976a). Black and McGraw (1985:117) suggest the La Jita point is diagnostic of the Early Archaic, while Johnson and Goode (1994) date La Jita to late Middle Archaic, about 4500 B.P., consistent with Collins's (1995:Table 2) Central Texas chronology of between 4500 and 4000 B.P.

The La Jita point fragment (Figure 9a) recovered from the surface at $41 \mathrm{KE} 142$ is made from fine-grained brown chert. Its surface is heavily patinated. It has rounded shoulders and a slightly rounded and convex, expanded stem produced by shallow side notches and rounded corners. Some basal thinning of the stem has occurred and one edge of the stem appears to be slightly beveled. Its stem width and length are $2.3 \mathrm{~cm}$ and $1.2 \mathrm{~cm}$ respectively; shoulder width is $2.8 \mathrm{~cm}$. The point has been broken in midsection from use. There is no evidence of burning, serration, or resharpening.

Frio dart points are commonly found in central and south Texas as well as the Lower Pecos and TransPecos areas of Texas (Turner and Hester 1993:122). Frio points have been found close to Northrup Park, on Camp Bullis in northern Bexar County (Gerstle et al. 1978). Temporally, the Frio has been identified with the Transitional Archaic (Turner and Hester 1993:122), ca. $2150-1350$ B.P. Collins (1995:Table 2) suggests that the Frio is best placed in chronological context at the Loeve Fox site (Prewitt 1974), between ca. 1200 and 1500 B.P., near the end of the Late Archaic.

The Frio point (Figure 9c) recovered from the surface at $41 \mathrm{KE} 146$ is made of fine-grained, brown chert. Although it has been heavily resharpened on both lateral edges, and a post-depositional break is the cause for a missing rounded shoulder, it is a complete specimen measuring $2.9 \mathrm{~cm}$ in length, $1.9 \mathrm{~cm}$ in maximum width, $1.9 \mathrm{~cm}$ from basal ear to basal ear, and $.5 \mathrm{~cm}$ in 
maximum thickness. It has a slight basal indentation of $.13 \mathrm{~cm}$. There is no evidence of burning, serration, or beveling.

\section{Bifaces}

Artifacts that are flaked on both sides of the same lateral edge are classified as bifaces. Seventeen bifaces (excluding projectile points) were collected during the project. For each specimen, the following attributes were recorded: raw material type, raw material quality, burning, percentage of cortex remaining, length, width, thickness, tool completeness, blank type, stage of reduction, shape, break type, and evidence for tool recycling. The first three attributes were coded as described above for projectile points. The other attributes are discussed below.

Ten (58.8 percent) of the bifaces were made of what was identified as Edwards or Glen Rose chert, and seven (40.2 percent) from highly fossiliferous chert of unknown origin. None of the material used was quality fine-grained chert with no inclusions, nine (52.9 percent) were made from fine-grained chert with coarse-grained inclusions, and eight (47.1 percent) were made from coarse-grained chert. Four (23.5 percent) of the specimens exhibited some evidence of burning. Thirteen (76.5 percent) of the bifaces contained 1-50 percent cortex, three (17.6 percent) contained 51-99 percent cortex, and one (5.9 percent) had no cortex.

Ten of the bifaces (58.8 percent) were complete specimens, two (11.8 percent) were longitudinal portions, one (5.9 percent) was a medial, and four were indeterminate fragments. Twelve 17 (70.6 percent) could be measured for maximum length, which ranged from $5.1-10.2 \mathrm{~cm}$. The mean length was $7.7 \mathrm{~cm}$. Fifteen (88.2 percent) bifaces could be measured for maximum width, which ranged from $2.9-7.9 \mathrm{~cm}$. The mean width was $5.5 \mathrm{~cm}$. Fifteen could be measured for maximum thickness, which ranged from 1.4-3.0 $\mathrm{cm}$. The mean thickness was $2.2 \mathrm{~cm}$.

Seven (41.2 percent) of the bifaces were made from flakes, seven (41.2 percent) from nodules, and three (17.6 percent) from an indeterminate form. Sixteen (94.1 percent) had been discarded after being worked in an early stage of reduction, while the remaining one (5.9 percent) had been worked to a middle stage. One (5.9 percent) had been worked sufficiently to determine its intended ovate shape, three (17.6 percent) to a pointed-ovate, and one (5.9 percent) to a triangular shape. The intended shape of the remaining 12 (70.56 percent) was indeterminate.

Seven (41.2 percent) bifaces had been broken. Of these, four (57.1 percent) were broken during manufacture, while the remaining three were broken by indeterminate causes. None of the bifaces recovered showed signs of burning or heat treating.

\section{Unifaces}

Artifacts that are flaked on one surface are classified as unifaces. Six unifaces were collected during the testing project. For each specimen, the following attributes were recorded: raw material type, raw material quality, burning, percentage of cortex remaining, maximum dimension, blank type, tool completeness, degree of retouch, location of modification, edge shape, and evidence for tool recycling. The first three attributes were coded as described above for projectile points.

Of the six unifaces recovered, five were made from Edwards or Glen Rose chert, and one was made from a highly fossiliferous chert from an unknown source. Four of the unifaces (66.7 percent) were made from fine-grained chert with coarse-grained inclusions. The remaining two (33.3 percent) were made from coarsegrained chert. Only one of the six (16.7 percent) exhibited evidence of burning.

All six unifaces were made from flakes. Five of six (83.3 percent) were complete, and the remaining specimen (16.7 percent) was an indeterminate portion. Five of the six ( 83.3 percent) could be measured for maximum dimension, which ranged from $4.2 \mathrm{~cm}$ to $7.1 \mathrm{~cm}$. The mean length was $6.2 \mathrm{~cm}$. Four of six $(66.7$ percent) still had from 1-50 percent of the cortex remaining, and the other two (33.3 percent) had no cortex. Three of six (50 percent) exhibited a minimal degree of retouch, and the remaining three (50 percent) had been formally retouched. Three ( 50 percent) had been modified on their left lateral edges, two ( 33.3 percent) 
on their distal ends, and one (16.7 percent) had both lateral and distal modification. Four of the six (66.7 percent) had convex edges, one (16.7 percent) had a pointed edge, and the remaining one (16.7 percent) had an irregular edge. None of the unifaces exhibited evidence of recycling.

\section{Cores}

Two hundred fifty-one cores and core fragments were recovered during the testing project. Only complete cores were analyzed, reducing the number from 251 to 84 ( 33.5 percent). For each specimen, the following attributes were recorded: raw material type, raw material quality, evidence of burning, percentage of cortex remaining, maximum dimension, number of flake scars, flake scar direction, and evidence for tool recycling. The first four attributes were coded as described above for bifaces and unifaces. Flake count excluded small hinge and step fractures resulting from efforts to prepare striking platforms. Flake direction was classified as either unidirectional, bidirectional, multiple, or indeterminate. Specimens with bifacial flaking from the same edge were counted as bifaces, not cores. Tool recycling was coded as described for unifaces and bifaces.

Twenty-one ( 25.0 percent) of the 84 analyzed cores were either Edwards or Glen Rose chert; the remaining 63 (75 percent) were a highly fossilized chert of unknown origin. Only two (2.4 percent) were of finegrained material with no inclusions. Fifteen (17.9 percent) were fine-grained with coarse inclusions, and the remaining 69 were of coarse-grained material. Seventy-seven ( 91.7 percent) of the cores were complete, so maximum dimensions could be obtained. Maximum length ranged from $5-20 \mathrm{~cm}$, with a mean of $10.3 \mathrm{~cm}$.

Forty-three (51.2 percent) had from 51- 99 percent cortex, and the remaining 41 (48.8 percent) had from 1-50 percent cortex. The number of flake scars ranged from one to 13 , with a mean of 3.2. Thirty-four ( 40.5 percent) of the cores exhibited flake scars in only one direction, 25 (29.8 percent) had scars in two directions, 20 (23.8 percent) had flake scars in more than two directions, and the remaining five (5.9 percent) were damaged to the extent that the flake direction was indeterminate.

\section{Unmodified Debitage}

The largest category of chipped stone recovered during the project was unmodified debitage. The goal of the analysis of this category was to reconstruct the types of reduction strategies represented in the debitage recovered at Northrup Park. The process was streamlined by analyzing only complete flakes and by using an approach in which each is assigned to a predefined flake type. Prior to the analysis of the Northrup Park material a series of flake types which are defined on the basis of a list of attributes that are most characteristic of specific reduction techniques were determined. The method employed during the Northrup Park analysis results in the immediate identification of flake type.

The selection of complete flakes with intact platforms reduced the sample from 182 pieces of debitage to 73 . For each complete flake the following attributes were recorded: raw material type, raw material quality, maximum dimension (rounded up to nearest centimeter), platform faceting, amount of dorsal cortex, and flake type. Platform faceting was characterized as either single, double, multiple $(3+)$, or corticate. The amount of dorsal cortex was quantified as either 100 percent (primary flake), less than 100 percent but greater than 0 percent (secondary flake), or 0 percent (tertiary flake) of the surface area of the dorsal side of the flake. Flake types recognized were biface manufacture, platform preparations and/or core preparation, and sequence. These are defined below.

\section{Biface Manufacture Flakes}

These flakes are defined as primary and secondary flakes having moderate to large dorsal flake scar ridges and with minimal to considerable longitudinal curvature. The striking platforms on this type range from single- to multifaceted, although single and double faceting are most common. These flakes are usually removed with a hard hammerstone or large billet, and the dorsal flake scarring is indicative of sequential flake removals and flake removals from opposite edges (Mehalchick et al. 1996). 
Platform Preparation and/or

\section{Core Preparation Flakes}

Platform and core preparation flakes are highly variable in size, shape, amount of dorsal cortex, and platform faceting, but they all represent an attempt to prepare a platform or core for subsequent flake removals. Size and platform faceting are dependent upon the stage of reduction during which they were removed and the size of the parent material which may be a core or artifact. Likewise, shape is dependent on the type of core from which they were removed. The amount of dorsal cortex is also highly variable, ranging from $0-100$ percent, depending on the stage of reduction (Mehalchick et al. 1996).

\section{Sequence Flakes}

Sequence flakes are indicative of a particular core reduction strategy in which a cobble is first split lengthwise and then flakes are removed in sequence beginning at one end of the core. Flakes removed in this fashion show "direct superposition of positive and negative bulbs of percussion on the interior and exterior flake surface respectively" (Jelinek et al. 1971). This method of flake removal may have been useful in an environment where raw material was commonly available as tubular cobbles rather than as tabular or spherical cobbles, although it can also be used to reduce split cobbles (Houk and Nickels 1997:199).

\section{Unique Items}

\section{Obsidian Flake}

The distal end of an obsidian transverse snapped bifacial thinning flake (Figure 9f) with approximately 10 percent cortex was found on the surface of 41KE146. Because obsidian sources are not known in Texas (Hester 1988:27; Hester et al. 1985), obsidian artifacts are not commonly found on Texas archaeological sites. X-ray fluorescence and neutron activation analysis performed on an obsidian point base from Kincaid Rockshelter in Uvalde County, south-central Texas, determined that the raw obsidian material contained trace elements similar in quantity to a geologic source near Queretaro, Mexico, nearly $1,000 \mathrm{~km}$ south of Uvalde County (Hester et al. 1985:146-150).
Ongoing analysis of obsidian found in Texas is being conducted as part of the Texas Obsidian Project (TOP). The flake from $41 \mathrm{KE} 146$ was submitted to Thomas R. Hester at the Texas Archeological Research Laboratory for inclusion in TOP and was determined to be from the Jemez Mountains north of Santa Fe, New Mexico (Appendix C).

\section{Clear Fork Uniface}

Clear Fork gouges are commonly found at sites in the middle of the state from north to south, and even into northeastern Mexico. Although their form changes slightly through time, they are diagnostic of the Paleoindian, Early Archaic, and Middle Archaic intervals (Turner and Hester 1993:246-249).

The possible Clear Fork uniface found on the surface at 41KE145 (Figure 9b) shows signs of three episodes of patination and appears to have been heavily modified. The snapped distal end has been modified for use as a burin on one edge, and unifacially resharpened for use as a scraper on the other. In addition, the proximal end shows evidence of use wear. It is made from tan, fine-grained chert and exhibits a heavy degree of patination. Its distal end has been broken off during manufacture.

\section{Isolated Finds}

Fifteen nondiagnostic artifacts recorded as isolated finds were found at the project area. Four were found in the northeast corner of the open plowed field. Other fragments of naturally fractured chert were noted in the same area, at the base of a low hill on private property. A core was observed on the side of the same hill, outside the project area, in the IH-10 right-of-way. It thus appears likely that there is an archaeological site on the hill and chert debris is eroding downslope into the project area. Eleven isolated finds were recorded on the uplands and one in an intermittent drainage adjacent to the uplands. 


\section{Historic Artifacts}

Isolated historic trash was found and examined across the project area. No foundations of permanent structures were observed during the survey; a pole-barn and a small wood and tin animal shelter were observed in the uplands area.

An ephemeral accumulation of historic debris was present on the southern edge of $41 \mathrm{KE} 142$ (Figure 8). An informant related that a trash dump once here had recently been declared to contain toxic material. Therefore the majority of the trash had been cleaned up with a bulldozer and hauled away (Christopher Turk, personal communication 1996). An unimproved two-track road cuts through the middle of the site. Selected pieces from the small amount of historic material remaining was analyzed, and suggests the dump was used during the late-nineteenth and earlytwentieth centuries. Selected items collected for analysis are described below.

\section{Condiment bottle neck (ca. 1850-1900)}

This aqua bottle neck (Figure 15a) has an oil finish lip and a long tapered collar (Watson 1965:40), typical of bottles used for preserving liquid kitchen condiments, and possibly bitters (Illinois Glass Company 1904:43). Prior to the 1850s, most bottles were aqua, with amber becoming the favored color by 1870 (Watson 1965:39). This bottle neck is most likely post1850 , as it has two seams up the side, stopping short of the lip. This configuration is typical of bottles hand blown into a post-bottom mold, a form popular during the last half of the nineteenth century (Munsey 1970:32, 39).

\section{Stoneware sherd (ca. 1860-1900)}

Stoneware is a utilitarian ware and was commonly used in Texas kitchens and dairies from 1860 through 1950 (Greer 1981:13-26). The stoneware sherds at 41BX1124 have a Bristol white glaze on the outside and an Albany slip on the inside, and are most likely pre-1900. Albany Slip became less favored, and was eventually replaced by Bristol Glaze. The latter was typically in household use by 1900 (Greer 1981: 170-171).
Whiteware sherds (ca. 1860s or later): Whiteware is a highly fired refined clay with a vitreous glaze. It was often hand painted or spattered with a cut sponge for decoration (Dial 1992:38). One whiteware sherd found at the site is undecorated, with a clear, shiny glaze. Whiteware was commonly imported to America from Britain during the 1800 s, but the demand for the undecorated type increased significantly in America by 1860. This type became a common tableware setting for middle class families around San Antonio after the 1860s, replacing pewter and wooden wares (Fox et al. 1989:45). One other whiteware sherd is blue hand-painted underglaze, a style which, although a little more expensive than plain undecorated, was a popular import item during the early 1800 s.

\section{Single-action spring hinge (ca. 1902 or later)}

This decorated iron hinge (Figure 15b) would have been commonly used on a screen door. While no specific date was obtainable from examination of the spring, it is typical of the style offered in the Sears, Roebuck catalog (Avory 1969).

\section{Medicine bottle (ca. 1906-1930s)}

This round, clear glass bottle (Figure 15c) has what is called a "prescription lip," designed for a cork stopper and commonly found on glass liquid containers during the late-nineteenth and early-twentieth centuries (Illinois Glass Company 1903:4). Although the cork stopper had shrunk, it was recovered from inside the bottle. The stopper and suction machine cutoff scars indicate it was probably manufactured between 1906, when suction machine technology developed (Munsey 1970:40), and the 1930s when continuous-thread caps became predominant (Miller and Pacey 1985:45-46). The maker's mark could not be identified.

\section{Spent ammunition cartridge (ca. 1918)}

This is a high calibre brass, centerfire, rimless rifle cartridge. Although the first centerfire cartridge was developed in 1866 , rimless cartridges were not developed until the early twentieth century. The rimless design allowed them to be easily fed from clip and belt magazines developed by the military at that 


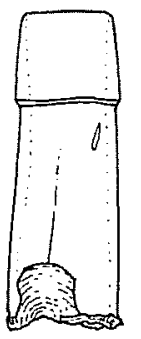

a.

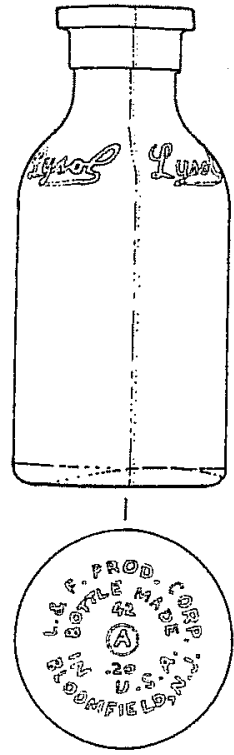

e.

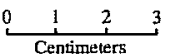

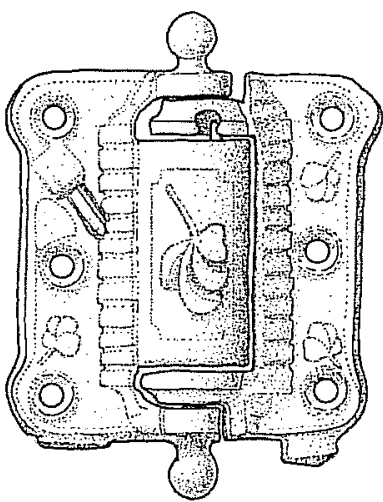

b.

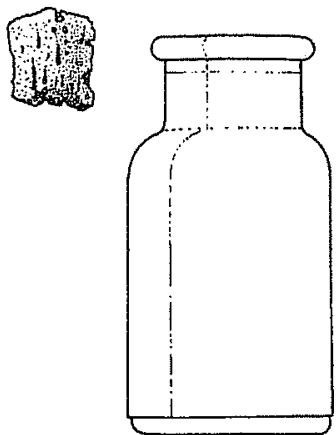

c.

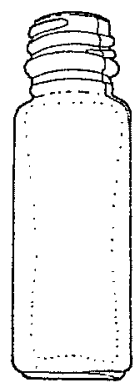

d.

Figure 15. Historic artifacts from $41 K E 142$. a. condiment bottle neck; b. single-action spring hinge; $c$. medicine bottle; d. condiment bottle; e. Lysol bottle.

time. Most rifle cartridges manufactured today are of the centerfire, rimless type (Winchester-Western 1964:64). Inscribed lettering-A F 18 - on the base identifies the cartridge as .276 caliber, manufactured at the Frankford Arsenal in 1918. This type of cartridge

was used in the experimental Garfield and semiautomatic Pederson rifles (Logan 1959:112).

\section{Condiment bottle (ca. 1930s or later)}

This small, square, clear glass bottle (Figure 15d) a continuous-thread design. The latter became the standard method of capping bottles in the 1930s and is still used today (Miller and Pacey 1985:45-46).

\section{Lysol bottle (ca. 1938-1969)}

This round, amber disinfectant bottle (Figure 15e) has the word "Lysol" embossed on the side. This bottle also has a prescription lip designed for a cork stopper. Cork and glass stoppers were commonly used until the continuous-thread design became standard. The bottom has suction-machine-cutoff scars; suction machine technology was not well developed until after 1906 (Munsey 1970:40). Embossing on the bottom provides evidence that the product was distributed by the L\&F Production Corporation of Bloomfield, New Jersey. The maker's mark on the bottle reveals that this type of bottle was manufactured by the Armstrong Cork Company of Lancaster, Pennsylvania, between 1938 and 1969 (Toulouse 1971:24-25). A “42” embossed on the bottom is likely the year (1942) this particular bottle was manufactured.

\section{Analysis of the Prehistoric Artifact Data}

The survey and limited testing within Northrup Park have offered a broad picture of the lithic technology present at six of the seven sites. Although admittedly problematic because of possible mixing of occupations and somewhat biased due to limited surface visibility, the surface assemblages can be analyzed to define lithic reduction activities. In order to do so, one must assume that the chipped stone surface assemblages present at the site today are associated with and represent the tool making activities that occurred at those sites in the past. 
Presenting the data in statistical format allows us to easily identify and further evaluate the differences and similarities in lithic assemblages among the six sites. Contingency tables examining cores, flakes, bifaces, and unifaces are presented for five of the seven Northrup Park sites. 41KE146 was not 100-percent surface collected and $41 \mathrm{KE} 147$ had only two core fragments on the surface; therefore, these two sites are not included in the analysis. This study uses adjusted residuals, a type of analysis devised for contingency tables which compare the observed values to expected values as defined by a chi-square test.

Adjusted residuals measure the observed variability from the expected pattern. The adjusted residual is a value that has the same distribution as a typical $z$-score for a normal probability distribution (Haberman 1978; Norusis 1993; Thomas 1986). For purposes of this analysis, a 0.1 level of significance was used, which equates to a 1.645 cutoff value of the adjusted residual. Thus, an adjusted residual that is greater or less than \pm 1.645 is considered significant.

Lithic debitage was examined with contingency tables for the amount of cortex, flake type, flake length, and the number of facets on the flake platform. These four attributes identify the degree to which cores, quarry blanks, or preforms were being reduced at each site. In addition, flake type and platform faceting provide an indication of the type of tools being manufactured.

Table 3 provides an analysis of the amount of cortex on flakes from each site. The observed values are the actual flake count by amount of cortex. The percentile figures are the relative frequencies of cortex amounts on flakes from the five sampled sites. On average, one would expect to see 39.7 percent primary, 45.2 percent secondary, and 15.1 percent tertiary flakes at each of the five sites. Examining the adjusted residuals where an expected value exceeds a 0.1 level of significance, the table shows that the number of tertiary flakes found at $41 \mathrm{KE} 143$ is significantly greater than expected. This observation suggests that more late-stage reduction activities were occurring at that site than at the other four. Flake cortex frequencies at the other four sites are within the expected range.
Ideally, the collected debitage assemblage would have been sufficiently larger and varied by type so that a complete analysis of expected frequencies by flake type would demonstrate the same lithic reduction patterns as cortex amounts. However only three flake types were identified in the debitage assemblage, dominated by 68 platform/core preparation flakes, followed by four biface manufacturing flakes, and one sequence flake. The lack of other flake types is indicative of the limited range of lithic reduction activities carried out on the Northrup Park sites.

The predominance of platform/core preparation flakes (93.2 percent) at all five sites collectively is consistent with the predominance of flakes with cortex (84.9 percent) and suggests early- to middle-stage reduction activities were generally the most predominant activities across the Northrup Park sites.

Table 3. Standard Deviation Analysis for Debitage Cortex by Site

Top value $=$ observed count. Middle value $=$ relative frequency of flake cortex from all sites. Bottom value $=$ adjusted residual.

Significant values are shown in bold

\begin{tabular}{|c|c|c|c|c|}
\hline $\begin{array}{c}\text { Site } \\
(41 \mathrm{KE})\end{array}$ & Primary & Secondary & Tertiary & Total \\
\hline 141 & $\begin{array}{c}11 \\
15.1 \% \\
0.9\end{array}$ & $\begin{array}{c}7 \\
9.6 \% \\
-0.8\end{array}$ & $\begin{array}{c}3 \\
4.1 \% \\
-0.1\end{array}$ & 21 \\
\hline 142 & $\begin{array}{l}2 \\
2.7 \% \\
-1.0\end{array}$ & $\begin{array}{c}6 \\
8.2 \% \\
0.7\end{array}$ & $\begin{array}{c}2 \\
2.7 \% \\
0.4\end{array}$ & 10 \\
\hline 143 & $\begin{array}{c}6 \\
8.2 \% \\
-0.7\end{array}$ & $\begin{array}{c}8 \\
11.0 \% \\
-0.3\end{array}$ & $\begin{array}{c}6 \\
8.2 \% \\
1.7\end{array}$ & 20 \\
\hline 144 & $\begin{array}{c}4 \\
5.5 \% \\
0.5\end{array}$ & $\begin{array}{c}4 \\
5.5 \% \\
0.2\end{array}$ & $\begin{array}{c}0 \\
0.0 \% \\
-1.1\end{array}$ & 8 \\
\hline 145 & $\begin{array}{c}6 \\
8.2 \% \\
0.2\end{array}$ & $\begin{array}{c}8 \\
11.0 \% \\
0.7\end{array}$ & $\begin{array}{c}0 \\
0.0 \% \\
-1.5\end{array}$ & 14 \\
\hline $\begin{array}{c}\text { Column } \\
\text { Total }\end{array}$ & $\begin{array}{c}29 \\
39.7 \%\end{array}$ & $\begin{array}{c}33 \\
45.2 \%\end{array}$ & $\begin{array}{c}11 \\
15.1 \%\end{array}$ & $\begin{array}{c}73 \\
100.0 \%\end{array}$ \\
\hline
\end{tabular}


Further evaluation of the evidence of reduction activities is presented in Table 3. Bifaces, unifaces, and points which generally indicate middle to late stage reduction are combined and compared to core frequencies at each site. Fewer than expected middle and late stage pieces were found at $41 \mathrm{KE} 141$. This evaluation suggests that tools and bifaces were being produced less frequently at $41 \mathrm{KE} 141$. A significantly higher frequency of bifaces, unifaces, and points at $41 \mathrm{KE} 145$ suggests that it was primarily a middle or late stage reduction site.

To further examine reduction activities, the mean and standard deviation of flake length by site are presented in Figure 16. Table 4 shows that at $41 \mathrm{KE} 141$ there were fewer bifaces, unifaces, and points being manufactured, however Figure 16 shows that the mean flake length at $41 \mathrm{KE} 141$ is the shortest $(3.9 \mathrm{~cm})$ of the five sites sampled. The data from Table 4 suggests that more bifaces, unifaces, and points were produced at $41 \mathrm{KE} 145$, yet Figure 16 shows that the mean flake length $(5.71 \mathrm{~cm})$ at that site is the longest.

An argument can be made that flake size generally declines as a core or biface is reduced. If that argument is valid for the Northrup Park sites, then the flake length data (Figure 16) suggests that generally the tools being manufactured at $41 \mathrm{KE} 141$ were carried off (Table 4), leaving behind only relatively smaller debitage as evidence of tool manufacturing. However, platform preparation flakes are in general smaller than others, so the pattern may be deceiving unless the presence or absence of cortex is considered. At 41KE141, slightly more than half (52.4 percent ; 11 of 21 ) of the complete flakes contain cortex, suggesting they were chipped off during early stage reduction activities.

Although less than half (42.9 percent; 6 of 14) of the complete flakes at $41 \mathrm{KE} 145$ contained cortex indicative of early-stage reduction, this contradicts the relatively high quantity of tools observed at the site, suggesting that more middle- and late-stage reduction tools manufactured at $41 \mathrm{KE} 145$ were abandoned there.

If bifaces, unifaces, or points are being abandoned, it should be because they were broken in manufacture or use, or they were considered to be of too poor knappable quality for completion. Breakage and raw material data were recorded on bifaces from all sites. At $41 \mathrm{KE} 141$ and $41 \mathrm{KE} 143$, three of seven (43 percent) bifaces were broken or made of coarse-grained material. Of the six bifaces found at $41 \mathrm{KE} 145$, five (83 percent) were broken or made from coarse-grained material.

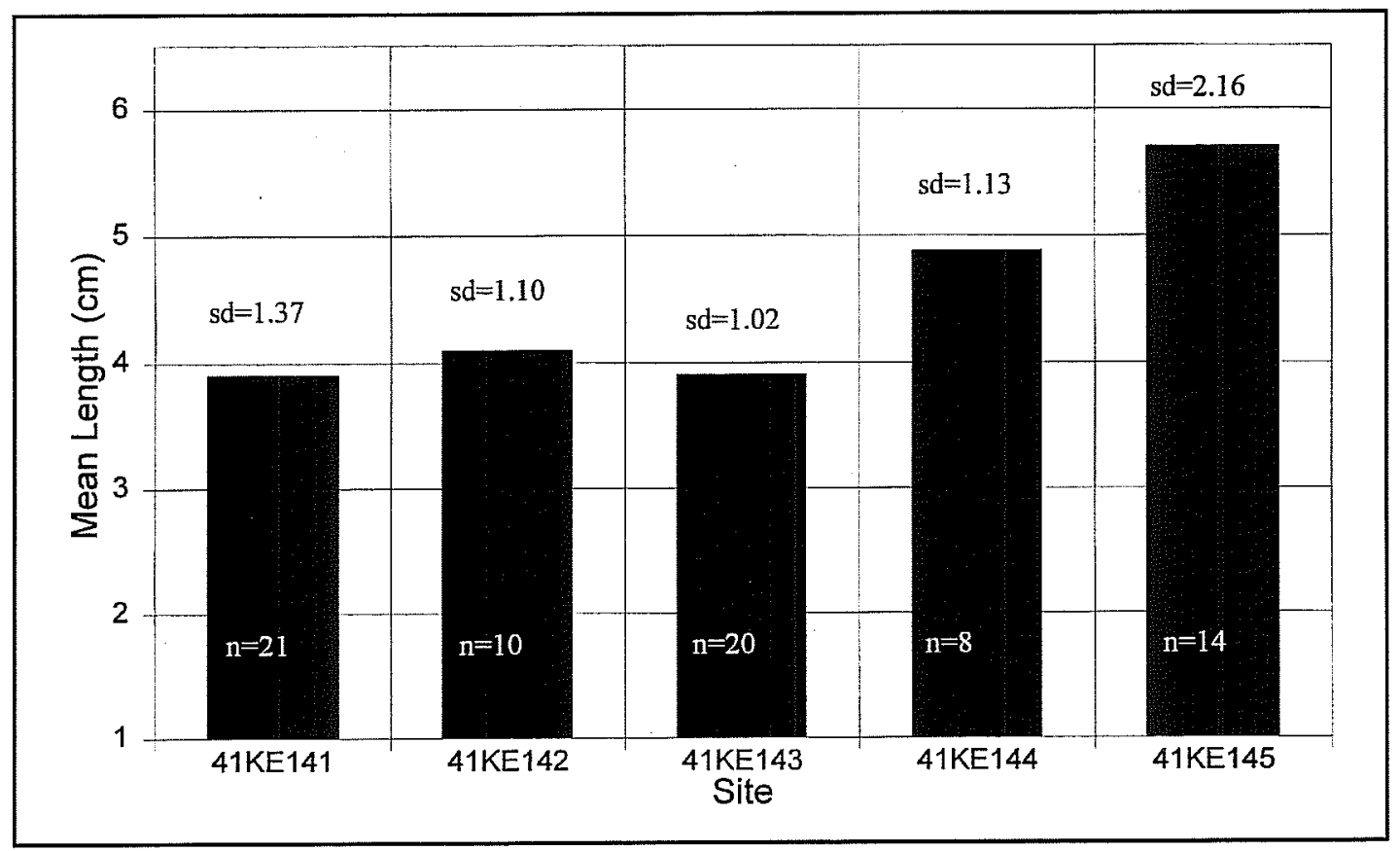

Figure 16. Mean flake length. 
Table 4. Standardized Deviation Analysis for Cores, Bifaces, Unifaces, and Points by Site

Top value $=$ observed count. Middle value $=$ relative frequency of cores and tools from all sites.

Bottom value $=$ adjusted residual

Significant values are shown in bold

\begin{tabular}{|c|c|c|c|}
\hline $\begin{array}{c}\text { Site } \\
(41 \mathrm{KE})\end{array}$ & Cores & $\begin{array}{c}\text { Bif, } \\
\text { Unif, Pts }\end{array}$ & Total \\
\hline 141 & $\begin{array}{c}40 \\
23.5 \% \\
0.7\end{array}$ & $\begin{array}{c}2 \\
1.2 \% \\
-1.7\end{array}$ & 42 \\
\hline 142 & $\begin{array}{c}10 \\
5.9 \% \\
-0.3\end{array}$ & $\begin{array}{c}3 \\
1.8 \% \\
0.8\end{array}$ & 13 \\
\hline 143 & $\begin{array}{c}56 \\
32.9 \% \\
0.4\end{array}$ & $\begin{array}{c}6 \\
3.5 \% \\
-1.0\end{array}$ & 62 \\
\hline 144 & $\begin{array}{c}20 \\
11.8 \% \\
0.1\end{array}$ & $\begin{array}{c}3 \\
1.8 \% \\
-0.2\end{array}$ & 23 \\
\hline 145 & $\begin{array}{c}19 \\
11.2 \% \\
-1.3\end{array}$ & $\begin{array}{c}11 \\
6.5 \% \\
\mathbf{3 . 1}\end{array}$ & 30 \\
\hline $\begin{array}{c}\text { Column } \\
\text { Total }\end{array}$ & $\begin{array}{c}145 \\
85.3 \%\end{array}$ & $\begin{array}{c}25 \\
14.7 \%\end{array}$ & $\begin{array}{c}170 \\
100.0 \%\end{array}$ \\
\hline
\end{tabular}

\section{Artifact Analysis Summary}

Although early-stage reduction activities occurred at all five sampled sites, at $41 \mathrm{KE} 141$ fewer bifaces, unifaces, and points were produced, suggesting more early-stage reduction occurred there than at the other sites. The presence of greater-than-expected frequencies of tertiary flakes at $41 \mathrm{KE} 143$ suggests that its occupants produced more finished or nearly finished tool or bifaces than did the occupants of the other four sites. A greater-than-expected frequency of bifaces, unifaces, and points at $41 \mathrm{KE} 145$ suggests that middleto late-stage reduction activities were more commonly practiced there than at the other four sites.

\section{Summary and Recommendations}

The pedestrian survey and shovel testing project at Northrup Park located seven prehistoric sites including one with a historic component. Six of the seven were later surface collected and one of those was further shovel tested. Three sites (41KE143, 41KE146, and $41 \mathrm{KE} 147$ ) were found to have potential for further investigation.

Based on diagnostic artifacts recovered from the surface of two sites the period of occupation ranges from the Transitional Archaic (ca. $1200-1400$ B.P.) to as early as the Early Archaic (ca. $6000-8800$ B.P.). Other surface artifacts recovered suggest that lithic reduction activities ranging from cores to formal tools occurred at least at six of the seven sites.

Among the many unknowns about the people who occupied the Northrup Park sites, including what they ate and their socioeconomic structure, is the source of raw material for making stone tools. The fact that a piece of obsidian from a source in New Mexico some 1,000 miles distant was found at Northrup Park suggests possible extended trade networks or movement, by people who valued quality raw material.

Archaeologists observed the apparent absence of quality chert raw materials in the Boerne area, both through studying geologic atlas sheets and by driving the roads in the surrounding area examining hillsides, stream channels, and cutbanks. This raises the issue of how good quality raw material got to the sites at Northrup Park. Raw materials should be gathered from the sites at Northrup Park and from nearby outcrops. An analysis of the raw material types and artifacts present on the Northrup Park sites and the raw materials available nearby should be conducted to identify the raw material source of the lithic artifacts at Northrup Park.

Seven archaeological sites were identified and recorded within the project boundary. Sites $41 \mathrm{KE} 141$, 41KE142, 41KE143, 41KE144, 41KE145, and $41 \mathrm{KE} 147$ will be impacted by construction related activities. Due to the inability to alter the proposed plans for the park, these six sites were 100-percent surface collected. No significant cultural material will be impacted by the proposed undertaking and it is rec- 
ommended that the six sites are ineligible for listing in the National Register of Historic Places. The only archaeological site not to be impacted by current construction plans is $41 \mathrm{KE} 146$. This site is minimally disturbed and has a high potential for contributing to our understanding of the Late Archaic in central Texas. Additional testing is recommended at $41 \mathrm{KE} 146$ prior to any planned development that would impact the site. 


\section{References Cited}

Avory, C.

1969 The 1902 Edition of the Sears, Roebuck Catalogue. Crown, New York.

Bass, F. A., Jr., and T. R. Hester

1975 An Archaeological Survey of the Upper Cibolo Creek Watershed, Central Texas. Archaeological Survey Report, No. 8. Center for Archaeological Research, The University of Texas at San Antonio.

Benfer, R., and A. Benfer

1965 An Austin Focus Burial. Texas Engineering and Science Magazine 1(1):74-79.

Binford, L. R.

1980 Willow Smoke and Dogs' Tails: Hunter-Gatherer Settlement Systems and Archaeological Site Formation. American Antiquity 45:4-20.

Black, S. L.

1986 The Clemente and Herminia Hinojosa Site, 41JW8: A Toyah Horizon Campsite in Southern Texas. Special Report, No. 18. Center for Archaeological Research, The University of Texas at San Antonio.

1989 a Environmental Setting. In From the Gulf Coast to the Rio Grande: Human Adaptation in the Central, South, and Lower Pecos Texas, edited by T. R. Hester, S. L. Black, D. G. Steele, B. W. Olive, A. A. Fox, K. J. Reinhard, and L. C. Bement, pp. 5-17. Research Series No. 33. Arkansas Archeological Survey, Fayetteville.

$1989 b$ Central Texas Plateau Prairie. In From the Gulf Coast to the Rio Grande: Human Adaptation in the Central, South, and Lower Pecos Texas, edited by T. R. Hester, S. L. Black, D. G. Steele, B. W. Olive, A. A. Fox, K. J. Reinhard, and L. C. Bement, pp. 17-38. Research Series No. 33. Arkansas Archeological Survey, Fayetteville.

Black, S. L., and A. J. McGraw

1985 The Panther Springs Creek Site: Cultural Change and Continuity in the Upper Salado Creek Drainage, South-Central Texas. Archaeological Survey Report, No. 100. Center for Archaeological Research, The University of Texas at San Antonio.

Black, S. L., L. W. Ellis, D. G. Creel, and G. T. Goode (editors)

1997 Hot Rock Cooking on the Greater Edwards Plateau: Four Burned Rock Midden Sites in West Central Texas. Studies in Archeology 22. Texas Archeological Research Laboratory, The University of Texas at Austin.

Black, S. L., K. Jolly, and D. R. Potter

1993 The Higgins Experiment: Field Report. Wurzbach Project Working Papers. Texas Archeological Research Laboratory, The University of Texas at Austin.

Bolton, H. E.

1970 [1915] Texas in the Middle Eighteenth Century: Studies in Spanish Colonial History and Administration. University of Texas Press, Austin. 
Boyd, D. K., I. W. Cox, and H. G. Uecker

1990 Archeological and Historical Investigations at Camp Bullis Bexar and Comal Counties, Texas: The 1989 Season. Prewitt and Associates, Austin.

Brown, K. M.

1987 Early Occupation at Berger Bluff, Goliad County, Texas. Current Research in the Pleistocene 4:3-5.

Brune, G.

1975 Major and Historic Springs of Texas. Report \#189. Texas Water Development Board, Austin.

Campbell, T. N.

1975 The Payaya Indians of Southern Texas. Special Publications No. 1. Southern Texas Archaeological Association, San Antonio.

1983 Coahuiltecans and Their Neighbors. In Handbook of North American Indians, Volume 10: Southwest, edited by A. Ortiz, pp. 343-358. Smithsonian Institution, Washington, D.C.

1991 Coahuiltecans and Their Neighbors. In Ethnology of Texas Indians, edited by T. R. Hester. Spanish Borderlands Sourcebooks 7. Garland, New York.

Campbell, T. N., and T. J. Campbell

1981 Historic Indians of the Choke Canyon Reservoir Surrounding Area, Southern Texas. Choke Canyon Series, No. 1. Center for Archaeological Research, The University of Texas at San Antonio.

1985 Indian Groups Associated with Spanish Missions of the San Antonio San Antonio Missions National Historical Park. Special Report, No. 16. Center for Archaeological Research, The University of Texas at San Antonio.

Chandler, C. K., and K. Hindes

1993 Scottsbluff Points from Atascosa, Frio, and McMullen Counties, South-Central Texas. La Tierra 20(1):31-36.

Chipman, D. E.

1992 Spanish Texas, 1519-1821. University of Texas Press, Austin.

Collins, M. B.

1995 Forty Years of Archaeology in Texas. Bulletin of the Texas Archeological Society 66:361-400.

Collins, M. B., C. B. Bousman, P. Goldberg, P. R. Takac, J. C. Guy, J. L. Lantana, T. W. Stafford, and V. T. Holliday.

1993 The Paleoindian Sequence at the Wilson-Leonard Site, Texas. Current Research in the Pleistocene 10:10-12.

Collins, M. B., B. Ellis, and C. Dodt-Ellis

1990 Excavations at the Camp Pearl Wheat Site (41KR243): An Early Archaic Campsite on Town Creek, Kerr County, Texas. Studies in Archeology 6. Texas Archeological Research Laboratory, The University of Texas at Austin.

Collins, M. B., G. L. Evans, T. N. Campbell, M. C. Winans, and C. E. Mears

1989 Clovis Occupation at Kincaid Rockshelter. Current Research in the Pleistocene 6:3-5. 
Creel, D. G.

1986 A Study of Prehistoric Burned Rock Middens in West Central Texas. Unpublished Ph.D. dissertation. The University of Arizona, Tucson.

de la Teja, J. F.

1995 San Antonio de Béxar: A Community of New Spain's Northern Frontier. University of New Mexico Press, Albuquerque.

Dial, S. W.

1992 Civilian Artifacts. In Archaeological Investigations in Alamo Plaza, San Antonio, Bexar County, Texas, 1988 and 1989. Archaeological Survey Report, No. 205. Center for Archaeological Research, The University of Texas at San Antonio.

Dibble, D. S., and D. Lorrain

1968 Bonfire Shelter: A Stratified Bison Kill Site, Val Verde County, Texas. Miscellaneous Papers 1. Texas Memorial Museum, Austin.

Dillehay, $\mathrm{T}$.

1974 Late Quaternary Bison Population Changes on the Southern Plains. Plains Anthropologist 19(64): 180-196.

Dittemore, W. H., and J. L. Hensell

1981 Soil Survey of Kendall County. U.S. Department of Agriculture, Soil Conservation Service. Washington, D.C.

Dobyns, H. F.

1966 Estimating Aboriginal American Population, an Appraisal of Techniques with a New Hemispheric Estimate. Current Anthropology 7:395-416.

Ewers, J. C., editor

1969 The Indians of Texas in 1830. Publication series 4745. Smithsonian Institution Press, Washington, D.C.

Fehrenbach, T. R.

1978 The San Antonio Story. Continental Heritage, Tulsa, Oklahoma.

1983 Lone Star: A History of Texas and the Texans. American Legacy, New York.

Flanagan, S.

1974 Trailing the Longhorns: A Century Later. Madrona, Austin.

Fox, A. A., I. W. Cox, L. Highley, and D. Hafernik

1989 Archaeological and Historical Investigations at the Site of the New Bexar County Justice Center in Downtown San Antonio, Texas. Archaeological Survey Report, No. 184. Center for Archaeological Research, The University of Texas at San Antonio. 
Freeman, M. D.

1994 Agriculture in Texas: Ranching and Stock Farming on the Eastern Edwards Plateau, 1845-1941. Komatsu/Rangel, Fort Worth.

Gerstle, A., T. C. Kelley, and C. Assad

1978 The Fort Sam Houston Project: An Archaeological and Historical Assessment. Archaeological Survey Report, No. 40. Center for Archaeological Research, The University of Texas at San Antonio.

Givens, R. D.

1968 A Preliminary Report on Excavations at Hitzfelder Cave. Bulletin of the Texas Archeological Society 38:47-50.

Goode, G. T.

1991 Late Prehistoric Burned Rock Middens in Central Texas. In The Burned Rock Middens of Texas: An Archeological Symposium, edited by T. R. Hester, pp. 71-93. Studies in Archeology 13, Texas Archeological Research Laboratory, The University of Texas at Austin.

Greer, G. H.

1981 American Stonewares, The Art and Craft of Utilitarian Potters. Schiffer, Exton, Pennsylvania.

Guderjan, T. H.

1991 At the Escarpment's Edge: An Initial Report on Excavations at Cueva Corbin. La Tierra 18(4):4-9.

Guderjan, T. H., B. Baker, B. Bousman, C. K. Chandler, A. Fox, and B. Meissner

1992 Prehistoric Settlement in the Medina Valley and the 1991 STAA-ITC Field School. La Tierra 19(2): 14-28.

Guderjan, T. H., B. Meissner, B. Baker, C. K. Chandler, S. Kennedy, D. McReynolds, H. R. Smith, F. Ward, J. Watts, and J. Zapata

1993 The Medina Valley Project and the 1992 STAA-ITC Field School. La Tierra 20(1):12-26.

Haberman, S. J.

1978 Analysis of Qualitative Data. Academic, New York.

Habig, M. A.

1968a The Alamo Chain of Missions, A History of San Antonio's Five Old Missions. Franciscan Herald, Chicago.

1968b San Antonio's Mission San José, State and National Historic Site, 1720-1968. Naylor, San Antonio.

Hard, R. J., A. A. Fox, I. W. Cox, K. J. Gross, B. A. Meissner, G. Mendez, C. L. Tennis, and J. Zapata 1995 Excavations at Mission San Jose y Miguel de Aguayo, San Antonio, Texas. Archaeological Survey Report, No. 218. Center for Archaeological Research, The University of Texas at San Antonio.

Hall, G. D.

1981 Allens Creek: A Study in the Cultural Prehistory of the Brazos River Valley, Texas. Research Report 61. Texas Archeological Survey, The University of Texas at Austin. 
Harris, E. S.

1985 An Archaeological Study of the Timmeron Rockshelter (41HY95), Hays County, South Central Texas. Special Publication 4. Southern Texas Archaeological Association, San Antonio.

Henderson, J.

1978 Faunal Analysis of Site 41BX36, with Data Presented for 41BX377 and 41BX428. In The Fort Sam Houston Project: An Archaeological and Historical Assessment, edited by A. Gerstle, T. C. Kelly, and C. Assad, pp. 229-252. Archaeological Survey Report, No. 40. Center for Archaeological Research, The University of Texas at San Antonio.

Hester, T. R.

1968a Paleo-Indian Artifacts Along San Miguel Creek: Frio, Atascosa, and McMullen Counties, Texas. Bulletin of the Texas Archeological Society 39:147-162.

1968b Folsom Points from Southwest Texas. Plains Anthropologist 15(50):237-250.

1970 Burned Rock Midden Sites on the Southwestern Edge of the Edwards Plateau, Texas. Plains Anthropologist 15:237-248.

1971 Archeological Investigations at the La Jita Site, Uvalde County, Texas. Bulletin of the Texas Archeological Society 42:51-148.

1983 Late Paleo-Indian Occupations at Baker Cave, Southwestern Texas. Bulletin of the Texas Archeological Society 53:101-119

1988 Paleoindian Obsidian Artifacts from Texas: A Review. Current Research in the Pleistocene 5:27.

1989 Historic Native American Populations. In From the Gulf to the Rio Grande: Human Adaptation in Central, South, and Lower Pecos Texas, edited by T. R. Hester, S. L. Black, D. G. Steele, B. W. Olive, A. A. Fox, K. J. Reinhard, and L. C. Bement, pp. 1-4. Arkansas Archeological Survey Research Series 33. Arkansas Archeological Survey, Fayetteville.

1995 The Prehistory of South Texas. Bulletin of the Texas Archeological Society 66:427-459.

Hester, T. R., G. L. Evans, F. Asaro, F. Stross, T. N. Campbell, and J. Michel

1985 Trace Element Analysis of an Obsidian Paleo-Indian Projectile Point from Kincaid Rockshelter, Texas. Bulletin of the Texas Archeological Society 56:143-153.

Howard, C. D.

1974 Paleo-Indian Surface finds in Bexar County. La Tierra 1(4):14-17.

Houk, B. A., and D. L. Nickels

1997 Phase II Archaeological Investigations at Lackland Air Force Base, San Antonio, Texas. Archaeological Survey Report, No. 264. Center for Archaeological Research, The University of Texas at San Antonio.

Huebner, J. A.

1991 Late Prehistoric Bison Populations in Central and Southern Texas. Plains Anthropologist 36(137): 343-358.

Hulbert, R. C., Jr.

1985 Vertebrate Faunal Remains. In The Panther Springs Creek Site: Cultural Change and Continuity within the Upper Salado Creek Watershed, South-Central Texas, by S. L. Black and A. J. McGraw, pp. 209-215. Archaeological Survey Report, No. 100. Center for Archaeological Research, The University of Texas at San Antonio. 
Illinois Glass Company

1904 Illustrated Catalogue and Price List. Alton, Illinois.

Inglis, J. M.

1964 A History of Vegetation on the Rio Grande Plain. Bulletin \#45. Texas Parks and Wildlife Department, Austin.

Jackson, J.

1986 Los Mesteños. Texas A\&M University Press, College Station.

Jelinek, A., B. Bradley, and B. Huckell

1971 The Production of Secondary Multiple Flakes. American Antiquity 36:198-200.

John, E. A. H.

1975 Storms Brewed in Other Men's Worlds: The Confrontation of Indians, Spanish, and French in the Southwest, 1540-1795. Texas A\&M University Press, College Station.

Johnson, L., Jr.

1987 A Plague of Phases. Bulletin of the Texas Archeological Society 57:1-26.

1994 The Reconstructed Crow Terminology of the Titkanwatits, or Tonkawas, with Inferred Social Correlates. Plains Anthropologist (39) 150:377-413.

Johnson, L., and T. N. Campbell

1992 Sanan: Traces of a Previously Unknown Aboriginal Language in Colonial Coahuila and Texas. Plains Anthropologist 37(140):185-212.

Johnson, L., and G. T. Goode

1994 A New Try at Dating and Characterizing Holocene Climates, as well as Archaeological Periods, on the Eastern Edwards Plateau. Bulletin of the Texas Archeological Society 65:1-51.

Jones, O. L., Jr.

1979 Los Paisanos-Spanish Settlers on the Northern Frontier of New Spain. University of Oklahoma Press, Norman.

Kelley, D.

1971 Indian Tribes of Texas, edited by D. H. Winfrey. Texian, Waco.

Kelly, T. C.

1993 Preceramic Projectile-Point Typology in Belize. Ancient Mesoamerica 4:205-227.

Kelly, T. C., and T. R. Hester

1976a Archaeological Investigations at Sites in the Upper Cibolo Creek Watershed, Central Texas. Archaeological Survey Report, No. 17. Center for Archaeological Research, The University of Texas at San Antonio

1976b An Archaeological Assessment of Boerne City Park, Kendall County, Texas. Archaeological Survey Report, No. 21. Center for Archaeological Research, The University of Texas at San Antonio. 
Krakker, J. J., M. J. Shott, and P. D. Welch

1983 Design and Evaluation of Shovel-Test Sampling in Regional Archaeological Survey. Journal of Field Archaeology 10:469-480.

Lehmann, V. W.

1969 Forgotten Legions. Texas Western, The University of Texas at El Paso.

León, A., J. B. Chapa, and F. S. de Zamora

1961 Historia de Luevo León, con Noticias sobre Cohuila, Tamaulipas, Texas y Nueva México. Estudio Preliminar y Notas de Israel Cavzos Garza. Centrio de Estudios Humanistico. Universidad de Nuevo León, Monterrey.

Logan, O. C. 1959 Cartridges: A Pictorial Digest of Small Arms Ammunition. Bonanza Books, New York.

Lukowski, P. D.

1988 Archaeological Investigations at 41BXI, Bexar County, Texas. Archaeological Survey Report, No. 135. Center for Archaeological Research, The University of Texas at San Antonio.

Lynch, B. M.

1980 Site Artifact Density and the Effectiveness of Shovel Probes. Current Anthropology 21:516-517.

McGraw, A. J.

1985 An Overview of the Prehistory of the Upper Salado Creek Watershed. In The Panther Springs Creek Site: Cultural Change and Continuity within the Upper Salado Creek Watershed, South-Central Texas, edited by S. L. Black and A. J. McGraw, pp. 302-326. Archaeological Survey Report, No. 100. Center for Archaeological Research, The University of Texas at San Antonio.

McGraw, A. J., and K. Hindes

1987 Chipped Stone and Adobe: A Cultural Resources Assessment of the Proposed Applewhite Reservoir, Bexar County, Texas. Archaeological Survey Report, No. 163. Center for Archaeological Research, The University of Texas at San Antonio.

McGraw, A. J., and F. Valdez, Jr.

1978 Investigations of Prehistoric Rockshelter and Terrace Sites Along Portions of the Salado Creek Drainage, Northern Bexar County, Texas. Archaeological Survey Report, No. 55. Center for Archaeological Research, The University of Texas at San Antonio.

McGraw, A. J., F. Valdez, Jr., and I. W. Cox

1977 Archaeological Survey of Areas Proposed for Modification in the Encino Park Development, Northern Bexar County, Texas. Archaeological Survey Report, No. 39. Center for Archaeological Research, The University of Texas at San Antonio.

McKinney, W.

1981 Early Holocene Adaptation in Central and Southern Texas: The Problem of the Paleo-Indian-Archaic Transition. Bulletin of the Texas Archeological Society 52:91-120. 
McManamon, F. P.

1984 Discovering Sites Unseen. In Advances in Archaeological Method and Theory, edited by M. B. Schiffer, 7:223-292. Academic, Orlando.

Meissner, B. A.

1991 Notes on the Excavation of 41BX952. Manuscript on file. Center for Archaeological Research, The University of Texas at San Antonio.

1993 Where the Buffalo Roam: Archaeological Evidence of Bison Populations in South and Central Texas. Manuscript on file. Center for Archaeological Research, The University of Texas at San Antonio.

Mehalchick, G., K. Kleinbach, D. K. Boyd, S. A. Tomka, and K. W. Kibler

1996 National Register Testing of 19 Prehistoric Archeological Sites on Fort Hood, Texas: The 1995 Season. United States Army Fort Hood Archeological Resource Management Series, Research Report No. 37. Prewitt and Associates, Austin.

Meltzer, D. J., and M. R. Bever

1995 Paleoindians of Texas: An Update on the Texas Clovis Fluted Point Survey. Bulletin of the Texas Archeological Society 66:47-81.

Miller, G. L., and A. Pacey

1985 Impact of Mechanization in the Glass Container Industry: The Dominion Glass Company of Montreal, A Case Study. Historical Archaeology 19(1):38-50.

Munsey, C.

1970 The Illustrated Guide to Collecting Bottles. Bounty Books, New York.

Newcomb, W. W., Jr.

1961 The Indians of Texas: From Prehistoric to Modern Times. University of Texas Press, Austin.

1993 The Indians of Texas: From Prehistoric to Modern Times. The University of Texas at Austin.

Nickels, D. L., C. B. Bousman, J. D. Leach, and D. A. Cargill

1998 Test Excavations at the Culebra Creek Site, 41BX126, San Antonio, Texas. Archaeological Survey Report, No. 265. Center for Archaeological Research, The University of Texas at San Antonio. Archeological Studies Program, No. 3. Texas Department of Transportation, Austin.

Nickels, D. L., J. D. Leach, S. K. Tomka, and B. D. Moses

1997a The Moos Site (41BX1232): A Late Paleoindian Component Site in South Central Texas. Current Research in the Pleistocene 14:68-69.

Nickels, D. L., D. W. Pease, and C. B. Bousman

1997b Archaeological Survey of Lackland Air Force Base, Bexar County, Texas. Archaeological Survey Report, No. 248. Center for Archaeological Research, The University of Texas at San Antonio.

Norusis, M. J.

1993 SPSS 6.1: Guide to Data Analysis. Prentice Hall, Englewood Cliffs, New Jersey. 
Patterson, L. W.

1988 Intergroup Conflict in Prehistoric Texas. Houston Archeological Society Journal 90:8-10.

Patterson, L. W., and J. H. Adams

1977 An Archaeological Complex in Kendall County. La Tierra 4(2):6-16.

Peter, D. E., T. R. Hays, and M. Demuynck

1982a An Evaluation of the "Phase" Concept. In Archaeological Investigations at the San Gabriel Reservoir Districts, Central Texas, Volume 2, edited by T. R. Hays, pp. 21-1-21-17. Archaeology Program, Institute of Applied Sciences, North Texas State University, Denton.

Peter, D. E., D. Prikyl, O. McCormick, and M. A. Demuynck

1982b Sites Excavation Reports: Primary Contract. In Archaeological Investigations at the San Gabriel Reservoir Districts, Central Texas, Volume 1, edited by T. R. Hays, pp. 8-1-8-156. Archaeology Program, Institute of Applied Sciences, North Texas State University, Denton.

Potter, D. R., C. K. Chandler, and E. Newcomb

1992 Archaeological Salvage Research at 41BX901, a Prehistoric Quarry in Bexar County, Texas. Archaeological Survey Report, No. 211. Center for Archaeological Research, The University of Texas at San Antonio.

Poyo, G. E., and G. M. Hinojosa (editors)

1991 Tejano Origins in Eighteenth-Century San Antonio. University of Texas Press, Austin.

Prewitt, E. R.

1974 Archeological Investigations at the Loeve-Fox Site, Williams County, Texas. Research Report 49. Texas Archeological Survey, The University of Texas at Austin.

1981 Cultural Chronology in Central Texas. Bulletin of the Texas Archeological Society 52:65-89.

1991 Burned Rock Middens: A Summary of Previous Investigations and Interpretations. In The Burned Rock Middens of Texas: An Archeological Symposium, edited by T. R. Hester, pp. 25-32. Studies in Archeology 13, Texas Archeological Research Laboratory, The University of Texas at Austin.

1985 From Circleville to Toyah: Comments on Central Texas Chronology. Bulletin of the Texas Archeological Society 54:201-238.

1995 Distribution of Typed Projectile Points in Texas. Bulletin of the Texas Archeological Society 66: 83-173.

Quigg, J. M.

1988 Cultural Resources Reconnaissance in Secondary Impact Areas Along Salado Creek at Brooke Army Medical Center, Fort Sam Houston and Camp Bullis, Bexar County, Texas. Technical Reports No. 5. Prewitt and Associates, Austin.

Rector, R. R.

1993 Live Oak Acorn Yield Studies in Relation to Hunter and Gathering Populations in Central Texas. Master's thesis on file. Center for Archaeological Research, The University of Texas at San Antonio.

Shafer, H. J.

1977 Art and Territoriality in the Lower Pecos Region, Texas. Plains Anthropologist 22:13-22. 
Simpson, B. J.

1988 A Field Guide to Texas Trees. Gulf, Houston.

Sjoberg, A. F.

1953a The Culture of the Tonkawa, A Texas Indian Tribe. Texas Journal of Science 5(3):280-304.

1953b Lipan Apache Culture in Historical Perspective. Southwestern Journal of Anthropology 9(1):76-98.

Skelton, D. W.

1977 Archaeological Investigations at the Fayetteville Power Project, Fayette County, Texas. Texas Archeological Survey Research Report No. 60. The University of Texas at Austin.

Skinner, S. A.

1981 Aboriginal Demographic Changes in Central Texas. Plains Anthropologist 26(92):111-118.

Sollberger, J., and T. R. Hester

1972 The Strohacker Site: A Review of Pre-Archaic Manifestations in Texas. Plains Anthropologist 17(58):326-344.

Steele, D. G., and C. Assad Hunter

1986 Analysis of Vertebrate Faunal Remains from 41MC222 and 41MC296, McMullen County, Texas. In The Prehistoric Sites at Choke Canyon Reservoir, Southern Texas: Results of Phase II Archaeological Investigations, edited by G. D. Hall, T. R. Hester, and S. L. Black. Choke Canyon Series, No. 10. Center for Archaeological Research, The University of Texas at San Antonio.

Story, D. A.

1985 Adaptive Strategies of Archaic Cultures of the West Gulf Coastal Plain. In Prehistoric Food Production in North America, edited by R. I. Ford, pp. 19-56. Anthropological Papers No. 75. Museum of Anthropology, The University of Michigan, Ann Arbor.

Swanton, J. R.

1952 The Indian Tribes of North America. Bulletin 145. Bureau of American Ethnology, Washington, D.C.

Taylor, A. J., and C. L. Highly

1995 Archaeological Investigations at the Loma Sandia Site (41LK28): A Prehistoric Campsite in Live Oak County, Texas. 2 volumes. Studies in Archeology No. 20. Texas Archeological Research Laboratory, The University of Texas at Austin.

Tennis, C. L., and R. J. Hard

1995 Archaeological Survey of the Upper Leon Creek Terraces, Bexar County, Texas. Archaeological Survey Report, No. 233. Center for Archaeological Research, The University of Texas at San Antonio.

Thomas, D. H.

1986 Refiguring Anthropology. Waveland, Prospect Heights, Illinois.

Toulouse, J. H.

1971 Bottle Makers and Their Marks. Thomas Nelson, New York. 
Turner, S. E., and T. R. Hester

1993 A Field Guide to Stone Artifacts of Texas Indians. Gulf, Houston.

Watson, R.

1965 Bitters Bottles. Thomas Nelson and Sons, New York.

Weir, F.

1976 The Central Texas Archaic. Ph.D. dissertation. Department of Anthropology, Washington State University, Pullman.

Wenke, R. J.

1990 Patterns in Prehistory: Humankind's First Three Million Years. 3rd edition. Oxford University Press, Oxford, England.

West, E. H. (translator)

1904 A Brief Compendium of the Events which Have Occurred in the Province of Texas from its Conquest, or Reduction to the Present Day, Written by Antonio Bonilla in 1772. Quarterly of the Texas State Historical Association VIII(1):1-78.

Winchester-Western Ammunition Handbook

1964 The Winchester-Western Ammunition Handbook. Pocket Books, New York.

Witkind, W. M.

1977 An Experiment in Stone Boiling. In Hop Hill: Culture and Climatic Change in Central Texas, edited by J. Gunn and R. Mahula, pp. 205-208. Special Report, No. 5. Center for Archaeological Research, The University of Texas at San Antonio.

Wobst, H. M.

1983 We Can't See the Forest for the Trees: Sampling and the Shapes of Archaeological Distributions. In Archaeological Hammers and Theories, edited by J. A. Moore and A. S. Keene, pp. 37-85. Academic, New York. 
Appendix A: Chipped Stone Artifact Attributes 

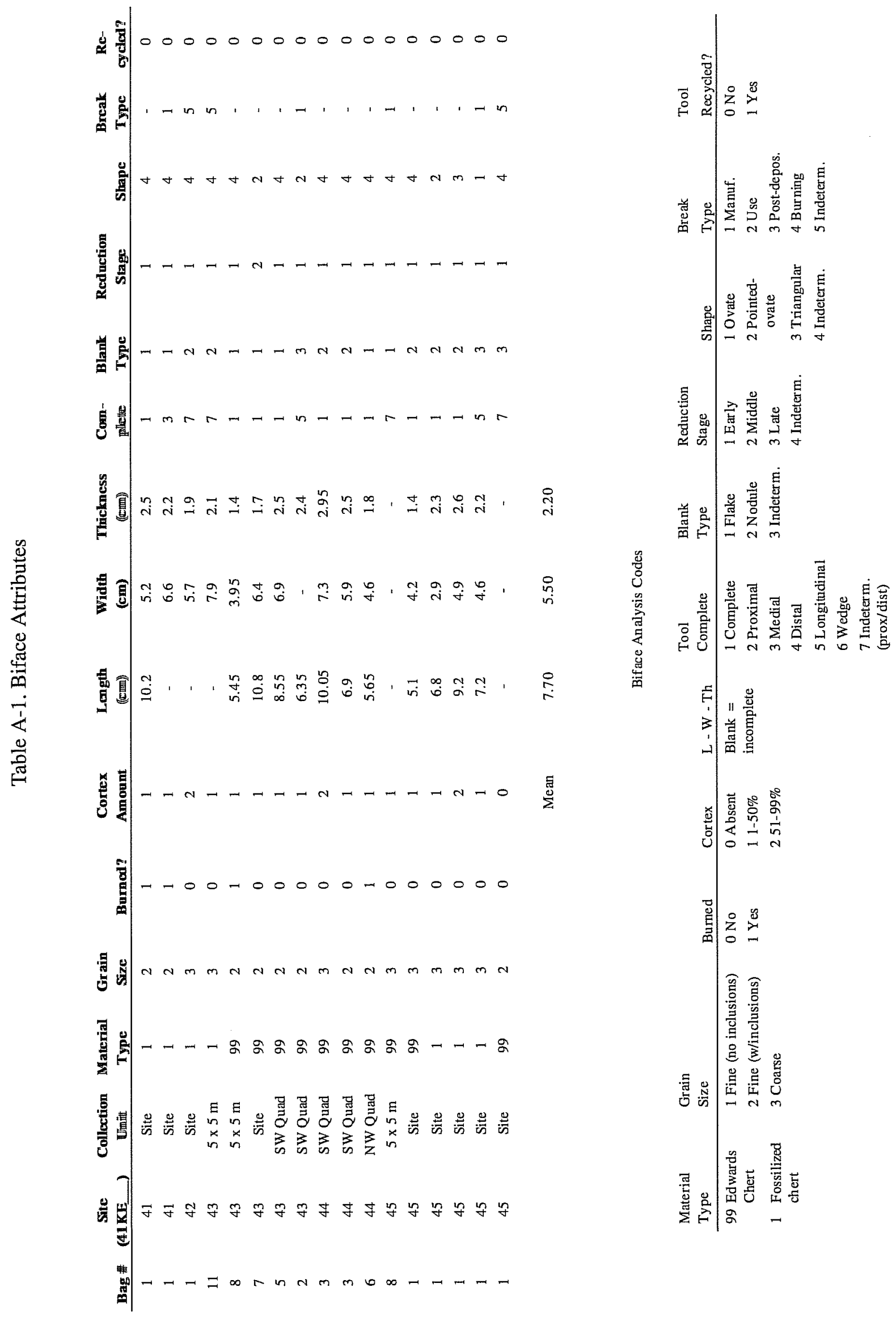

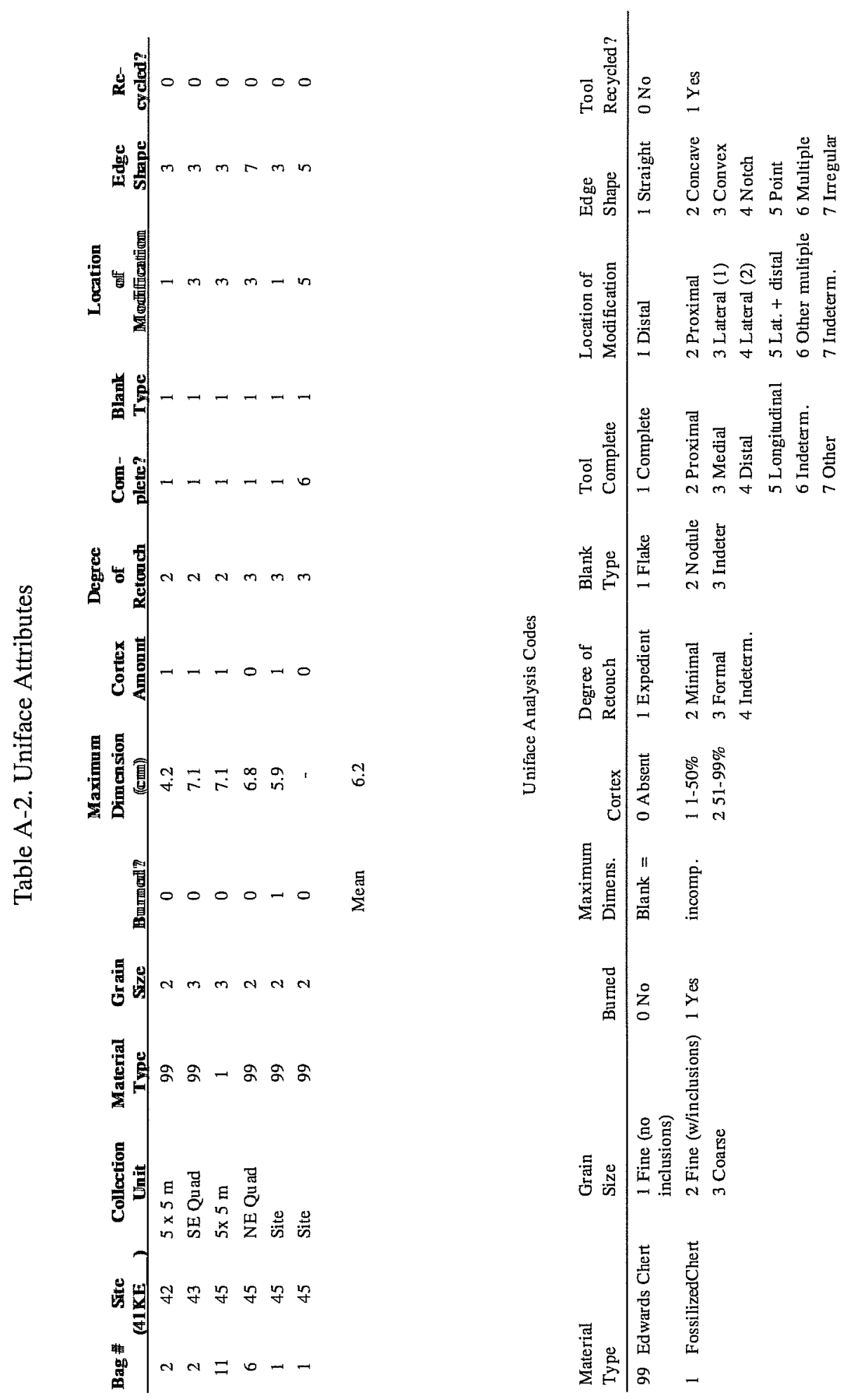
Table A-3. Core Attributes

\begin{tabular}{|c|c|c|c|c|c|c|c|c|c|}
\hline Bag \# & $\begin{array}{c}\text { Site } \\
\left(41 \mathrm{KE} \_\right.\end{array}$ & $\begin{array}{c}\text { Collection } \\
\text { Unit } \\
\end{array}$ & $\begin{array}{c}\text { Material } \\
\text { Type }\end{array}$ & $\begin{array}{c}\text { Grain } \\
\text { Size } \\
\end{array}$ & Burned? & $\begin{array}{l}\text { Maximum } \\
\text { Dimension }\end{array}$ & $\begin{array}{c}\text { Cortex } \\
\text { Amount } \\
\end{array}$ & $\begin{array}{c}\# \\
\text { Scars } \\
\end{array}$ & $\begin{array}{c}\text { Flake } \\
\text { Direction } \\
\end{array}$ \\
\hline 3 & 41 & $5 \times 5 \mathrm{~m}$ & 7 & 3 & 0 & 17 & 1 & 3 & 1 \\
\hline 3 & 41 & $5 \times 5 \mathrm{~m}$ & 30 & 3 & 0 & 13 & 2 & 1 & 1 \\
\hline 3 & 41 & $5 \times 5 \mathrm{~m}$ & 1 & 2 & 0 & 10 & 1 & 3 & 2 \\
\hline 1 & 41 & Site & 1 & 2 & 1 & 16 & 1 & 1 & 1 \\
\hline 1 & 41 & Site & 7 & 3 & 0 & 13 & 1 & 5 & 1 \\
\hline 1 & 41 & Site & 17 & 3 & 1 & 11 & 1 & 2 & 1 \\
\hline 1 & 41 & Site & 99 & 3 & 1 & 8 & 1 & 1 & 1 \\
\hline 1 & 41 & Site & 29 & 1 & 1 & 8 & 1 & 3 & 2 \\
\hline 1 & 41 & Site & 1 & 2 & 1 & 8 & 1 & 1 & 1 \\
\hline 1 & 41 & Site & 1 & 2 & 1 & 12 & 1 & 2 & 2 \\
\hline 1 & 41 & Site & 1 & 2 & 1 & 12 & 1 & 3 & 2 \\
\hline 1 & 41 & Site & 1 & 2 & 1 & 9 & 1 & 3 & 2 \\
\hline 1 & 41 & Site & 1 & 2 & 1 & 8 & 1 & 4 & 2 \\
\hline 1 & 41 & Site & 63 & 3 & 1 & 12 & 2 & 5 & 3 \\
\hline 1 & 41 & Site & 7 & 3 & 1 & 10 & 2 & 6 & 3 \\
\hline 1 & 41 & Site & 7 & 3 & 1 & 14 & 1 & 3 & 2 \\
\hline 1 & 41 & Site & 29 & 3 & 1 & 9 & 1 & 3 & 2 \\
\hline 1 & 41 & Site & 30 & 3 & 1 & 5 & 1 & 2 & 2 \\
\hline 1 & 41 & Site & 99 & 3 & 1 & 11 & 1 & 4 & 1 \\
\hline 1 & 41 & Site & 30 & 2 & 1 & 9 & 2 & 2 & 2 \\
\hline 2 & 41 & $5 \times 5 \mathrm{~m}$ & 25 & 3 & 0 & 7 & 1 & 1 & 1 \\
\hline 2 & 41 & $5 \times 5 \mathrm{~m}$ & 7 & 3 & 1 & 6 & 1 & 1 & 1 \\
\hline 2 & 41 & $5 \times 5 \mathrm{~m}$ & 99 & 3 & 1 & 5 & 1 & 3 & 3 \\
\hline 1 & 42 & Site & 1 & 3 & 0 & 9 & 2 & 3 & 1 \\
\hline 1 & 42 & Site & 1 & 3 & 1 & 8 & 2 & 4 & 3 \\
\hline 1 & 42 & Site & 99 & 3 & 1 & 6 & 1 & 6 & 3 \\
\hline 2 & 42 & $5 \times 5 \mathrm{~m}$ & 99 & 3 & 1 & 10 & 2 & 9 & 3 \\
\hline 2 & 42 & $5 \times 5 \mathrm{~m}$ & 29 & 3 & 0 & 8 & 1 & 4 & 2 \\
\hline 2 & 42 & $5 \times 5 \mathrm{~m}$ & 29 & 3 & 1 & 10 & 1 & 2 & 1 \\
\hline 2 & 42 & $5 \times 5 \mathrm{~m}$ & 45 & 3 & 1 & 10 & 1 & 1 & 1 \\
\hline 2 & 42 & $5 \times 5 \mathrm{~m}$ & 25 & 3 & 0 & 7 & 1 & 1 & 1 \\
\hline 2 & 42 & $5 \times 5 \mathrm{~m}$ & 7 & 3 & 1 & 6 & 1 & 1 & 1 \\
\hline 2 & 42 & $5 \times 5 \mathrm{~m}$ & 99 & 3 & 1 & 5 & 1 & 3 & 3 \\
\hline 12 & 43 & Site & 3 & 2 & 1 & 7 & 1 & 2 & 2 \\
\hline 4 & 43 & Site & 99 & 2 & 1 & 6 & 2 & 5 & 3 \\
\hline 4 & 43 & Site & 29 & 3 & 1 & 8 & 2 & 2 & 2 \\
\hline 4 & 43 & Site & 22 & 3 & 0 & - & 1 & - & 4 \\
\hline 4 & 43 & Site & 17 & 3 & 1 & - & 2 & - & 4 \\
\hline 4 & 43 & Site & 57 & 2 & 1 & 12 & 2 & 2 & 2 \\
\hline 4 & 43 & Site & 22 & 3 & 0 & - & 1 & - & 4 \\
\hline 4 & 43 & Site & 27 & 2 & 1 & - & 2 & - & 4 \\
\hline 4 & 43 & Site & 1 & 2 & 1 & 9 & 2 & 6 & 3 \\
\hline 4 & 43 & Site & 99 & 1 & 1 & - & 2 & - & 4 \\
\hline 11 & 43 & $5 \times 5 \mathrm{~m}$ & 1 & 3 & 0 & 10 & 2 & 9 & 3 \\
\hline 2 & 43 & Site & 99 & 3 & 1 & 10 & 2 & 6 & 3 \\
\hline 2 & 43 & Site & 99 & 3 & 0 & 5 & 2 & 4 & 3 \\
\hline 5 & 43 & SW Quad & 17 & 3 & 0 & 6 & 2 & 1 & 1 \\
\hline 2 & 43 & SE Quad & 99 & 3 & 0 & 20 & 2 & 13 & 3 \\
\hline
\end{tabular}


Table A-3. continued

\begin{tabular}{|c|c|c|c|c|c|c|c|c|c|}
\hline Bag \# & $\begin{array}{c}\text { Site } \\
(41 \mathrm{KE} \\
\end{array}$ & $\begin{array}{c}\text { Collection } \\
\text { Unit } \\
\end{array}$ & $\begin{array}{c}\text { Material } \\
\text { Type }\end{array}$ & $\begin{array}{c}\text { Grain } \\
\text { Size } \\
\end{array}$ & Burned? & $\begin{array}{l}\text { Maximum } \\
\text { Dimension } \\
\end{array}$ & $\begin{array}{c}\text { Cortex } \\
\text { Amount } \\
\end{array}$ & $\begin{array}{c}\# \\
\text { Scars } \\
\end{array}$ & $\begin{array}{c}\text { Flake } \\
\text { Direction }\end{array}$ \\
\hline 2 & 43 & SE Quad & 99 & 3 & 0 & 17 & 2 & 1 & 1 \\
\hline 2 & 43 & SE Quad & 99 & 3 & 1 & 12 & 2 & 1 & 1 \\
\hline 2 & 43 & SE Quad & 99 & 3 & 1 & 9 & 1 & 2 & 1 \\
\hline 3 & 43 & NE Quad & 99 & 2 & 0 & 18 & 2 & 13 & 3 \\
\hline 3 & 43 & NE Quad & 1 & 3 & 1 & 15 & 2 & 2 & 1 \\
\hline 3 & 44 & SW Quad & 27 & 3 & 1 & 10 & 1 & 5 & 2 \\
\hline 3 & 44 & SW Quad & 27 & 3 & 1 & 9 & 1 & 1 & 1 \\
\hline 3 & 44 & SW Quad & 63 & 3 & 1 & 9 & 2 & 1 & 1 \\
\hline 3 & 44 & SW Quad & 63 & 3 & 1 & 16 & 1 & 2 & 2 \\
\hline 4 & 44 & $5 \times 5 \mathrm{~m}$ & 17 & 3 & 1 & 11 & 2 & 1 & 1 \\
\hline 4 & 44 & $5 \times 5 \mathrm{~m}$ & 99 & 2 & 1 & - & 2 & 2 & 1 \\
\hline 4 & 44 & $5 \times 5 \mathrm{~m}$ & 1 & 3 & 1 & 14 & 2 & 3 & 2 \\
\hline 4 & 44 & $5 \times 5 \mathrm{~m}$ & 1 & 3 & 0 & 11 & 2 & 6 & 3 \\
\hline 2 & 44 & SE Quad & 1 & 3 & 0 & 13 & 2 & 4 & 2 \\
\hline 2 & 44 & SE Quad & 99 & 3 & 1 & 9 & 1 & 2 & 1 \\
\hline 2 & 44 & SE Quad & 17 & 3 & 0 & 18 & 2 & 1 & 1 \\
\hline 2 & 44 & SE Quad & 1 & 3 & 1 & 9 & 2 & 1 & 1 \\
\hline 2 & 44 & SE Quad & 63 & 3 & 1 & 16 & 2 & 1 & 1 \\
\hline 2 & 44 & SE Quad & 63 & 3 & 1 & 12 & 2 & 3 & 2 \\
\hline 6 & 44 & NW & 1 & 3 & 1 & 16 & 2 & 2 & 1 \\
\hline 6 & 44 & NW & 1 & 3 & 0 & 13 & 2 & 5 & 2 \\
\hline 6 & 44 & NW & 99 & 3 & 0 & - & 2 & 2 & 2 \\
\hline 6 & 44 & NW & 63 & 3 & 0 & 11 & 2 & 1 & 1 \\
\hline 6 & 44 & NW & 1 & 3 & 1 & 9 & 1 & 9 & 3 \\
\hline 5 & 44 & NE & 99 & 3 & 0 & 18 & 2 & 1 & 1 \\
\hline 7 & 45 & NW & 99 & 3 & 0 & 11 & 2 & 6 & 1 \\
\hline 7 & 45 & NW & 1 & 3 & 0 & 10 & 2 & 2 & 1 \\
\hline 7 & 45 & NW & 99 & 3 & 1 & 11 & 1 & 5 & 2 \\
\hline 10 & 45 & SE & 17 & 3 & 1 & 11 & 2 & 2 & 1 \\
\hline 9 & 45 & $5 \times 5 \mathrm{~m}$ & 17 & 3 & 1 & 12 & 2 & 6 & 2 \\
\hline 9 & 45 & $5 \times 5 \mathrm{~m}$ & 7 & 3 & 0 & 8 & 2 & 2 & 2 \\
\hline 9 & 45 & $5 \times 5 \mathrm{~m}$ & 7 & 3 & 0 & 6 & 1 & 2 & 2 \\
\hline 9 & 45 & $5 \times 5 \mathrm{~m}$ & 7 & 3 & 1 & 10 & 1 & 6 & 3 \\
\hline \multirow[t]{2}{*}{6} & 45 & NE Quad & 63 & 3 & 1 & 11 & 1 & 2 & 1 \\
\hline & & & & & Mean & 10.26 & & 3.18 & \\
\hline
\end{tabular}

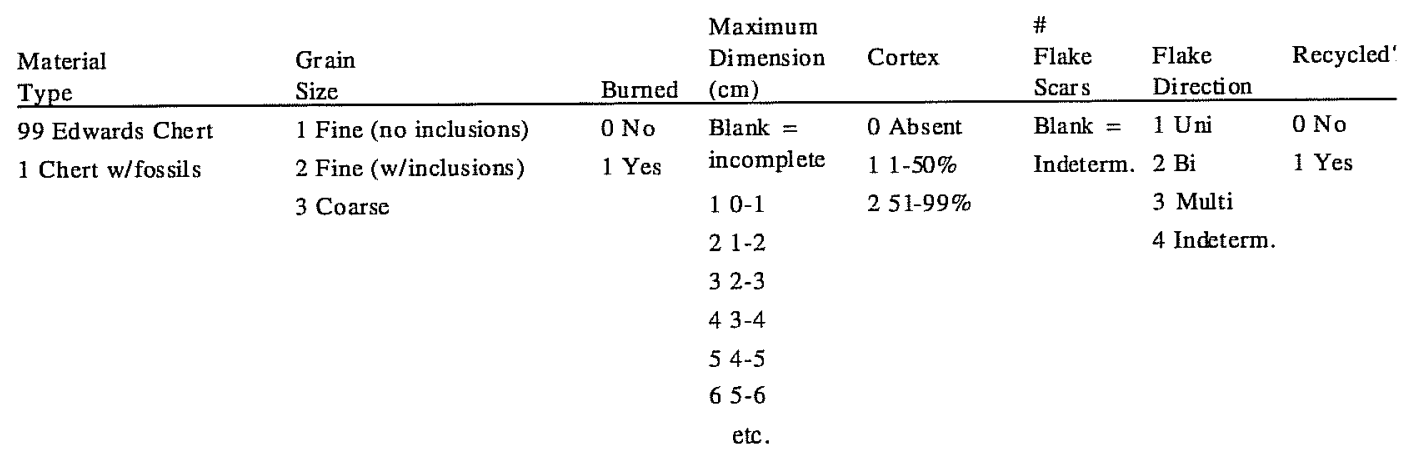


Table A-4. Debitage Attributes

\begin{tabular}{|c|c|c|c|c|c|c|c|c|c|}
\hline Bag \# & $\begin{array}{c}\text { Site } \\
\left(41 \mathrm{KE} \_-\right)\end{array}$ & $\begin{array}{c}\text { Collection } \\
\text { Unit }\end{array}$ & $\begin{array}{c}\text { Mate rial } \\
\text { Type }\end{array}$ & $\begin{array}{c}\text { Grain } \\
\text { Size }\end{array}$ & $\begin{array}{c}\text { Maximum } \\
\text { Dimension } \\
(\mathrm{cm})\end{array}$ & $\begin{array}{c}\# \\
\text { of } \\
\text { Facets }\end{array}$ & $\begin{array}{c}\text { Cortex } \\
\text { Amount }\end{array}$ & Type & $\begin{array}{c}\# \\
\text { Incomplete }\end{array}$ \\
\hline 1 & 41 & Site & 99 & 2 & 3 & 1 & 2 & 5 & \\
\hline 1 & 41 & Site & 99 & 1 & 4 & 3 & 2 & 5 & \\
\hline 1 & 41 & Site & 1 & 3 & 4 & 4 & 2 & 5 & \\
\hline 1 & 41 & Site & 99 & 1 & 3 & 3 & 2 & 5 & \\
\hline 1 & 41 & Site & 99 & 1 & 3 & 2 & 1 & 5 & \\
\hline 1 & 41 & Site & 1 & 2 & 5 & 4 & 2 & 7 & \\
\hline 1 & 41 & Site & 99 & 3 & 5 & 4 & 1 & 5 & \\
\hline 1 & 41 & Site & 30 & 2 & 5 & 4 & 1 & 5 & \\
\hline 1 & 41 & Site & 30 & 3 & 7 & 4 & 1 & 5 & 23 \\
\hline 1 & 41 & Site & 99 & 1 & 3 & 4 & 1 & 5 & \\
\hline 1 & 41 & Site & 99 & 1 & 2 & 4 & 1 & 5 & \\
\hline 1 & 41 & Site & 29 & 3 & 3 & 4 & 1 & 5 & \\
\hline 1 & 41 & Site & 99 & 1 & 2 & 3 & 3 & 5 & \\
\hline 1 & 41 & Site & 1 & 3 & 4 & 4 & 1 & 5 & \\
\hline 1 & 41 & Site & 99 & 1 & 2 & 3 & 3 & 5 & \\
\hline 1 & 41 & Site & 30 & 3 & 6 & 4 & 1 & 5 & \\
\hline 1 & 41 & Site & 99 & 3 & 4 & 2 & 3 & 5 & \\
\hline 1 & 41 & Site & 63 & 3 & 6 & 4 & 1 & 5 & \\
\hline 1 & 41 & Site & 7 & 3 & 3 & 4 & 1 & 5 & \\
\hline 3 & 41 & $5 \times 5 \mathrm{~m}$ & 99 & 1 & 4 & 1 & 2 & 5 & 4 \\
\hline 3 & 41 & $5 \times 5 \mathrm{~m}$ & 99 & 1 & 4 & 1 & 2 & 5 & 2 \\
\hline 1 & 42 & Site & 99 & 3 & 4 & 4 & 2 & 5 & \\
\hline 1 & 42 & Site & 99 & 1 & 5 & 3 & 2 & 5 & \\
\hline 1 & 42 & Site & 99 & 2 & 5 & 1 & 2 & 5 & \\
\hline 1 & 42 & Site & 99 & 1 & 3 & 1 & 2 & 5 & \\
\hline 1 & 42 & Site & 99 & 3 & 5 & 4 & 1 & 5 & \\
\hline 1 & 42 & Site & 99 & 3 & 5 & 1 & 1 & 5 & \\
\hline 2 & 42 & $5 \times 5 \mathrm{~m}$ & 99 & 3 & 4 & 2 & 2 & 5 & \\
\hline 2 & 42 & $5 \times 5 \mathrm{~m}$ & 99 & 2 & 5 & 4 & 2 & 5 & 2 \\
\hline 2 & 42 & $5 \times 5 \mathrm{~m}$ & 99 & 1 & 2 & 3 & 3 & 1 & \\
\hline 2 & 42 & $5 \times 5 \mathrm{~m}$ & 99 & 1 & 3 & 2 & 3 & 1 & \\
\hline 2 & 43 & SW Quad & 99 & 3 & 4 & 2 & 2 & 5 & \\
\hline 2 & 43 & SW Quad & 99 & 2 & 2 & 3 & 3 & 5 & \\
\hline 2 & 43 & SE Quad & 99 & 3 & 3 & 2 & 3 & 1 & 4 \\
\hline 2 & 43 & SE Quad & 99 & 1 & 4 & 4 & 1 & 5 & \\
\hline 2 & 43 & SW Quad & 99 & 3 & 4 & 2 & 2 & 5 & \\
\hline 2 & 43 & SW Quad & 99 & 3 & 4 & 4 & 1 & 5 & 4 \\
\hline 2 & 43 & SW Quad & 99 & 1 & 5 & 4 & 1 & 5 & \\
\hline 2 & 43 & SE Quad & 99 & 1 & 2 & 4 & 1 & 5 & \\
\hline 2 & 43 & SW Quad & 1 & 3 & 5 & 4 & 2 & 5 & 8 \\
\hline 2 & 43 & SE Quad & 99 & 2 & 5 & 2 & 2 & 5 & \\
\hline 2 & 43 & SW Quad & 99 & 1 & 3 & 3 & 3 & 1 & \\
\hline 2 & 43 & SW Quad & 99 & 3 & 3 & 1 & 1 & 5 & \\
\hline 2 & 43 & SE Quad & 99 & 3 & 4 & 1 & 3 & 5 & \\
\hline 3 & 43 & NE Quad & 99 & 2 & 3 & 1 & 3 & 5 & \\
\hline 4 & 43 & Site & 99 & 1 & 4 & 2 & 2 & 5 & 8 \\
\hline 8 & 43 & $5 \times 5 \mathrm{~m}$ & 99 & 3 & 4 & 4 & 1 & 5 & \\
\hline
\end{tabular}


Table A-4. continued

\begin{tabular}{|c|c|c|c|c|c|c|c|c|c|}
\hline Bag \# & $\begin{array}{c}\text { Site } \\
\left(41 \mathrm{KE} \_\right)\end{array}$ & $\begin{array}{c}\text { Collection } \\
\text { Unit }\end{array}$ & $\begin{array}{c}\text { Material } \\
\text { Type }\end{array}$ & $\begin{array}{c}\text { Grain } \\
\text { Size } \\
\end{array}$ & $\begin{array}{c}\text { Maximum } \\
\text { Dimension } \\
(\mathbf{c m})\end{array}$ & $\begin{array}{c}\# \\
\text { of } \\
\text { Facets }\end{array}$ & $\begin{array}{c}\text { Cortex } \\
\text { Amount } \\
\end{array}$ & Type & $\begin{array}{c}\# \\
\text { Incomplete }\end{array}$ \\
\hline 8 & 43 & $5 \times 5 \mathrm{~m}$ & 99 & 3 & 4 & 1 & 3 & 5 & \\
\hline 8 & 43 & $5 \times 5 \mathrm{~m}$ & 99 & 3 & 4 & 3 & 2 & 5 & \\
\hline 8 & 43 & $5 \times 5 \mathrm{~m}$ & 99 & 2 & 5 & 1 & 2 & 5 & 7 \\
\hline 11 & 43 & Site & 2 & 2 & 6 & 1 & 2 & 5 & 10 \\
\hline 2 & 44 & SE Quad & 1 & 2 & 5 & 4 & 1 & 5 & \\
\hline 2 & 44 & SE Quad & 1 & 3 & 5 & 4 & 2 & 5 & \\
\hline 2 & 44 & SE Quad & 1 & 2 & 5 & 1 & 2 & 5 & 3 \\
\hline 4 & 44 & $5 \times 5 \mathrm{~m}$ & 1 & 3 & 7 & 2 & 1 & 5 & 6 \\
\hline 5 & 44 & NE Quad & 99 & 3 & 5 & 1 & 1 & 5 & \\
\hline 5 & 44 & NE Quad & 99 & 3 & 3 & 4 & 2 & 5 & 8 \\
\hline 5 & 44 & NE Quad & 99 & 3 & 4 & 1 & 1 & 5 & \\
\hline 6 & 44 & NW Quad & 1 & 3 & 5 & 1 & 2 & 5 & 4 \\
\hline 1 & 45 & SW Quad & 99 & 3 & 4 & 4 & 1 & 5 & \\
\hline 1 & 45 & Site & 99 & 2 & 3 & 1 & 2 & 5 & \\
\hline 1 & 45 & Site & 99 & 3 & 5 & 2 & 2 & 5 & \\
\hline 1 & 45 & SW Quad & 7 & 3 & 7 & 4 & 1 & 5 & 11 \\
\hline 1 & 45 & SW Quad & 99 & 3 & 5 & 1 & 1 & 5 & \\
\hline 6 & 45 & NE Quad & & & & & & & 3 \\
\hline 7 & 45 & NW Quad & 99 & 3 & 6 & 4 & 1 & 5 & \\
\hline 7 & 45 & NW Quad & 99 & 3 & 6 & 2 & 2 & 5 & \\
\hline 7 & 45 & NW Quad & 99 & 2 & 4 & 1 & 2 & 5 & \\
\hline 7 & 45 & NW Quad & 99 & 3 & 4 & 4 & 1 & 5 & 1 \\
\hline 8 & 45 & $5 \times 5 \mathrm{~m}$ & 99 & 3 & 9 & 2 & 2 & 5 & \\
\hline 9 & 45 & $5 \times 5 \mathrm{~m}$ & 99 & 3 & 6 & 1 & 2 & 5 & 3 \\
\hline 11 & 45 & $5 \times 5 \mathrm{~m}$ & 99 & 3 & 4 & 4 & 2 & 5 & \\
\hline 11 & 45 & $5 \times 5 \mathrm{~m}$ & 99 & 3 & 11 & 1 & 1 & 5 & \\
\hline 11 & 45 & $5 \times 5 \mathrm{~m}$ & 99 & 3 & 6 & 1 & 2 & 5 & \\
\hline & & & & Mean & 4.34 & & & & \\
\hline
\end{tabular}

\begin{tabular}{|c|c|c|c|c|c|}
\hline \multirow[b]{2}{*}{$\begin{array}{l}\text { Material } \\
\text { Type }\end{array}$} & \multicolumn{4}{|c|}{ Debitage Analysis Codes } & \multirow[b]{2}{*}{ Type } \\
\hline & $\begin{array}{l}\text { Grain } \\
\text { Size }\end{array}$ & $\begin{array}{l}\text { Max. } \\
\text { Dimens. }\end{array}$ & $\begin{array}{l}\text { Platform } \\
\text { Faceting }\end{array}$ & Cortex & \\
\hline \multirow{2}{*}{$\begin{array}{l}99 \text { Edwards } \\
\text { Chert }\end{array}$} & 1 Fine (no inclusions) & \multirow{2}{*}{$\begin{array}{l}\text { Blank = } \\
\text { incomp. }\end{array}$} & 0 Absent & 0 Absent & 1 Biface Mamufacture \\
\hline & 2 Fine (w/inclusions) & & 1 Single & $11-50 \%$ & 2 Biface thin/resharp. \\
\hline \multirow{7}{*}{$\begin{array}{l}1-98 \text { chert } \\
\text { w/fossils }\end{array}$} & 3 Coarse & & 2 Double & $251-99 \%$ & 3 Uniface manuf/resharp. \\
\hline & & & 3 Three + & & $4 \mathrm{Blade}$ \\
\hline & & & 4 Corticate & & 5 Platform/core prep. \\
\hline & & & & & 6 Notching \\
\hline & & & & & 7 Sequence \\
\hline & & & & & 8 Channel \\
\hline & & & & & 9 Indeterminate \\
\hline
\end{tabular}




\title{
Appendix B: Geoarchaeology of the Cibolo Creek Basin in South Central Kendall County
}

\author{
C. Britt Bousman and David L. Nickels
}

\section{Introduction}

The focus of the geoarchaeological investigation was the upper late Quaternary basin of Cibolo Creek. The objectives of the subsurface investigation were to identify ancient landforms, shifts in streambeds, and buried soil surfaces with a potential for preserving evidence of human occupation.

\section{Description of the Project Area}

Cibolo Creek originates from springs emanating out of the Edwards Limestone formation approximately $14.5 \mathrm{~km}$ west and $122 \mathrm{~m}$ above the project area; it then flows across the Glen Rose Limestone Formation along the western edge of the project area, and drops below the surface into the Edwards Aquifer at Gorgs Hole approximately $18 \mathrm{~km}$ downstream (Barnes 1983). Rapid stream runoffs over a sharp drop in elevation from its headwaters to the project area have left alluvium deposits within the limestone entrenched valleys during the late Quaternary. The northern portion of the project area is a large flat plowed field that appears to be a T1 terrace of Cibolo Creek.

\section{Methods}

We visited the site to determine the best placement for backhoe trenches. In addition to a visual inspection of the surface, USGS 7.5' quadrangle topographic maps, an aerial photo, a Bureau of Economic Geology Atlas sheet (Barnes 1983), and the Kendall County Soil Survey report (Dittemore and Hensell 1981) were used to place backhoe trenches and produce a geomorphic map of the project area (see Figure 2). The city of Boerne provided a backhoe with a 28 -inch bucket for two days of testing. Thirteen backhoe trenches (BHTs) were strategically placed to best reveal the changes in subsurface soils and sediments and potential areas of buried cultural material (see Figure 2). BHTs 1-6 were placed on the east side of the plowed field near the Cibolo Creek cutbank. BHT 7 was placed in the middle of the field, and BHTs 8 and 9 were placed on the west side of the plowed field. BHTs 11 and 13 were excavated on alluvial deposits of an intermittent drainage on the extreme south end of the project area, and BHT 12 was placed on a low alluvial bench adjacent to a small intermittent drainage in the middle of the project area. Trenching operations were monitored by the project geomorphologist and archaeologist. Soils and sediments in all trenches were described according to the standards and procedures of the Soil Survey Staff (1993), and the trenches backfilled. Selected trench profiles were photographed. In addition, a 9-m+ exposed cutbank along Cibolo Creek was examined, described from a distance, and photographed. The descriptions of the stratigraphy of the cutbank and each trench are presented in Tables B-1-B-14.

\section{Alluvial Stratigraphy}

The cutbank profile and the profiles of BHTs 1-5 show that Cibolo Creek eroded approximately four meters into limestone bedrock, but before this cycle of erosion it deposited a terrace directly on bedrock. The lower portion of this terrace is composed of alternating gravel and silt beds that form gravel- and sandinfilled channels with silt overbank facies. In the upper portion of this terrace deposit is a dispersed gravel cemented by calcium carbonate, and a soil has developed on the surface. In most BHTs the A-horizon of the soil is eroded because the surface is beveled by recent erosion by the modern stream channel, but in BHT 4 the A horizon is thick $(0-80 \mathrm{~cm})$ and indicates a fairly long period of development.

BHT 6 is perpendicular to a small stream that was channelized. The sediments in this backhoe trench, especially those in zone 5, indicate that the small stream was depositing gravels, sand, and silt in overflow events. BHT 7 was placed in the center of the plowed field. The deposits recorded in this trench are 
extremely similar to those in BHTs $1-5$, indicating that the same geological unit was deposited at that location.

BHTs $8-10$ were excavated in the western portion of the plowed field in a low area, and the deposits were different from those in the previously discussed backhoe trenches. BHT 8 is in the far northwest portion of the field a few meters away from the toe slope of a limestone outcrop. The deposits in this backhoe trench consist of a much higher frequency of clay. The surface has been altered by pedogenesis and a single lithic artifact was found in the upper $10 \mathrm{~cm}$ within the plow zone. A buried weathering horizon was found between $100-155 \mathrm{~cm}$. In BHT 9, parallel with BHT 8 and at a slightly higher elevation, the upper deposits are very similar to those in the upper portion of BHT 8, but at approximately $80 \mathrm{~cm}$ the deposits become more coarse-grained. A similar pattern occurs in BHT 10 at the southwestern corner of the plowed field. One possibility is that the deposits in BHT 8 and the upper portion of BHTs 9 and 10 are a fine-grained plug in an infilled stream channel that flowed across the western portion of the field.

BHTs 11 and 13 were excavated in fluvial deposits adjacent to the same intermittent stream in the far southern side of the project area. The deposits in these two backhoe trenches are very different. The deposits in BHT 11 are a thin apron of poorly sorted sediments that probably represent both fluvial and colluvial transportation. The deposits in BHT 13 are well-sorted clay loams that have weathered to form a well-developed thick surface soil. BHT 13 is at the same approximate elevation as the backhoe trenches in the plowed field adjacent to the Cibolo Creek cutback, thus it is possible that the clayey deposits in BHT 13 are contemporary with the $\mathrm{T} 1$ terrace deposits in the plowed field. The deposits in BHT 12, on a low bench adjacent to a small intermittent stream, consist of gravels in the lower portion of the section and grade up to poorly sorted sediments in the upper portion of the section. Sediments in the upper portion of BHT 12 could have fluvial and colluvial contributions.

\section{Summary}

The deposits in the plowed field appear to represent a perched $\mathrm{T} 1$ terrace with an infilled paleochannel in the western portion of the project area. A relic of this terrace may still exist in the far southwestern portion of the project area at BHT 13. Alluvial sediments in the remaining portion of the project area are associated with intermittent streams and probably contain fluvial and colluvial components. It is difficult to estimate the ages of these deposits, but the perched T1 terrace could easily be early Holocene or older in age. 
Table B-1. Sediment Description for Cutbank 1

\begin{tabular}{ccl}
\hline Zone & Depth $(\mathrm{cm})$ & \multicolumn{1}{c}{ Description } \\
\hline 1 & $0-110$ & see Zones 1-8 in BHT 4 \\
\hline 2 & $110-140$ & $\begin{array}{l}\text { dispersed gravels at or near a discontinuous } \mathrm{CaCO}^{3} \text { cemented } \\
\text { ledge }\end{array}$ \\
\hline 3 & $140-270$ & see Zone 8 in BHT 4 \\
\hline 4 & $270-440$ & $\begin{array}{l}\text { gravel filled channel deposit that interfaces with yellow silt } \\
\text { laterally }\end{array}$ \\
\hline 5 & $440-460$ & yellow silt \\
\hline 6 & $460-480$ & gravel lenses \\
\hline 7 & $480-510$ & yellow silt \\
\hline 8 & $510-590$ & gravel lenses \\
\hline 9 & $590-1000$ & $\begin{array}{l}\text { Bedrock, entrenched by stream erosion, stream is 10m below } \\
\text { surface }\end{array}$ \\
\hline
\end{tabular}


Table B-2. Sediment Description for BHT 1

\begin{tabular}{|c|c|c|}
\hline Zone & Depth $(\mathrm{cm})$ & Descriptions \\
\hline 1 & $0-9$ & $\begin{array}{l}\text { dark brown (10YR } 3 / 3 \text { ) loam; friable granular weak; common small limestone } \\
\text { granules; few surface snails, moderate to heavy grass cover, common rootlets; } \\
\text { abrupt wavy lower boundary; Ap? }\end{array}$ \\
\hline 2 & $9-20$ & $\begin{array}{l}\text { very dark greyish brown }(10 \text { YR } 3 / 2) \text { silt loam, slightly more clayey than above; } \\
\text { friable medium weak; subangular blocky; common small limestone granules, } \\
\text { common rootlets, calcium carbonate caliche pebbles; clear smooth lower } \\
\text { boundary. }\end{array}$ \\
\hline 3 & $20-35$ & $\begin{array}{l}\text { very dark grayish brown (10YR } 3 / 2 \text { ) silt loam; friable medium weak; subangular } \\
\text { blocky; common small limestone granules, calcium carbonate caliche pebbles, } \\
\text { common rootlets, few roots, common calcium carbonate filaments and thin films } \\
\text { on ped faces, few worm casts; smooth clear lower boundary. }\end{array}$ \\
\hline 4 & $35-49$ & $\begin{array}{l}\text { dark brown (10YR 3/2) silt loam; friable, granular, fine; common slightly larger } \\
\text { limestone granules, common rootlets, few roots, few rounded limestone pebbles, } \\
\text { common calcium carbonate filaments and films on ped faces; abrupt irregular } \\
\text { lower boundary. }\end{array}$ \\
\hline 5 & $49-56$ & $\begin{array}{l}\text { yellowish brown ( } 10 \text { YR } 5 / 4 \text { ) silt loam; very fine to weak; subangular blocky; } \\
\text { common rounded to subangular limestone small cobbles and pebbles, common } \\
\text { calcium carbonate filaments and films on ped faces; clear wavy lower boundary. }\end{array}$ \\
\hline 6 & $56-68$ & $\begin{array}{l}\text { yellowish brown (10YR 5/6) silt loam; fine moderate granular; few subrounded } \\
\text { limestone pebbles, few small calcium carbonate nodules, common calcium } \\
\text { carbonate filaments and film on ped faces; clear wavy lower boundary. }\end{array}$ \\
\hline 7 & $68-85$ & $\begin{array}{l}\text { light yellowish brown (10YR 6/4) silt; slightly firm; abundant calcium carbonate } \\
\text { films on ped faces, few shattered nodules; unit fairly well cemented with calcium } \\
\text { carbonate; abrupt irregular lower boundary. }\end{array}$ \\
\hline 8 & $85-125$ & $\begin{array}{l}\text { very pale brown }(10 \mathrm{YR} 8 / 3) \text { hard cemented calcium carbonate; extremely firm } \\
\text { upper } 7 \mathrm{~cm} \text {; rare roots, rare limestone pebbles; abrupt irregular lower boundary. }\end{array}$ \\
\hline 9 & $125-155+$ & $\begin{array}{l}\text { very pale brown (10YR } 8 / 3 \text { ) silt; very firm; moderate medium subangular } \\
\text { blocky; common fine distinct (yellow [10YR } 8 / 3] \text { ) mottled, few limestone } \\
\text { pebbles, few caliche pebbles, common calcium carbonate cementation; lower } \\
\text { boundary not observed. }\end{array}$ \\
\hline
\end{tabular}



Table B-3. Sediment Description for BHT 2

\begin{tabular}{|c|c|c|}
\hline Zone & Depth $(\mathrm{cm})$ & Description. \\
\hline 1 & $0-10$ & $\begin{array}{l}\text { dark brown (10YR } 3 / 3 \text { ) loam; friable granular weak; common small } \\
\text { limestone granules; few surface snails, moderate to heavy grass cover, } \\
\text { common rootlets; abrupt wavy lower boundary; Ap? }\end{array}$ \\
\hline 2 & $10-29$ & $\begin{array}{l}\text { very dark greyish brown (10YR } 3 / 2 \text { ) silt loam, slightly more clayey than } \\
\text { above; friable medium weak; subangular blocky; common small } \\
\text { limestone granules, common rootlets, calcium carbonate caliche pebbles; } \\
\text { clear smooth lower boundary. }\end{array}$ \\
\hline 3 & $29-38$ & $\begin{array}{l}\text { dark brown (10YR } 3 / 2) \text { silt loam; friable, granular, fine; common } \\
\text { slightly larger limestone granules, common rootlets, few roots, few } \\
\text { rounded limestone pebbles, common calcium carbonate filaments and } \\
\text { films on ped faces; abrupt irregular lower boundary. }\end{array}$ \\
\hline 4 & $38-74$ & $\begin{array}{l}\text { yellowish brown (10YR } 5 / 6) \text { silt loam; fine moderate granular; few } \\
\text { subrounded limestone pebbles, few small calcium carbonate nodules, } \\
\text { common calcium carbonate filaments and film on ped faces; clear wavy } \\
\text { lower boundary. }\end{array}$ \\
\hline 5 & $74-95+$ & $\begin{array}{l}\text { very pale brown (10YR 8/3) silt; very firm; moderate medium } \\
\text { subangular blocky; common fine distinct (yellow [10YR 8/3]) mottled, } \\
\text { few limestone pebbles, few caliche pebbles, common calcium carbonate } \\
\text { cementation; lower boundary not observed. }\end{array}$ \\
\hline
\end{tabular}

Table B-4. Sediment Description for BHT 3

\begin{tabular}{ccl}
\hline Zone & Depth (cm) & \multicolumn{1}{c}{ Description } \\
\hline 1 & $0-40$ & $\begin{array}{l}\text { very dark grayish brown (10YR 4/2) silty loam; friable; abundant limestone } \\
\text { granules, very small pebbles; gradual smooth lower boundary. }\end{array}$ \\
\hline 2 & $40-70+$ & $\begin{array}{l}\text { strong brown (7.5YR 4/6 to 5/6) silt loam; weak medium; subangular blocky; } \\
\text { scattered limestone pebbles throughout; cemented calcium carbonate observed } \\
\text { at 100 cm. }\end{array}$ \\
\hline
\end{tabular}



Table B-5. Sediment Description for BHT 4

\begin{tabular}{|c|c|c|}
\hline Zone & Depth (cm) & Description \\
\hline 1 & $0-8$ & $\begin{array}{l}\text { brownish yellow (10YR } 6 / 6 \text { ) and brown (10YR 4/3) loam; loose crumbly; dense } \\
\text { grass cover; abundant roots; abrupt irregular lower boundary; Ap. }\end{array}$ \\
\hline 2 & $8-20$ & $\begin{array}{l}\text { very dark greyish brown (10YR } 3 / 2 \text { ) silt loam; abundant small limestone } \\
\text { granules, abundant rootlets, few worm casts, } 1 \text { grub; clear smooth lower } \\
\text { boundary; Ap2. }\end{array}$ \\
\hline 3 & $20-35$ & $\begin{array}{l}\text { very dark greyish brown }(10 \text { YR } 3 / 2) \text { silt loam; calcium carbonate filaments; } \\
\text { very abrupt wavy to irregular lower boundary; Ap3. }\end{array}$ \\
\hline 4 & $35-37$ & $\begin{array}{l}\text { yellow (10YR } 7 / 6) \text { silt; irregular lens; calcium carbonate filaments; abrupt } \\
\text { irregular lower boundary; Ap4. }\end{array}$ \\
\hline 5 & $37-65$ & $\begin{array}{l}\text { very dark greyish brown (10YR } 3 / 2) \text { silt loam; firm; medium moderate to } \\
\text { subangular blocking; abundant limestone granules, common rootlets, few roots, } \\
\text { very common calcium carbonate filaments on ped faces; gradual smooth lower } \\
\text { boundary; A1. }\end{array}$ \\
\hline 6 & $65-80$ & $\begin{array}{l}\text { dark brown ( } 10 \mathrm{YR} 3 / 3) \text { silt loam; firm; medium moderate subangular blocky } \\
\text { structure; very common limestone granules and small pebbles, abundant calcium } \\
\text { carbonate filaments and film on ped faces, insect burrows; gradual smooth lower } \\
\text { boundary; B. }\end{array}$ \\
\hline 7 & $80-130$ & $\begin{array}{l}\text { brownish yellow (10YR 6/6) silt loam; firm; fine moderate angular blocky } \\
\text { structure; abundant limestone granules, rare scattered limestone pebbles, rare } \\
\text { rabdotus, calcium carbonate filaments and film on ped faces; abrupt irregular } \\
\text { lower boundary. }\end{array}$ \\
\hline 8 & $130-160+$ & $\begin{array}{l}\text { yellow (10YR } 7 / 6) \text { silt; matrix supported limestone pebble/gravel lens; calcium } \\
\text { carbonate filaments and film on ped faces; lower boundary not observed. }\end{array}$ \\
\hline
\end{tabular}

Table B-6. Sediment Description for BHT 5

\begin{tabular}{ccl}
\hline Zone & Depth (cm) & \\
\hline 1 & $0-10$ & $\begin{array}{l}\text { dark brown (10YR 3/3) loam; friable granular weak; common small limestone } \\
\text { granules; few surface snails, moderate to heavy grass cover, common rootlets; } \\
\text { abrupt wavy lower boundary; Ap? }\end{array}$ \\
\hline 2 & $10-30$ & $\begin{array}{l}\text { very dark greyish brown (10YR 3/2) silt loam, slightly more clayey than above; } \\
\text { friable medium weak; subangular blocky; common small limestone granules, } \\
\text { common rootlets, calcium carbonate caliche pebbles; clear smooth lower b }\end{array}$ \\
\hline 3 & $30-50$ & $\begin{array}{l}\text { dark brown (10YR 3/2) silt loam; friable, granular, fine; common slightly larger } \\
\text { limestone granules, common rootlets, few roots, few rounded limestone pebbles, } \\
\text { common calcium carbonate filaments and films on ped faces; abrupt irregular } \\
\text { lower boundary. }\end{array}$ \\
\hline 4 & $50-80+$ & $\begin{array}{l}\text { yellowish brown (10YR 5/4) silt loam; very fine to weak; subangular blocky; } \\
\text { common rounded to subangular limestone small cobbles and pebbles, common } \\
\text { calcium carbonate filaments and films on ped faces; clear wavy lower boundary. }\end{array}$ \\
& &
\end{tabular}


Table B-7. Sediment Description for BHT 6

\begin{tabular}{ccl}
\hline Zone & Depth $(\mathrm{cm})$ & \multicolumn{1}{c}{ Description } \\
\hline 1 & $0-25$ & $\begin{array}{l}\text { dark yellowish brown (10YR 4/4) silt loam; few small limestone granules, } \\
\text { common root hairs; gradual smooth lower boundary; Ap? }\end{array}$ \\
\hline 2 & $25-40$ & $\begin{array}{l}\text { dark yellowish brown (10YR 4/4) silt loam; common calcium carbonate } \\
\text { filaments, few rabdotus; clear smooth lower boundary. }\end{array}$ \\
\hline 3 & $40-115$ & $\begin{array}{l}\text { yellowish brown (10YR 5/6) silt loam; friable; few rootlets, common calcium } \\
\text { carbonate filaments, few rabdotus, few limestone pebbles; clear smooth lower } \\
\text { boundary. }\end{array}$ \\
\hline 4 & $115-130$ & $\begin{array}{l}\text { yellowish brown (10YR 5/6) silt loam; friable; few rabdotus, few worm casts, } \\
\text { significantly less calcium carbonate filaments and films; clear irregular lower } \\
\text { boundary. }\end{array}$ \\
\hline 5 & $130-153$ & $\begin{array}{l}\text { brownish yellow (10YR 6/6) silt with common matrix supported gravels; some } \\
\text { indistinct gravel lenses; gravels are sloping away from small channels at } \\
\text { approximately 25 degree angle; clear smooth lower boundary. }\end{array}$ \\
\hline 6 & $153-195+$ & $\begin{array}{l}\text { brown (10YR 5/3) with yellowish brown (10YR 5/6) clay loam; common matrix } \\
\text { supported limestone gravels, common limestone granules; lower boundary not } \\
\text { observed. }\end{array}$ \\
\hline
\end{tabular}

\section{Table B-8. Sediment Description for BHT 7}

\begin{tabular}{ccl}
\hline Zone & Depth $(\mathrm{cm})$ & \multicolumn{1}{c}{ Description } \\
\hline 1 & $0-45$ & $\begin{array}{l}\text { very dark greyish brown (10YR 3/2) silty loam; abundant limestone granules; } \\
\text { gradual smooth lower boundary. }\end{array}$ \\
\hline 2 & $45-105$ & $\begin{array}{l}\text { light yellowish brown (10YR 6/4) silt loam; friable; common calcium carbonate } \\
\text { filaments; gradual smooth lower boundaries. }\end{array}$ \\
\hline 3 & $105-140+$ & $\begin{array}{l}\text { very pale brown (10YR 7/4) silty loam; friable; dispersed calcium carbonate } \\
\text { nodules, few rounded limestone pebbles, common calcium carbonate filaments; } \\
\text { lower boundary not observed. }\end{array}$ \\
\hline
\end{tabular}


Table B-9. Sediment Description for BHT 8

\begin{tabular}{|c|c|c|}
\hline Zone & Depth $(\mathrm{cm})$ & Description \\
\hline 1 & $0-35$ & $\begin{array}{l}\text { very dark grey (10YR 3/1) silt y clay; common limestone granules, } 2 \text { artifacts } \\
\text { (collected), common rootlets; clear smooth lower boundary; Ap? }\end{array}$ \\
\hline 2 & $35-55$ & $\begin{array}{l}\text { brown (10YR 4/3) silty clay loam; fine moderate suban gular blocky; abundant } \\
\text { limestone granules, common rootlets, few roots, common limestone pebbles, few } \\
\text { limestone filaments and clay films; clear smooth lower boundary. }\end{array}$ \\
\hline 3 & $55-100$ & $\begin{array}{l}\text { brown (10YR } 5 / 3 \text { ) clay loam; medium moderate subangular blocky; weakly } \\
\text { developed slickenslides, thin clay observed on ped faces; common limestone } \\
\text { granules, scattered small }(1-3 \mathrm{~cm}) \text { pebbles, common soft to firm calcium } \\
\text { carbonate nodules, common small manganese particles; clear smooth lower } \\
\text { boundary. }\end{array}$ \\
\hline 4 & $100-155$ & $\begin{array}{l}\text { dark brown ( } 10 \mathrm{YR} 3 / 3 \text { ) clay loam, medium moderate subangular blocky } \\
\text { structure, common } \mathrm{CaCO} 3 \text { nodules, few manganese nodules, few roots, gradual } \\
\text { smooth lower boundary. }\end{array}$ \\
\hline 5 & $155-245+$ & $\begin{array}{l}\text { brown ( } 7.5 \mathrm{YR} 4 / 4) \text { clay loam, strong medium angular blocky structure with } \\
\text { slickensides, scattered } \mathrm{CaCO} 3 \text { nodules, few manganese nodules, scatter small } \\
\text { limestone pebbles in lower } 10 \mathrm{~cm} \text {, lower boundary not observed. }\end{array}$ \\
\hline
\end{tabular}

Table B-10. Sediment Description for BHT 9

\begin{tabular}{ccl}
\hline Zone & Depth $(\mathrm{cm})$ & \multicolumn{1}{c}{ Description } \\
\hline 1 & $0-35$ & $\begin{array}{l}\text { very dark grey (10YR 3/1) to a black (10YR 2/1) clay loam; common small } \\
\text { limestone granules; gradual smooth lower boundary. }\end{array}$ \\
\hline 2 & $35-60$ & $\begin{array}{l}\text { dark brown (10YR 3/3) clay loam; few medium faint dark yellowish brown } \\
\text { (10YR 4/6) mottles, common limestone granules, worm casts; gradual smooth } \\
\text { lower boundary. }\end{array}$ \\
\hline 3 & $60-80$ & $\begin{array}{l}\text { dark brown (10YR 4/3) clay loam; firmer than the zones above; common } \\
\text { limestone granules; gradual smooth lower boundary. }\end{array}$ \\
\hline 4 & $80-100$ & $\begin{array}{l}\text { dark yellowish brown (10YR 4/4) sandy clay loam; friable; few to common } \\
\text { calcium carbonate filaments; gradual smooth lower boundary. }\end{array}$ \\
\hline 5 & $100-130+$ & $\begin{array}{l}\text { yellowish brown (10YR 5/6) silty loam; friable; moderate fine to medium } \\
\text { subangular blocky; common to abundant calcium carbonate filaments, light films } \\
\text { on ped faces; lower boundary not observed. }\end{array}$ \\
\hline
\end{tabular}


Table B-11. Sediment Description for BHT 10

\begin{tabular}{ccl}
\hline Zone & Depth $(\mathrm{cm})$ & \multicolumn{1}{c}{ Description } \\
\hline 1 & $0-45$ & $\begin{array}{l}\text { very dark grey (10YR 3/1) clay loam; few limestone granules; gradual smooth } \\
\text { lower boundary. }\end{array}$ \\
\hline 2 & $45-85$ & $\begin{array}{l}\text { dark yellowish brown (10YR 4/4) clay loam, fine moderate to weak subangular } \\
\text { blocky, gradual smooth lower boundary. }\end{array}$ \\
\hline 3 & $85-100$ & $\begin{array}{l}\text { yellowish brown (10YR 5/6) loam; fine moderate subangular blocky; few } \\
\text { limestone filaments, scattered limestone pebbles; gradual smooth lower } \\
\text { boundary. }\end{array}$ \\
\hline 4 & $100-150+$ & $\begin{array}{l}\text { yellowish brown (10YR 5/4) loam; fine moderate subangular blocky; common } \\
\text { limestone filaments; lower boundary not observed. }\end{array}$ \\
\hline
\end{tabular}

Table B-12. Sediment Description for BHT 11

\begin{tabular}{ccl}
\hline Zone & Depth $(\mathrm{cm})$ & \multicolumn{1}{c}{ Description } \\
\hline 1 & $0-40$ & $\begin{array}{l}\text { very dark greyish brown (10YR 3/2) clay loam; common small limestone } \\
\text { granules; gradual smooth lower boundary. }\end{array}$ \\
\hline 2 & $40-65$ & $\begin{array}{l}\text { dark brown (10YR 3/3) clay loam; abundant limestone granules; abrupt sloping } \\
\text { lower boundary. }\end{array}$ \\
\hline 3 & $65-72$ & $\begin{array}{l}\text { dark brown (10YR 3/3) clay loam; very abundant limestone gravels; gradual } \\
\text { smooth lower boundary. }\end{array}$ \\
\hline 4 & $72-80+$ & $\begin{array}{l}\text { dark brown (10YR 3/3) clay loam; common limestone gravels, rare manganese } \\
\text { secretions; lower boundary not observed. }\end{array}$ \\
\hline
\end{tabular}

Table B-13. Sediment Description for BHT 12

\begin{tabular}{ccl}
\hline Zone & Depth (cm) & \multicolumn{1}{c}{ Description } \\
\hline 1 & $0-25$ & $\begin{array}{l}\text { very dark greyish brown (10YR 3/2) silty loam; abundant limestone granules, } \\
\text { common rootlets, few roots, some ant burrows; gradual smooth lower } \\
\text { boundaries. }\end{array}$ \\
\hline 2 & $25-50$ & $\begin{array}{l}\text { dark greyish brown (10YR 4/2) silty loam; medium weak subangular blocky; } \\
\text { common limestone granules, few rootlets, few roots, few calcium carbonate } \\
\text { filaments, small patches of film on ped faces; clear smooth lower boundary. }\end{array}$ \\
\hline 3 & $50-70$ & $\begin{array}{l}\text { dark brown (10YR 3/3) silty loam; abundant limestone granules, small pebbles, } \\
\text { few small cobbles, few rabdotus, few calcium carbonate filaments on small } \\
\text { patches on ped faces; abrupt smooth lower boundary. }\end{array}$ \\
\hline 4 & $70-110$ & limestone, gravels, small cobbles in class to supported matrix. \\
\hline 5 & $110-145+$ & limestone, cobbles, subrounded to boulders in class supported matrix. \\
\hline
\end{tabular}


Table B-14. Sediment Description for BHT 13

\begin{tabular}{ccl}
\hline Zone & Depth $(\mathrm{cm})$ & \multicolumn{1}{c}{ Description } \\
\hline 1 & $0-40$ & $\begin{array}{l}\text { black (10YR 2/1) clay loam; extremely weak coarse to medium subangular } \\
\text { blocky structure; common rootlets, few limestone pebbles, common small } \\
\text { limestone granules and pebbles; firm; gradual smooth lower boundary. }\end{array}$ \\
\hline 2 & $40-110$ & $\begin{array}{l}\text { very dark grey (10YR 3/1) clay loam; medium moderate subangular blocky } \\
\text { structure; common limestone granules, few pebbles; gradual smooth lower } \\
\text { boundary. }\end{array}$ \\
\hline 3 & $110-140+$ & $\begin{array}{l}\text { dark grey (5YR 4/1) clay; medium moderate subangular blocky, small } \\
\text { manganese accretions, calcium carbonate film on ped faces; lower boundary not } \\
\text { observed. }\end{array}$ \\
\hline
\end{tabular}

\section{References Cited}

Barnes, V. E.

1983 Geologic Atlas of Texas: San Antonio Sheet. Bureau of Economic Geology. The University of Texas at Austin.

Dittemore, W. H., and J. L. Hensell

1981 Soil Survey of Kendall County. Soil Conservation Service, U.S. Department of Agriculture, Washington, D.C.

\section{Soil Survey Staff}

1993 U. S. Department of Agriculture Handbook. Government Printing Office, Washington, D. C. 


\title{
Appendix C: Preliminary Report on Obsidian from 41KE146
}

\author{
Thomas R. Hester
}

The obsidian flake from 41KE146 was analyzed using nondestructive Precise Xray Fluorescence (PXRF; Giauque et al 1993) at the Livermore Berkeley National Laboratory. Trace element data clearly indicate that the specimen's geologic origin is the Cerro Toledo source in New Mexico. This source is sometimes referred to in the literature as "Valles Caldera" or "Obsidian Ridge" and is located in the Toledo volcanic caldera in the Jemez Mountains $56 \mathrm{~km}$ north of Santa $\mathrm{Fe}$, New Mexico. Cerro Toledo obsidian has been documented at a number of sources in Texas, principally in the north half of the state; however, specimens have also been documented from Bandera, Dimmit, and Val Verde counties (Hester et al 1991; Hester et 1998).

\section{References Cited}

Hester, T. R., F. Asaro, F. Stross, R. Giauque, and J. Bourbon

1998 Obsidian in Texas: Geological Sources and Archeological Interpretations. Manuscript submitted for publication.

Hester, T. R., F. Asaro, F. Stross, and R. Giauque

1991 Trace Element Analyses and Geologic Source Studies of Obsidian Artifacts from Arenosa Shelter, Val Verde County, Texas. In Papers on Lower Pecos Prehistory, edited by S. A. Turpin, pp. 191-198. Studies in Archeology 8. Texas Archeological Research Laboratory, The University of Texas at Austin. 